\title{
Synthetic and Naturally Occurring Heterocyclic Anticancer Compounds with Multiple Biological Targets
}

\author{
Richard Kwamla Amewu ${ }^{1}\left[\right.$, Patrick Opare Sakyi ${ }^{1,2}$, Dorcas Osei-Safo ${ }^{1}\left[\right.$ and Ivan Addae-Mensah ${ }^{1, *}$ \\ 1 Department of Chemistry, School of Physical and Mathematical Sciences, College of Basic and Applied \\ Sciences, University of Ghana, Legon, Accra P.O. Box LG 56, Ghana; ramewu@ug.edu.gh (R.K.A.); \\ opsakyi@st.ug.edu.gh (P.O.S.); dosei-safo@ug.edu.gh (D.O.-S.) \\ 2 Department of Chemical Sciences, School of Sciences, University of Energy and Natural Resources, \\ Sunyani P.O. Box 214, Ghana \\ * Correspondence: iaddae-mensah@ug.edu.gh; Tel.: +233-277-55-44-00
}

check for updates

Citation: Amewu, R.K.; Sakyi, P.O.; Osei-Safo, D.; Addae-Mensah, I. Synthetic and Naturally Occurring Heterocyclic Anticancer Compounds with Multiple Biological Targets. Molecules 2021, 26, 7134. https:// doi.org/10.3390/molecules26237134

Academic Editor: Brullo Chiara

Received: 25 October 2021

Accepted: 22 November 2021

Published: 25 November 2021

Publisher's Note: MDPI stays neutral with regard to jurisdictional claims in published maps and institutional affiliations.

Copyright: (c) 2021 by the authors. Licensee MDPI, Basel, Switzerland. This article is an open access article distributed under the terms and conditions of the Creative Commons Attribution (CC BY) license (https:// creativecommons.org/licenses/by/ $4.0 /)$.

\begin{abstract}
Cancer is a complex group of diseases initiated by abnormal cell division with the potential of spreading to other parts of the body. The advancement in the discoveries of omics and bio- and cheminformatics has led to the identification of drugs inhibiting putative targets including vascular endothelial growth factor (VEGF) family receptors, fibroblast growth factors (FGF), platelet derived growth factors (PDGF), epidermal growth factor (EGF), thymidine phosphorylase (TP), and neuropeptide Y4 (NY4), amongst others. Drug resistance, systemic toxicity, and drug ineffectiveness for various cancer chemo-treatments are widespread. Due to this, efficient therapeutic agents targeting two or more of the putative targets in different cancer cells are proposed as cutting edge treatments. Heterocyclic compounds, both synthetic and natural products, have, however, contributed immensely to chemotherapeutics for treatments of various diseases, but little is known about such compounds and their multimodal anticancer properties. A compendium of heterocyclic synthetic and natural product multitarget anticancer compounds, their $\mathrm{IC}_{50}$, and biological targets of inhibition are therefore presented in this review.
\end{abstract}

Keywords: homeostasis; metastasis; angiogenesis; apoptosis; vascularization; heterocyclic compounds; multiple biological targets

\section{Introduction}

Cancer is a complex group of diseases the onset of which is characterized by abnormal cell division with the potential of spreading to other parts of the body over time [1,2]. The abnormal cell differentiation is normally accompanied by drastic weight loss, prolonged cough, and abnormal lump growth [3]. The prevalence of cancer is spiraling globally. Currently, cancer ranks second as the leading cause of death worldwide and in the year 2020 alone, an estimated 19.3 million new cases with 10 million deaths were recorded [4]. These statistics translate into an annual death rate that is a little over $50 \%$ of the annual new cases. Cancers of the stomach, lung, breast, prostate/cervix, and colorectum have all been reported but the most frequently diagnosed are lung and breast cancers followed by prostate which occurs predominantly among the aging male population [5]. Sex and age have become of paramount importance in cancer susceptibility and treatment, and men are said to be more prone to infections than women [6,7].

Prior to cancer becoming metastatic, its spread is initiated by pro-angiogenic factors consisting of vascular endothelial growth factor (VEGF) receptors, fibroblast growth factor (FGF), platelet derived growth factors (PDGF), epidermal growth factor (EGF), thymidine phosphorylase (TP), neuropeptide Y4 (NY4), and platelet factor 4 (PF4), etc. [8,9]. Upon initiation, the survival of these cancer cells and their proliferation are dependent on the supply of oxygen, nutrients, and clearance of waste products [10,11]. All these processes are dependent on the sprouting of vascular networks. New blood vessels form through 
a process called angiogenesis [12]. In the absence of the vascular extension, cancer cells become necrotic or undergo a process called apoptosis, limiting the proliferation rate [10]. The level of expression of necrotic or apoptotic factors is a reflection of the aggressiveness of a tumor $[13,14]$. Generally vascular development starts by basement membrane destruction which leads to the release of angiogenic factors. This activates endothelial cells to migrate which then proliferate and stabilize until a safeguard sets in $[10,15,16]$. Regulation of neoplastic vascularization as an important step in limiting cancer proliferation has received immense attention and extensive research [8,12]. To starve these tumor cells, cautious targeting of vessel sprouting activators with a foreknowledge of how they control this chemical signal is crucial in maintaining homeostasis [17,18].

Numerous cancer targets including VEGF, FGF, PGF, EGF, PDGF, topoisomerase I and II, histone deacetylase, tyrosine kinase, and transforming growth factor-alpha (TGF- $\alpha$, ) have been elucidated with multiple studies focused mainly on targeting the initiator VEGF [1,19-21]. However, halting VEGF signaling has not been very effective as reports of disease progression after treatment have become rampant [22].

A number of heterocyclic anticancer agents both synthetic and naturally occurring are in use and more are still being sought after [23-26]. Some examples are as shown in Figure 1. Heterocyclic compounds (ring compounds containing $\mathrm{C}$ and any of the atoms $\mathrm{N}, \mathrm{O}$, and $\mathrm{S}$ ) have been explored for their medicinal properties for the treatment of various diseases including cancer. Introduction of these heteroatoms improves solubility, polarity, and hydrogen bonding abilities leading to ADMET (Adsorption, Distribution, Metabolism, Excretion, and Toxicity) optimization of druggable candidates. Therapeutic heterocyclic agents such as 5 - fluorouracil 1 , orlistat 2 , vandetanib 3 , rapamycin 4 , axitinib 5, sorafenib 6, epigallocatechin 7, doxorubicin 8, daunorubicin 9, and Taxol 10 (Figure 1) have demonstrated high inhibition against different types of cancer cells [27-29].
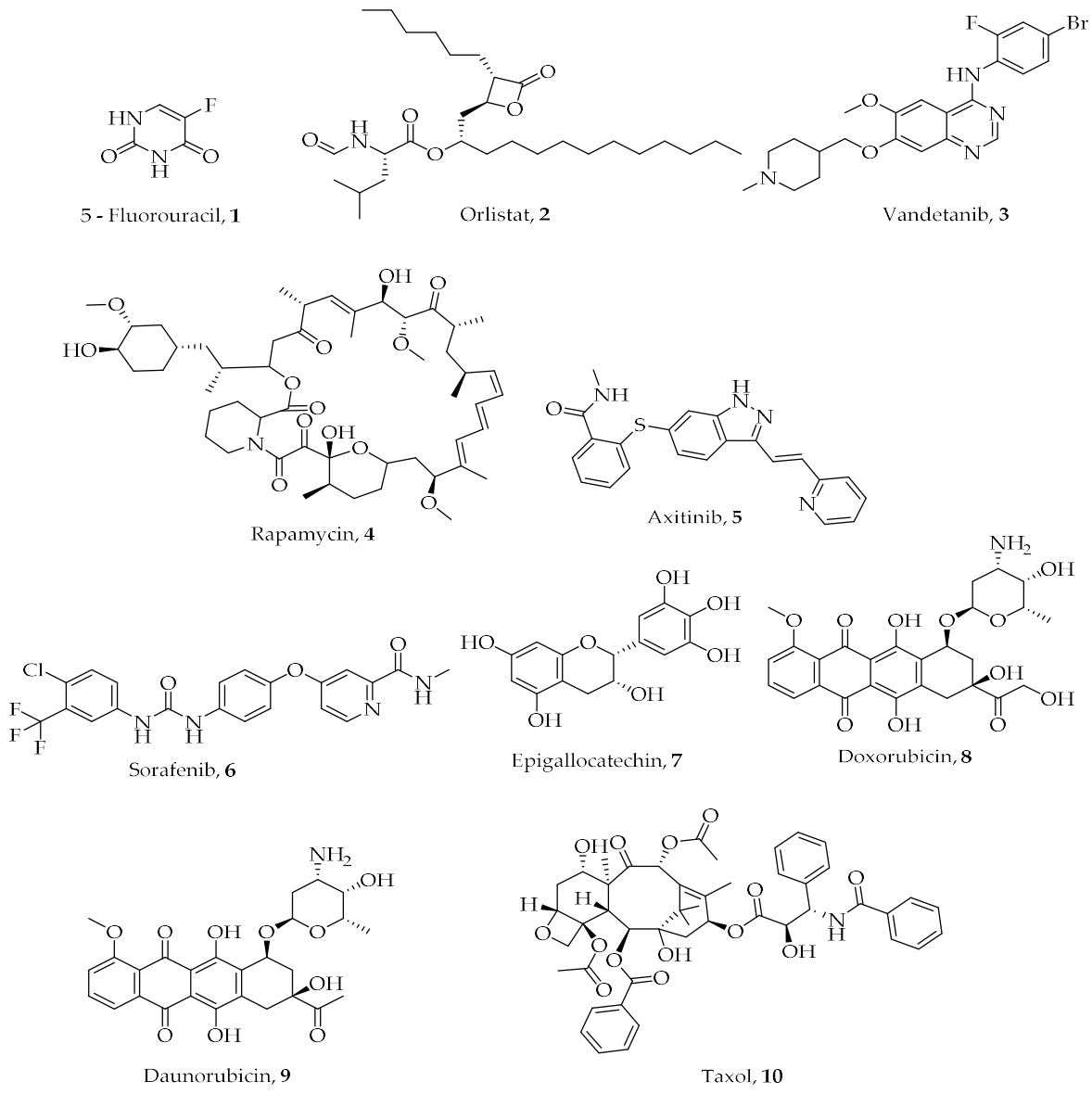

Figure 1. Chemical structures of some heterocyclic compounds used for treating various types of cancer. 
Brevilin A, 11, a heterocyclic sesquiterpene lactone natural product isolated from Centipeda minima exhibits anticancer properties [30]. Studies have shown that Brevilin A attenuates the signal transducer and activator of transcription (STATS 3) and Janus kinase and tyrosine kinase activity thereby inhibiting cell growth, inducing apoptosis and reducing cell metastasis [31]. Lee, Chan et al., synthesized analogues of Brevilin A and found that $\mathbf{1 3}$ and $\mathbf{1 4}$ exerted greater anticancer properties than $\mathbf{1 1}$. Aldol reaction of $\mathbf{1 1}$ and paraformaldehyde in the presence of sodium carbonate produced 12. Acetylation of $\mathbf{1 2}$ with $p$-nitrobenzoyl chloride and methacrylic anhydride afforded $\mathbf{1 3}$ and 14, respectively (Scheme 1) [26].

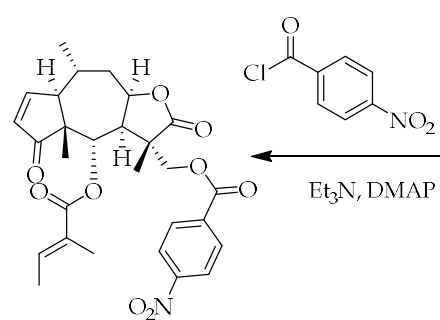

13
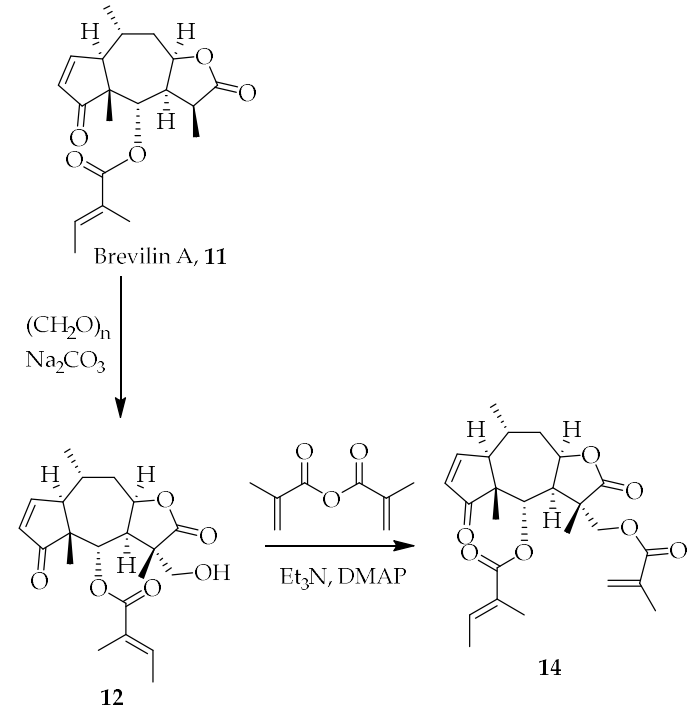

14

Scheme 1. Synthetic routes of Brevilin A analogues [26].

Challenges associated with cancer treatments such as drug resistance, systemic toxicity of administered drugs, and drug ineffectiveness are widespread [32,33]. Furthermore, confounding factors such as the multiple signaling nature of pathways and the propensity of most cancer cells to mutate have hindered the search for an effective therapeutic agent for combating cancers, calling for urgent search to identify new anticancer agents as drug leads [19,34]. To overcome these challenges, multi-target heterocyclic inhibitors are proposed as an option in achieving success in the fight against various forms of cancers.

Emerging heterocyclic compounds with demonstrable anticancer activities include sunitinib 15, midostaurin 16, and vorinostat 17 (Figure 2). They possess multi-regulatory activity against growth factors like vascular endothelium growth factor receptor (VEGFR), platelet-derived growth factor receptor alpha (PDGFRA's c-Kit) and tyrosine kinase 3 (FLT-3) [35]. In the same vein, gefitinib 18, erlotinib 19, lapatinib 20, and sotagliflozin 21 (Figure 2) with magnificent inhibitory potentials against human epidermal growth factor receptor 1 (HER1) and 2 (HER2) are also in phase 3 clinical trials confirming that multi-targeted therapy has a future $[36,37]$.

This review therefore seeks to highlight the various types of heterocyclic multimodality anticancer agents (synthetic and natural products) and their biological targets with some emphasis on their mechanism of action. Various systematic rigorous methodological approaches were used to search literature to identify, collate, and critically appraise a body of previously published works relevant to the topic. The search comprised of putting relevant key words into Scifinder, Scopus, Google scholar, PubMed, and others and appraising them for their suitability. Original hard copy offprints of published papers in our various personal archives were also consulted for relevant information [38,39]. 
<smiles>CCN(CC)CCNC(=O)c1c(C)[nH]c(C=C2C(=O)Nc3ccc(F)cc32)c1C</smiles>

Sunitinib, 15<smiles>CO[C@H]1[C@@H](N(C)C(=O)c2ccccc2)C[C@H]2O[C@]1(C)n1c3ccccc3c3c4c(c5c6ccccc6n2c5c31)C(=O)NC4</smiles>

Midostaurin, 16<smiles>COc1ccccc1OCCCCCCC(=O)NO</smiles>

Vorinostat, 17<smiles>COc1cc2ncnc(Nc3ccc(F)c(Cl)c3)c2cc1OCCCN1CCOCC1</smiles>

Gefitinib, 18<smiles>C#Cc1cccc(Nc2ncnc3cc(OCCOC)c(OCCOC)cc23)c1</smiles>

Erlotinib, 19<smiles>CS(=O)(=O)CCNCc1ccc(-c2ccc3ncnc(Nc4ccc(OCc5cccc(F)c5)c(Cl)c4)c3c2)o1</smiles>

Lapatinib, 20<smiles>CCOc1ccc(Cc2cc([C@@H]3O[C@H](SC)[C@@H](O)[C@H](O)[C@H]3O)ccc2Cl)cc1</smiles>

Sotagliflozin, 21

Figure 2. Chemical structures of some heterocyclic multi-target anticancer agents. Compounds 15-17 are in clinical use while 18-21 are in various stages of clinical trials.

\section{Heterocyclic Compounds}

Heterocyclic organic compounds are designated as integral components on a wide array of structures with both pharmacological and biological importance. They constitute a large cohort of structures with immense importance in the life sciences. Their diverse characteristics include the display of a wide variety of intermolecular interactions, different ring sizes, their planarity if aromatic, and functional group versatility. Among the twenty amino acids, proline, histidine, and tryptophan contain heterocyclic rings. Furthermore, the basic units that contain instructions for development, growth, and reproduction are all made of a heterocyclic nucleus.

Many natural products such as alkaloids, flavonoids, terpenoids, coumarins, anthocyanins, isothiazoles, etc., contain heterocyclic rings, possess a broad spectrum of activities against numerous disease-causing organisms. In addition, recent structural assessment of heterocyclic moieties among synthetic compounds by Marson has revealed that their incorporation plays a very significant role in drug-likeness and target binding by limiting toxic metabolite production, increasing water solubility, and lowering conformational entropy [40]. Heterocyclic chemotypes like quinoline, quinazoline, quinoxaline, pyrimidine, pyrazoline, 1,2,4-triazole, imidazole, benzimidazole, isoxazoline, isoquinoline, pyrazole, and isoxazole (Figure 3) can be found in compounds used in the treatment of debilitating diseases like malaria, tuberculosis, cancer, neuro-degenerative diseases, fungal, and bacterial infections [41-43]. The following are heterocyclic compounds that, if present as moieties in synthetic or naturally occurring compounds, may confer anti-cancer properties. 
<smiles>c1ccc2ncccc2c1</smiles>

quinoline<smiles>c1ccc2ncncc2c1</smiles>

quinazoline<smiles>c1ccc2nccnc2c1</smiles>

quinoxaline<smiles>c1cncnc1</smiles>

pyrimidine<smiles>C1CCSC1</smiles>

thiolane<smiles>C1=NCCN1</smiles><smiles>c1cn[nH]c1</smiles>

pyrazoline

pyrazole<smiles>c1ccc2sccc2c1</smiles>

benzothiophene<smiles>C1=NOCC1</smiles>

isoxazoline

\section{4,5-dihydro-1H-pyrazole}<smiles>C1CCSCC1</smiles>

thiane<smiles>c1cnoc1</smiles>

isoxazole<smiles>c1ncc2nc[nH]c2n1</smiles>

purine<smiles>c1ccc2c(c1)COS2</smiles>

$3 H$-benzo[c][1,2]oxathiole

Figure 3. Examples of heterocyclic chemotypes.

\subsection{N-Based Multi-Target Anticancer Heterocycles}

$\mathrm{N}$-based heterocyclic compounds have attracted much interest and attention from medicinal chemists and biologists. Their broad range of biological activities and wide applications in the design of drugs with exceptional selectivity for DNA via hydrogen bonding interaction has contributed to their high propensity for conferring anti-cancer properties on various synthetic and natural compounds in which they occur [44].

\subsubsection{Synthetic, Semi-Synthetic and Hybrid N-Heterocycles}

$\mathrm{N}$-based heterocycles such as $\mathbf{2 2}, \mathbf{2 3}$, and $\mathbf{2 4}$ (Figure 4) possess multi-target cancer inhibitory activity. They cause antagonism at $9.4 \mu \mathrm{M}$ (compound 22), $2.50 \mu \mathrm{M}$ (compound 23), and $9.30 \mu \mathrm{M}$ (compound 24) against topoisomerase 1. The compounds also antagonize kinase spindle protein (KSP) at 28.58, 8.91, and $19.47 \mu \mathrm{M}$, respectively [45]. Pathway analysis has suggested that the anticancer properties of the compounds are due to G1 apoptosis and cell cycle arrest at the $\mathrm{G} 2 / \mathrm{M}$ phase. It has further been observed that the selectivity and strong binding of the three compounds are partly due to the planarity of carboline and phenolic $\mathrm{OH}$ groups [45].

Additionally, cell studies of the combined histone deacylase (HDAC) inhibitors 25 and $\mathbf{2 6}$ with fluorouracil, an isosteric replacement for pyridine against HDAC protein source (Hela cell nuclear extract), resulted in inhibitory potentials of 5.92 and $2.31 \mu \mathrm{M}$ for compounds $\mathbf{2 5}$ and $\mathbf{2 6}$ compared to the moderate anti-proliferative activity estimated with seven tumor cell panels (K-562, A549, U266, PC-3, HCT-116, ES-2, and HL-7720) [46]. Discovery of the essential role of angiogenesis in tumor progression by Judah Folkman in the late 20th century has been recently supported by many genetic and epidemiological studies [47]. Similarly, a combination of deoxy-podophyllotoxin and 5-fluorouracil-yl showed an increased cytotoxic activity against tumor cell lines compared with the anticancer drugs VP-16 and 5-FU [48].

4-Deoxypodophyllotoxin-5-fluorouracil, 27, induced cell-cycle arrest in the G2/M phase by regulating levels of cdc2, cyclinB1, and p-cdc2 in A549 cells and migration of A549 cells via down-regulation of matrix metallopeptidase 9 (MMP-9) and up-regulation of tissue inhibitor of metalloproteinase (TIMP-1) [48]. A multi-target inhibitor is also formed by fusing vandetanib 3, a vascular endothelial growth factor receptor 2 (VEGFR2) inhibitor with Vorinostat, 17, an HDAC inhibitor. The fused product, 28 exhibited a very potent inhibitory activity against $\mathrm{HDAC}$ with an $\mathrm{IC}_{50}$ of $2.2 \mathrm{nM}$ and strong inhibitory effect against VEGFR-2 at $74 \mathrm{nM}$ [49]. Its inhibitory activity against a human breast cancer cell line MCF-7 
was at $\mathrm{IC}_{50}$ of $0.85 \mu \mathrm{M}$ [49]. Arylation of piperlongumine, an amide alkaloid present in Piper longum, Piper guineense and other Piper species, with combrestatin A4 afforded a potent semi-synthetic and hybrid compound KSS-9, 29, which exhibited increased reactive oxygen substrate (ROS) generation, tubulin depolymerization, and G2/M cell cycle phase block [50].<smiles>Cc1ccc(-n2c(S)nnc2-c2cc3c([nH]c4ccccc43)c(-c3cccc(O)c3)n2)cc1</smiles>

22

23<smiles>CSc1nnc(-c2cc3c([nH]c4ccccc43)c(-c3cccc(O)c3)n2)n1-c1ccc(C)cc1</smiles>

24<smiles>CCNC(=O)c1ccc(NC(=O)OCN2C=C(F)C(=O)CC2=O)cc1</smiles><smiles>COc1cc([C@H]2c3cc4c(cc3CC3COC(=O)[C@H]32)OCO4)cc(OC)c1OC(=O)NCCCCCCNC(=O)Cn1cc(F)c(=O)[nH]c1=O</smiles><smiles>COc1cc2ncnc(Nc3ccc(Br)cc3)c2cc1OCCCCCCC(=O)NO</smiles>

28<smiles>COc1ccc(/C(=C\c2cc(OC)c(OC)c(OC)c2)C(=O)N2CCC=CC2=O)cc1</smiles>

KSS-9, 29

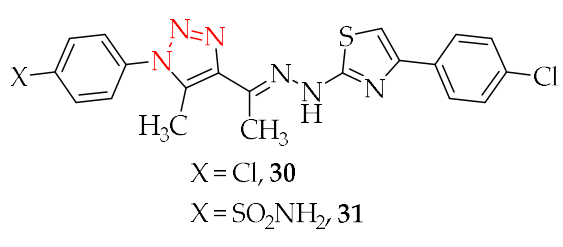<smiles>[Y][Y5](=O)O[Na]</smiles><smiles>Clc1ccc(Nc2nncc3ccccc23)cc1</smiles>

Vatalanib, 34<smiles>CN1CCN(c2nn3c(-c4cccc([N+](=O)[O-])c4)nnc3c3ccccc23)CC1</smiles>

35<smiles>CN1CCN(c2nn3c(-c4ccc([N+](=O)[O-])cc4)nnc3c3ccccc23)CC1</smiles>

36<smiles>CN1CCN(c2nn3c(-c4ccc(F)cc4)nnc3c3ccccc23)CC1</smiles>

37<smiles>CN1CCN(c2nn3c(C4CCCO4)nnc3c3ccccc23)CC1</smiles>

38

Figure 4. Examples of synthesized multi-target anticancer $\mathrm{N}$-based heterocyclic compounds.

The association between inflammation and tumor progression exemplified by inflammatory bowel diseases, bronchitis and prostatitis has reshaped the focus of many anticancer drug design programs from single targeting towards the use of multi-targetingdirected ligands. Of the seventeen nitrogen-containing heterocyclic compounds 22-38, four of them $(\mathbf{3 0}, \mathbf{3 1}, \mathbf{3 2}$, and 33) which are 1,2,3-triazole derivatives, were potent against cyclooxygenase-2 (COX-2) and 15-lypoxygenases (15-LOX) at sub-micromolar and micro molar concentrations, respectively, with only 31 and 33 showing activity against tumor associated carbonic anhydrase enzymes [51].

Despite the few pyridazines found in nature, recent demonstration of potency coupled with low toxicity have generated interest within the scientific community. An example is the VEGFR inhibitor vatalanib, 34, which is currently in clinical trials [52]. Investigating the effects of aryl group substitution on the 1,2,4-triazolo core, Romero and coworkers 
reported that four compounds 35-38 (Figure 4) exhibited good $\mathrm{IC}_{50}$ activities against breast cancer cells below $12 \mu \mathrm{M}$ [53]. In contrast to the breast cancer cell lines, lung carcinoma cells A549 were resistant with only 35, 36, and 38 being moderately cytotoxic (13.98 to $20.40 \mu \mathrm{M})$. However, 36 and 37 exhibited moderate anticancer activities against breast MCF-7 and SKBr3 carcinomas with bioactivities of 5.55 (36) and $11.13 \mu \mathrm{M}$ (37) for MCF-7 and 5.85 (36) and $8.48 \mu \mathrm{M}$ (38) for SKBr3. While compound 35 showed moderate anticancer activity $(8.58 \mu \mathrm{M})$, compound 36 exhibited strong anticancer activity against HeLa cell line at $0.54 \mu \mathrm{M}$ [53]. Structural extrapolations identified 3-nitrosubstitution on the aryl ring to be the most convenient pharmacophore with strong affinity towards EGFR tyrosine kinase enzyme [53].

A number of biologically active molecules with imidazole and benzimidazole nuclei have been explored for their diverse therapeutic uses including, but not limited to anti-parasitic, antimicrobial, antiviral, anti-helminthic, anti-hypertensive, analgesic, antiinflammatory, anti-ulcer, antiallergic applications [54]. Romero-Castro et al., 2011 synthesized six novel 2-aryl-5(6)-nitro-1H-benzimidazole derivatives (39-44) (Figure 5) and observed that the cytotoxicity of these compounds against various cancer cells was enhanced by the introduction of a nitro group at position 2 or 3 of the phenyl ring [55]. Among the derivatives, compound 44 was the most cytotoxic agent against all the cancer cell lines displaying an $\mathrm{IC}_{50}$ less than $10 \mu \mathrm{M}$. Interestingly, the same compound 44 was less cytotoxic against the non-neoplastic HACAT cell line. The mode of action exhibited by these compounds involves growth suppression via PARP inhibition, attenuation of DNA replication followed by $S$ phase cell cycle arrest resulting in apoptosis [55]. Similarly, evaluation of the activity of the benzimidazole derivative 45 against Hep3B-SR and HuH7-SR cell lines revealed that at $25 \mu \mathrm{M}$, it exhibited potent antiproliferative effects on the two cell lines [56]. It perpetuates its mode of action by inhibiting AKT, STAT3, and PARP as well as downregulating Fas, at the cell surface [56].

In another study, novel amidino 2-substituted benzimidazole derivatives linked to 1,4-disubstituted 1,2,3-triazoles by phenoxy methyl or ethyl linkers were synthesized [57]. An in vitro antiproliferative screening of the series revealed that compounds 46 and 47 were the most potent against the cell lines displaying an $\mathrm{IC}_{50}$ in the micromolar range [57]. SAR study revealed that introduction of isopropyl and phenoxymethyl groups at C-5 of the benzimidazole ring enhanced the antitumor activity of the derivative. These novel compounds inhibited protein kinases including TGM2, CDK9, SK1, and p38 MAPK [57].

Benzimidazole-quinolinone is another class of $\mathrm{N}$-based heterocycles that has attracted a lot of interest from medicinal and synthetic organic chemists possibly due to the presence of benzimidazole and quinolinone moieties [58]. An in vitro study evaluated twenty novel benzimidazole-quinolinone derivatives against HepG2, SKOV3, NCl-H460, and BEL-7404 cancer cell lines as well as HL-7702 normal liver cell line [59]. Two of the compounds, 48 and 49 displayed strong potency against HepG2 and BEL-7404 cell lines with IC $_{50}$ values of 8.45 and $9.06 \mu \mathrm{M}$, respectively, by not only inhibiting CDK and PARP but also activating p53 protein, caspase-3 and 9 as well as upregulating of Bax [59].

Cinnamic acids are natural products known for their wide pharmacological activities [60]. Employing the pharmacophore-based design approach, a new hybrid 50 was synthesized from imidazole and cinnamic acid and its activity evaluated against lung and breast cancer cell lines [61]. In addition to inhibiting tubulin polymerization and arresting G2/M phase of the cell cycle, the compound displayed its cytotoxicity against all the cell lines with $\mathrm{IC}_{50}$ in the range of 0.25 to $1.5 \mu \mathrm{M}$ [61]. Using a similar approach, Li et al. synthesized a series of imidazole derivatives of dehydroabietic acid and found them to exhibit antitumor activities via cell cycle arrest at the $S$ phase, activation of intracellular ROS and decrease in mitochondrion potential leading to apoptosis [62]. Among the series, compound 51 exhibited the highest activity against MCF-7 $(0.87 \mu \mathrm{M})$, HeLa $(9.39 \mu \mathrm{M})$, and HepG2 cell lines $(8.31 \mu \mathrm{M})$ [62]. 
<smiles>[R]c1cc(-c2nc3cc([N+](=O)[O-])ccc3[nH]2)c([Y])c([R])c1[R]</smiles>

$\mathrm{R}_{1}=\mathrm{R}_{2}=\mathrm{R}_{3}=\mathrm{R}_{4}=\mathrm{H}, 39$

$\mathrm{R}_{1}=\mathrm{NO}_{2}, \mathrm{R}_{2}=\mathrm{R}_{3}=\mathrm{R}_{4}=\mathrm{H}, 40$

$\mathrm{R}_{1}=\mathrm{R}_{3}=\mathrm{R}_{4}=\mathrm{H}, \mathrm{R}_{2}=\mathrm{NO}_{2}, 41$

$\mathrm{R}_{1}=\mathrm{R}_{2}=\mathrm{R}_{4}=\mathrm{H}, \mathrm{R}_{3}=\mathrm{NO}_{2}, 42$

$\mathrm{R}_{1}=\mathrm{R}_{3}=\mathrm{H}, \mathrm{R}_{2}=\mathrm{R}_{4}=\mathrm{NO}_{2}, 43$

$\mathrm{R}_{1}=\mathrm{R}_{4}=\mathrm{H}, \mathrm{R}_{2}=\mathrm{NO}_{2}, \mathrm{R}_{3}=\mathrm{Cl}, 44$<smiles>CC(NC(=N)c1ccc2[nH]c(-c3ccc(OCc4cn(-c5ccc(Cl)cc5)nn4)cc3)nc2c1)c1cccc(/C=C/C(=O)c2nc3ccccc3n2CCN2CCCC2)c1</smiles>

45

46<smiles>Cl[NH+]1CCNC1c1ccc2[nH]c(-c3ccc(OCc4cn(Cc5ccccc5)nn4)cc3)nc2c1</smiles>

47<smiles>CCOc1ccccc1/C=C/C(=O)Nc1ccccc1-c1nc2cc(C)ccc2[nH]1</smiles>

50<smiles>Cn1cccc1-c1nc2cc(NC(=O)CCl)ccc2[nH]1</smiles>

53<smiles>CCCC(CC)[C@@](C)(CI)C(=O)OC</smiles>

51<smiles>[R]c1cc(-n2ccnc2-c2cc(OC)c(OC)c(OC)c2)ccc1OC</smiles>

$\mathrm{R}=\mathrm{NH}_{2}, 54$

$\mathrm{R}=\mathrm{OH}, 55$<smiles>O=c1[nH]c2c(cc1-c1nc3cc(Cl)ccc3[nH]1)=CC1OCCOC1C=2</smiles>

48<smiles>Cc1ccc(-c2nc3cc(NC(=O)CCl)ccc3[nH]2)cc1</smiles>

52<smiles>COc1cc(C(=O)c2[nH]c(-c3ccc(C)cc3)nc2C)cc(OC)c1OC</smiles>

56

Figure 5. Examples of synthesized imidazole and benzimidazole multi-target anticancer compounds.

Li et al., screened a cluster of benzimidazole compounds against receptor tyrosine kinase involved in vascular sprouting and found two novel inhibitors $\mathbf{5 2}$ and $\mathbf{5 3}$ with strong multi-targeting potentials against estimated glomerular filtration rate (EGFR), vascular endothelial growth factor (VEGFR) and platelet-derived growth factors (PDGFR) depicted by apoptosis and cell cycle arrest at G0/G1 stage [63]. Following their earlier success, they synthesized 1-substituted-2-arylimidazoles and tested them against seven cancer cell lines [64]. Of all the imidazoles synthesized, compound 54 exhibited the highest potency against all the cell lines with $\mathrm{IC}_{50}$ less than $200 \mathrm{nM}$ [64]. Interestingly, compound 55 with an $-\mathrm{OH}$ group instead of $-\mathrm{NH}_{2}$ as in compound 54 also showed good potency against HeLa and HCT-15 cell lines with IC 50 of 100 and $200 \mathrm{nM}$, respectively. When SAR was performed on the compounds, it was observed that while the addition of an aromatic ring on the imidazole ring improved the antiproliferative effects, the placement of an aliphatic group on the imidazole nitrogen and the replacement of the imidazole ring with an ester or amide caused a loss in activity [64]. The novel imidazole derivatives inhibit microtubules 
disrupting the formation of mitotic spindles which in turn causes cell cycle arrest and apoptotic cell death [64].

In an attempt to improve efficacy and overcome multidrug resistance, Bai et al. reported the imidazole derivatives 54,55 and $\mathbf{5 6}$. Compound 56 was similar to 54 , but had an electron withdrawing group (carbonyl group) attached to the imidazole ring [65]. They reported that compound $\mathbf{5 6}$ targeted tubulin and DNA by disrupting microtubule assembly, causing DNA damage, and inducing cell cycle arrest. In addition, 56 mediated ROS mitochondrial and apoptotic pathways with $\mathrm{IC}_{50}$ of 27.42, 23.12, and $33.14 \mathrm{nM}$ against SW480, HCT-116, and Caco2 cell lines, respectively [65].

Building on a bioactive ingredient (ligustrazine) from widely used Chinese herbs, Zha et al. profiled the potentials of thirty-two derivatized ligustrazine frameworks against five cancer cell types, namely, tubulin, EGFR, tyrosine receptor kinase (TRK), kafirin (KAF), and B-raf proto-oncogene (BRAF) [66]. Among the synthetic candidates only two, 57 and 58 (Figure 6), exhibited potency as multi-target anticancer inhibitors to Tubulin, EGFR, KAF and BRAF and tropomyosin receptor kinase (TRK) as well as modulators of multidrug regulators (MDR) [66].<smiles>Cc1nc(C)c(/C=C2\CN(C)C/C(=C\c3nc(C)c(C)nc3C)C2=NO)nc1C</smiles>

57<smiles>COc1nc(Br)c(/C=C2\CN(C)C/C(=C\c3nc(C)c(C)nc3C)C2=NO)nc1C</smiles>

58<smiles>COc1ccc(Oc2nc(Nc3ccc(N4CCCCC4)nc3)ncc2NC(=O)c2cc(OC)cc(OC)c2)cc1</smiles>

59<smiles></smiles>

60<smiles>Cc1ccc(F)c(NC(=O)Nc2ccc(-c3cccc4[nH]nc(N)c34)cc2)c1</smiles>

Linifanib, 61<smiles>Cc1cccc(NC(=O)Nc2ccc(-c3cc(C)nc4noc(N)c34)cc2)c1</smiles>

62<smiles>O=C(Nc1ccc(-c2ccc(NC(=O)C3CC3)nc2)cc1)Nc1cccc(C(F)(F)F)c1</smiles><smiles>O=C(Nc1ccc(-c2ccc(NC(=O)C3CC3)nc2)cc1)Nc1ccc(Cl)c(C(F)(F)Cl)c1</smiles>

64

Figure 6. Derivatives of ligustrazine (57,58), 5-amino-4-pyrimidinol (59), $N$-(2-aminophenyl) benzamide acridine (60), Linifanib (61) and its isoxazol[3,4-b]pyridine-3-amino-derivative 62, as well as other biphenyl-aryl urea derivative (63 and 64 ).

A demonstration of weak in vitro/in vivo activity by a hit compound is often exploited in the selection of an initial scaffold or starting material for the synthesis of improved bioactive compounds. Employing this approach, Farag et al. synthesized seven derivatives of 5-amino-4-pyrimidinol of which compound 59 showed broad spectrum anti-cancer activity, with the indicated percentage inhibitions of the following cancers: hematological $(84.1 \%)$, colon $(72,15 \%)$, CNS $(66.34 \%)$, melanoma $(66.48 \%)$, ovarian $(51.55 \%)$, renal $(55.95 \%)$, prostate $(61.85 \%)$, and breast $(60.87 \%)$ [67]. ( $N$-(2-aminophenyl) benzamide acridine is another chemotype whose derivatives have been found to show improved suicidal action on tumor cells [68]. However, of the eleven novel synthetic $N$-heterocyclic macrocyclic derivatives tested (Figure 6) only compound 60 possessed multi-targeting potential against HDAC (87 nM), transmembrane ligand-activated receptor tyrosine kinase (FLT3) (87 nM), 
and Janus kinase 2 (JAK2) $(0.68 \mu \mathrm{M})$, with a high cytotoxic effect on human acute myeloid leukemia cell line MV4-11 and human erythroleukemia (HEL) cells. Compound $\mathbf{6 0}$ acts by halting cell proliferation $\left(\mathrm{IC}_{50} 0.12-0.35 \mu \mathrm{M}\right)$ triggered by $\mathrm{G0} / \mathrm{G} 1$ cell cycle arrest and cellular apoptosis by inhibition of Topoisomerase 1 and HDAC [55].

( $\mathrm{N}$-(2-aminophenyl) benzamide acridine is another chemotype whose derivatives have been found to show improved suicidal action on tumor cells [68].

Receptor tyrosine kinases (RTK) plays a critical role in the development and progress of cancers. Its inhibition has been found to stop transformation, proliferation, migration, differentiation, and metastasis of cancer cells. To improve the efficacy of Abbott's Linifanib, $\mathbf{6 1}$ Shi et al. reported a diaryl-urea with isoxazol[3,4-b]pyridine-3-amino-derivative $\mathbf{6 2}$ with inhibition potentials of $4 \mathrm{nM}, 3 \mathrm{nM}$, and $8 \mathrm{nM}$ against fms related receptor tyrosine kinase 3 (FLT3), kinase insert domain receptor (KDR), and platelet-derived growth factor receptor beta (PDGFR- $\beta$ ), respectively $[69,70]$. In another study, Jinfeng Wang and co-workers discovered two triple inhibition chemotypes, 63 and 64 (Figure 6) from screening of these compounds derived from reaction between biphenyl-aryl urea and salicylaldoxime [71]. These two derivatives showed strong potency against pro-angiogenic receptors (VEGFR-2, tyrosine kinase 2 (TIE-2), and ephrin type B receptor (EphB4) resulting in the inhibition of endothelial cell survival, vascular permeability, migration, and proliferation [71].

\subsubsection{Natural Products from Various Sources}

The medicinal use of natural products dates to ancient times [72,73]. Currently, it is estimated that about $70 \%$ of new drugs for the treatment of infectious diseases originate directly or indirectly from natural products of both floral and faunal origins [74,75]. Over the years there have been several reviews on plants as real and potential sources of compounds and their use in the treatment of cancer. Prominent among these reviews is the proceedings of the 16th annual meeting of the Society for Economic Botany: 1975 [76]. Cancer treatment has benefited immensely from natural products. Prominent among these are the vinca alkaloids from Catharanthus roseus (Vinca rosea) used for the treatment of leukemia and Taxol from Taxus baccata that is used for the treatment of cervical cancer $[77,78]$. The search for multitarget anticancer compounds can therefore not be complete without considering natural products from plant, soil, marine, fungal, and animal sources.

\subsubsection{Nitrogen-Heterocyclic Natural Products with Multitarget Inhibitory Properties}

The properties of some natural products have also been harnessed in the search for improved anticancer activities (Figure 7), For example, berberine 65, isolated from Rhizoma Coptidis is a heterocyclic alkaloid known to have multi-targeting potentials against a myriad of human cancer receptors [79]. It suppresses growth of cholangiocarcinoma cell lines. This anticancer activity has been attributed to inhibitions of ERK1/2, NF-KB and STAT3 pathways. The compound also arrests the G1 cell cycle at $9.3 \mu \mathrm{M}$ concentration within $48 \mathrm{~h}$ and $3.0 \mu \mathrm{M}$ within $72 \mathrm{~h}$ [80]. Despite the DNA intercalation property of berberine $65 \mathrm{Lin}$ and co-workers evaluated it on N-acetyltransferase (NAT) suppression in HL-60 cells and observed no effects on its gene expression at $30 \mu \mathrm{M}$ [81].

Evodiamine, 66, isolated from Evodia rutaecarpa, has been described as a tumor inhibitor with multi-targeting profiles against Topoisomerase I and II. Though the in vitro activity was encouraging, it demonstrated low in vivo potency [82]. Xinglin Li and coworkers have reported improved in vivo antitumor activity in a series of novel boronincorporated derivatives of evodiamine 66 using HCT116, MCF-7, and A549 cell lines [83]. The N13 deprotected phenyl boronic acid derivative, $\mathbf{6 7}$ showed excellent antitumor activity in an HCT116 xenograft model in mice ( $\mathrm{IC}_{50}$ of $\left.16 \mathrm{nM}\right)$ disrupting the PI3K/AKT signaling pathway [83]. 
<smiles>COc1ccc2cc3[n+](cc2c1OC)CCc1cc2c(cc1-3)OCO2</smiles>

Berberine, 65<smiles>CN1c2ccccc2C(=O)N2CCc3c([nH]c4ccccc34)[C@]21C</smiles>

Evodiamine, 66<smiles>CN1c2ccc(F)cc2C(=O)N2CCc3c([nH]c4ccc(B5OC(C)(C)C(C)(C)O5)cc34)[C@H]21</smiles>

67<smiles>CCn1c2ccccc2c2c3c(c4c5ccccc5[nH]c4c21)C(=O)N(CO)C3=O</smiles>

ZWM026, 68

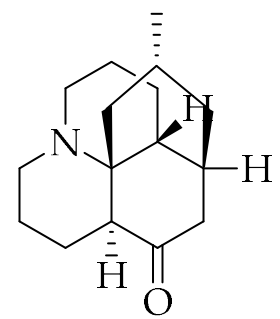

Lycopodine, 69<smiles>C=C[C@H]1C[C@H](C)C[C@H](C)[C@H]1c1c(O)ccn(O[C@@H]2C(C(=O)OC)=C[C@H](O)[C@H](O)[C@H]2O)c1=O</smiles>

Maximiscin, 70

Figure 7. $N$-heterocyclic natural product compounds with multi-target effects on cancer cells.

Some naturally occurring mangrove indolocarbazoles were investigated for their multiple kinase inhibition potential against non-small-cell lung cancer cells. Compound 68 demonstrated selectivity towards oncoproteins HER2 (IC $50190.7 \mathrm{nM}$ ), HER3 (IC 50 $160.3 \mathrm{nM})$, and HER4, (IC $50180.1 \mathrm{nM}$ ) [84]. It induced apoptosis and exerted a synergistic effect by combining with cisplatin in NCI- H1975 cells. It also potently and selectively inhibited growth of naturally occurring non-small-cell lung carcinoma (NSCLC) cells and constructed NIH-3T3 cells. Evaluation of the in vivo performance revealed that 68 inhibited EGFR-L858R/T790M with $\mathrm{IC}_{50}$ of $279.6 \mathrm{nM}$ and RET (IC $50183.7 \mathrm{nM}$ ) [84]. In addition to the potency of 68 against these targets, it also displayed downregulation of phosphor-Akt and phosphor-ERK [84].

Lycopodine, 69, the main alkaloid of Lycopodium clavatum extract was reported to have anticancer effect on HeLa cells through DNA damage, 5-LOX inhibition, G0/G1 cell cycle arrest, deactivation of oxidation resistance (OXR) receptor and mitochondrion membrane depolarization [85]. J. Robles and co-workers identified maximiscin $\mathbf{7 0}$ as possessing multitarget anticancer properties [86]. They investigated its activity against cancer cell lines in vitro and in a xenograft mouse model of melanoma and found that $\mathbf{7 0}$ inhibited proliferation of all of the following five triple-negative breast cancer cell lines at the stated $\mathrm{IC}_{50}$ values: MDA-MB-468 $(0.6 \mu \mathrm{M})$, MDA-MB-231 $(39 \mu \mathrm{M})$, MDA-MB-453 $(15 \mu \mathrm{M})$, HCC-70 $(60 \mu \mathrm{M})$, and BT-549 $(15 \mu \mathrm{M})$ [86]. It is suggested that the mechanism of action of the compound involves the induction of DNA damage as the primary suicidal action as well as activation of DNA damage response pathways and cell cycle arrest [86].

Didemnins are depsipeptides isolated from the sea squirt. They possess activity against various cancers including P388 lymphocytic leukemia and B16 melanoma [87]. Didemnin B, $\mathbf{7 1}$ is reported to target DNA functionality [88]. It perturbs cell-cycle and inhibits the synthesis of DNA at the elongation phase via the dual inhibition of palmitoylprotein thioesterase 1 (PPT1) and eukaryotic translation elongation factor-1 $\alpha$ (EEF1A1) [89]. It also activates caspases, thereby inducing apoptosis and inhibits protein synthesis by preventing eukaryotic elongation factor (Eef-2)-dependent translocation (Figure 8) [90]. 


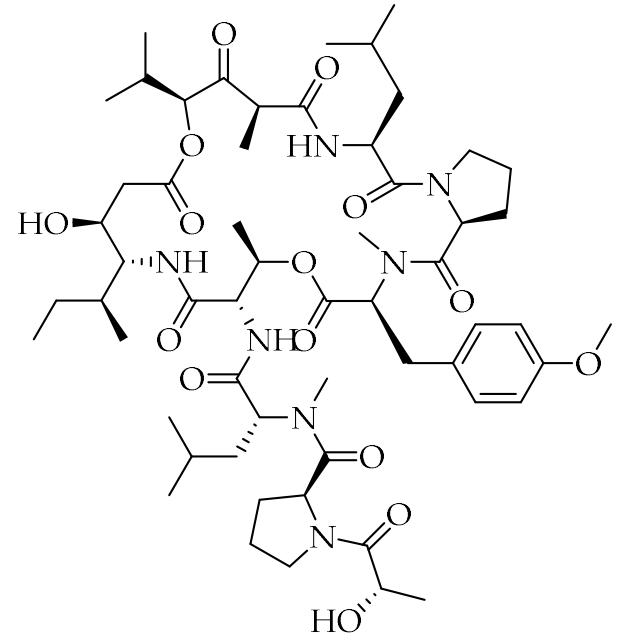

Didemnin B, 71<smiles>Cn1cnc(SSc2ncn(C)c2C[C@H](N)C(=O)O)c1C[C@H](N)C(=O)O</smiles>

Ovothiols, 72

$\begin{array}{ll}\text { Cancer: Colon } & \text { Cancer: Cervical } \\ \text { Cancer Cell: HCT116 } & \text { Cancer Cell: HeLa } \\ \text { Biological Target: PPT1 } & \text { Biological Target: EEF1A1 } \\ \mathrm{IC}_{50}=0.247 \mu \mathrm{M} & \end{array}$

Figure 8. Chemical structures of Didemnin B, 71 and Ovothiols, 72 with a summary of their biological activity towards selected targets.

Compound $\mathbf{7 2}$ is an example of a group of histidine-derived compounds called Ovothiols. These compounds are found in most members of the kingdom Protoctista (especially algae and protozoa) as well as many marine invertebrates including Paracentrotus lividus, Strongylocentrotus purpuratus, Arbacia lixula, Marthasterias glacialis, Astropecten aurantiacus, Octopus vulgaris, Loligo vulgaris and Platynereis dumerilii [91]. Compound 72 exhibits its anticancer properties by inhibiting autophagy initiation [92].

The microsclerodermins are cyclic hexapeptides from a deep-water sponge of the genus Microscleroderma [93]. They were first reported by Guzman et al., during their quest for small molecule inhibitors against nuclear factor kappa B (NF- $\mathrm{kB}$ ) cells [94]. Microsclerodermin $A, 73$ and $B, 74$ inhibit NF- $\kappa B$ transcriptional activity leading to reduction of levels of phosphorylated (active) NF- $\mathrm{KB}$ in the AsPC-1 cell line, against the AsPC-1, BxPC-3, MIA $\mathrm{PaCa}-2$ and PANC-1 pancreatic cancer cell lines, and induce significant apoptosis in the AsPC-1, BxPC-3 and the PANC-1 cell lines [94]. Subsequent investigation of the mechanism of action of $\mathbf{7 3}$ and $\mathbf{7 4}$ revealed that they also regulated the expression of proteins in the glycogen synthase kinase 3 pathway (Figure 9) [94].

Aaptamines, 75 are a group of bioactive benzo[de[1,6]]-naphthyridine alkaloids, isolated from marine sponges mostly belonging to the genus Aaptos [95]. Aaptamine, 75, possesses antioxidative, antimicrobial, antifungal, and antiretroviral activity. It is also reported to modulate AP-1, NF- $\mathrm{KB}$, and p53-dependent transcriptional activity in JB6 Cl41 cells (Figure 10) [96].

Neoechinulin A, $\mathbf{7 6}$ is from the marine fungal strains Microsporum sp and Aspergillus sp [97]. It consists of three structural moieties: an indole, a diketopiperazine and an isoprenyl group. Cytotoxicity tests of $\mathbf{7 6}$ on human cervical carcinoma HeLa cells showed it to express p53, p21, Bax, Bcl-2, Caspase 9, and Caspase 3 proteins [98]. Western blot analysis also revealed that 76 could induce cell apoptosis through down-regulation of Bcl-2 expression, up-regulation of Bax expression and activation of the caspase-3 pathway [97,98]. Compound $\mathbf{7 6}$ also suppressed the production of nitric oxide (NO) and prostaglandin E2 (PGE2) and the expression of inducible nitric oxide synthase (iNOS) and cyclooxygenase-2 (COX-2) [97]. Furthermore, 76 decreased the secretion of pro-inflammatory cytokines, such as tumor necrosis factor- $\alpha$ (TNF- $\alpha$ ) and interleukin-1 $\beta$ (IL-1 $\beta)$ [97]. It also blocks the 
activation of nuclear factor-kappa B (NF-kB) in LPS-stimulated RAW264.7 macrophages by inhibiting the phosphorylation and degradation of inhibitor kappa B (IкB)- $\alpha$. Moreover, 76 decreased p38 mitogen-activated protein kinase (MAPK) phosphorylation (Figure 11) [97].

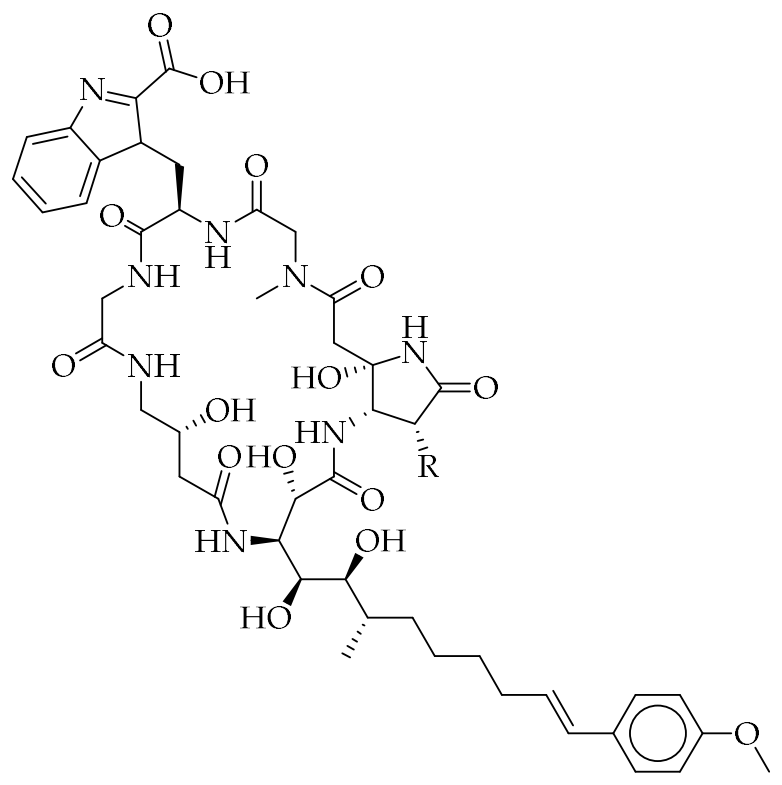

$\mathrm{R}=\mathrm{OH}$, Microsclerodermin $\mathrm{A}, 73$

$\mathrm{R}=\mathrm{H}$, Microsclerodermin B, 74

Cancer: Pancreas

Cancer Cell: AsPC-1

Biological Target: NF-kB

$\mathrm{IC}_{50}=1.2 \mu \mathrm{M}$

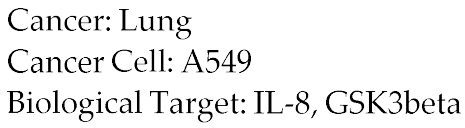

Figure 9. Chemical structures of Microsclerodermin A and B with a summary of their biological activity towards selected cancer targets.<smiles>COc1c2cc(OC)c3c(ccnc13)NC=C2</smiles>

Aaptamine, 75

$\begin{array}{ll}\text { Cancer: Cervical } & \text { Cancer: Breast } \\ \text { Cancer Cell: THP-1 } & \text { Cancer Cell: MDA-MB-231 } \\ \text { Biological Target: NF-kB } & \text { Biological Target: AP-1 } \\ \mathrm{IC}_{50}=0.7 \mu \mathrm{M} & \mathrm{IC}_{50}=2.1 \mu \mathrm{M}\end{array}$

Figure 10. Chemical structure of the benzo[de[1,6]]-naphthyridine alkaloid Aaptamine with a summary of its biological activity towards selected cancer targets.

Piperlongumine (PL), 77 is an amide alkaloid isolated from long pepper (Piper longum L.) [99]. Compound 77 induces the death of numerous cancer cell lines including pancreatic cancer, breast cancer, and leukemia $[100,101]$. The compound is one of several amide alkaloids from the genus Piper that have been found to possess anticancer activities among other biological activities $[99,101]$. Piperlongumine rapidly induces the death of human pancreatic cancer cells mainly through the induction of ferroptosis [101]. PL directly binds to and inhibits the antioxidant enzyme, glutathione S-transferase Pi 1, resulting in elevated 
intracellular ROS levels and subsequent apoptotic cell death in cancers. PL has been shown to cause cell cycle arrest $[99,101]$.<smiles>C=CC(C)(C)c1[nH]c2ccccc2c1/C=C1\NC(=O)C(C)NC1=O</smiles>

Neoechinulin A, 76

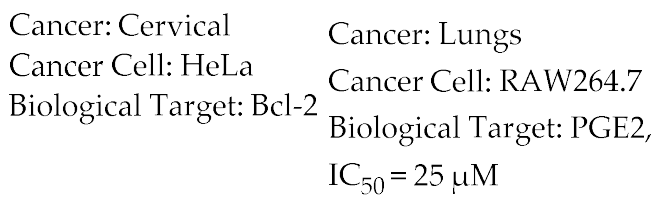<smiles>COc1cc(/C=C/C(=O)N2CCC=CC2=O)cc(OC)c1OC</smiles>

Piperlongumine, 77

Figure 11. Chemical structures of the amide alkaloids Neoechinulin A and Piperlongumine with a summary of their biological activity towards selected cancer targets.

Benzophenanthridine alkaloids are commonly found in Papaveraceae and Rutaceae and belong to the benzyl isoquinoline family. They have been extensively investigated for their medicinal properties and bioactive constituents [102]. Though they exhibit a variety of pharmacological functions, only those with multimodality anticancer activities are presented in the current review.

The benzophenanthridine alkaloids are generally isolated from natural sources as their quaternary ammonium salts. Sanguinarine, $\mathbf{7 8}$ has been isolated from the roots of Sanguinaria canadensis, Chelidonium majus, Argemone mexicana as well as the roots and leaves of Zanthoxylum(Fagara xanthoxyloides) zanthoxyloides, Z. bungeanum and Z. gilletii (Fagara macrophylla). The compound has diverse medicinal properties including anticancer properties. Although the underlying mechanism of action for Sanguinarine as an antitumor agent is yet to be fully elucidated, $\mathrm{Xu}$ et al. reported that $\mathbf{7 8}$ caused a concentrationdependent inhibition of growth in HeLa and SiHa human cervical cancer with $\mathrm{IC}_{50}$ values of 2.43 and $3.07 \mu \mathrm{M}$, respectively [103]. Cell cycle analysis revealed apoptosis induction was as a result of downregulation of Bcl-2 and NF- $\mathrm{KB}$ and an upregulation of Bax protein expression [103]. Sanguinarine is also reported to cause cell cycle obstruction and induce apoptosis of human prostate carcinoma cells via attenuation of cyclin dependent kinases (Figure 12) [104].

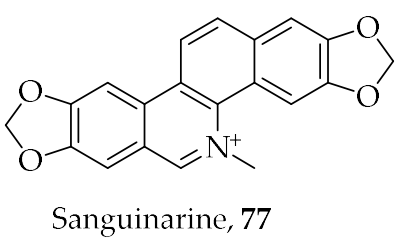
Cancer: Cervical
Cancer: Cervical
Cancer: Prostate
Cancer Cell: HeLa
Cancer Cell: SiHa
Cancer Cell: LNCaP
Biological Target: Bcl-2, NF-kB, Bax
Biological Target: Bcl-2, NF-kB, Bax
Biological Target: p21/WAF1, p27/KIP1, CDK 2, 4 and 6
$\mathrm{IC}_{50}=2.43 \mu \mathrm{M}$
$\mathrm{IC}_{50}=3.07 \mu \mathrm{M}$
$\mathrm{IC}_{50}=0.1 \mu \mathrm{M}$

Figure 12. Chemical structure of the quaternary ammonium salt alkaloid Sanguinarine with a summary of its biological activity towards selected cancer targets.

Chelerythrine 79, isolated from Chelidonium majus, Z. xanthoxyloides, Z. clavaherculis, and Z. rhoifolium among others, is a potent, selective, and cell-permeable protein kinase $C$ inhibitor [105]. Chelerythrine exhibits its antitumor properties by inhibiting the prolifera- 
tion of androgen-independent prostate cancer cells DU145 and PC-3 at concentrations of 5 and $10 \mu \mathrm{M}$ [106]. Western blot analysis revealed that $\mathbf{7 9}$ inhibited metastasis of prostate cancer cells by suppressing MMP-2, MMP-9, and uPA and also boosted the expression of endogenous inhibitors TIMP-1 and TIMP-2 as well as plasminogen activator inhibitors (PAI-1 and PAI-2) [106]. In vitro and in vivo studies have also disclosed the effects of $\mathbf{7 9}$ on the growth inhibition and apoptosis induction on HEK-293 and SW-839 renal cancer cells [107]. Chelerythrine, 79, also significantly inhibits the phosphorylation of extracellular signal-regulated kinase (ERK) and Akt accompanied by upregulation of p53, and downregulation of Bcl-2, caspase-3, and PARP (Figure 13) [107].<smiles>COc1ccc2c(c1)c(OC)c(OC)c[n+]2C</smiles>

Chelerythrine,79

Cancer: Prostate

Cancer Cell: DU145

Biological Target: MMP-2, MMP-9, uPA $\mathrm{IC}_{50}=5 \mu \mathrm{M}$
Cancer: Prostate

Cancer Cell: PC-3

Biological Target: MMP-2, MMP-9, uPA

$\mathrm{IC}_{50}=10 \mu \mathrm{M}$
Cancer: Renal

Cancer Cell: SW-839

Biological Target: ERK, Akt, p53, Bcl-2, caspase-3 and PARP

Figure 13. Chemical structure of Chelerythrine with a summary of its biological activity towards selected cancer targets.

Nitidine $\mathbf{8 0}$ is found mostly in the roots of Zanthoxylum nitidum (Fagara nitida), Z. gilletii (Fagara macrophylla), Z. tessmanii, and Z. chalybeum (Fagara chalybea). Nitidine was first reported from Z. nitidum in 1958 by Arthur et al. [108]. It was later reported from Z. gilletii (Fagara macrophylla) by Torto and Addae-Mensah in 1970, Wall et al. in 1971, and Fish and Waterman in 1972 [109-112]. Since then, it has been isolated from other Zanthoxylum species as well as Toddalia asiatica. It is usually isolated in the form of its chloride salt, and is noted mostly for its antimalarial and cardiovascular activities [113-115]. It has also been extensively investigated for its wide variety of bioactivity including its anti-tumor activity against various malignancies. Nitidine is a very strong inhibitor of topoisomerase I enzyme at $0.05-0.3 \mu \mathrm{M}$ with significant selectivity. However, its effect on topoisomerase II is only moderate [116,117]. DNA topoisomerases are enzymes that regulate the conformational changes in DNA topology by catalyzing the concerted cleavage and polymerization of DNA strands during cellular growth. Recent studies have identified them as putative targets for drug design against various forms of cancers. Nitidine also impedes breast cancer cell migration and invasion via inactivation of c-Src/FAK pathway as well as downregulation of MMP-2 and MMP-9 [118]. An in vivo study revealed the suppression of hepatocellular carcinoma cell proliferation by the inhibition of the JAK1/STAT3 signaling pathways. Associated with this is the increased levels of p21 and Bax as well as decreased levels of cyclinD1, CDK4 and Bcl-2 (Figure 14) [119].

The existence of nitidine and other benzophenanthridine alkaloids as quaternary salts is a major problem in their study for cancer chemotherapy and other diseases, especially in vivo studies, because of their poor absorption and hence bioavailability. In attempts to find possible drug delivery systems to enhance their cancer chemotherapeutic profiles, the pharmacodynamics of nitidine chloride on various types of nanoparticles have been studied and found to reduce toxicity and enhance anticancer effects [120].

Closely related to nitidine but less toxic are fagaronine, $\mathbf{8 1}$ and fagaridine, $\mathbf{8 2}$, which are major constituent alkaloids of Z. xanthoxyloides (Fagara xanthoxyloides). The two compounds have been extensively investigated for their mutagenic activities [121,122]. The anticancer activity of fagaronine was first reported by Messmer and his coworkers, who 
found it to effect complete cure in mice infected with the P-388 lymphocytic leukemia [123]. It was subsequently found to be very active against chronic myeloid leukemia (cell line K 562) as well as several other cancers of viral origin [124]. Fagaronine exhibits its antileukemic activity by inhibiting both Topoisomerase I and II at concentrations of 30 and $25 \mu \mathrm{M}$ [125]. Fagaridine, first reported from Z. xanthoxyloides by Torto et al., [126] inhibits topoisomerase I, effectively stabilizes topoisomerase I-DNA binary complex, and intercalates into DNA [127]. A synthetic isomer of fagaridine, N-109, is said to be more stable and possess greater activity than all the naturally occurring benzophenanthridine alkaloids (Figure 15) [109].<smiles>COc1cc2c[n+](C)c3c4cc5c(cc4ccc3c2cc1OC)OCO5</smiles>

Nitidine, 80

$\begin{array}{ll}\text { Cancer: Brease } & \text { Cancer: Brease } \\ \text { Cancer Cell: MDA-MB-231 } & \text { Cancer Cell: MDAMB-453 } \\ \text { Biological Target: c-Src/FAK } & \text { Biological Target: MMP-2, MMP-9 }\end{array}$

Figure 14. Chemical structure of Nitidine and a summary of its biological activity towards selected cancer targets.<smiles>COc1cc2c(ccc3c4ccc(OC)c(OC)c4c[n+](C)c23)cc1O</smiles>

Fagaronine, 81

Cancer: Leukemia

Cancer Cell: P388

Biological Target: Topoisomerase I

$\mathrm{IC}_{50}: 30 \mu \mathrm{M}$<smiles></smiles>

Fagaridine, 82

Cancer: Leukemia

Cancer Cell: P388

Biological Target: Topoisomerase I and II $\mathrm{IC}_{50}: 25 \mu \mathrm{M}$

Figure 15. Chemical structures of Fagaronine and Fagaridine with a summary of their biological activity towards selected cancer targets.

\subsection{S-Based Heterocycles}

In addition to the $\mathrm{N}$ - and $\mathrm{O}-$ based heterocycles, medicinal chemists have shifted their attention to S-based heterocycles because of their impressive biological attributes as anticancer, antidiabetic, antifungal and antihypertensive agents [128]. Currently, some FDA approved drugs have $S$-heterocycles as core moieties for the treatment of various diseases including cancer [128]. Below are some $S$-containing heterocycles with multitarget anticancer properties. 
Gliotoxin, 83 is a member of the epipolythiodioxopiperazine class of mycotoxins produced by Aspergillus fumigatus, Eurotium chevalieri, Gliocladium fimbriatum, and most Trichoderma, and Penicillium species as well as Neosartorya pseudofischeri [129]. It belongs to the 2,5-diketopiperazine class of natural products. Compound $\mathbf{8 3}$ has immunosuppressive properties such as the blockage of NF-KB activation [130] and modulates the immune response, affects circulating neutrophils, suppresses reactive oxygen species (ROS) production and inhibits phagocytosis of conidia [129]. It inhibits proliferation and induces apoptosis on colorectal and cervical cancer cells via caspase activation followed by up- and downregulations of Bax and Bcl-2, respectively (Figure 16) [131,132].<smiles>CN1C(=O)[C@]23CC4=CC=C[C@H](O)[C@@]4(SS2)N3C(=O)C1CO</smiles>

\section{Gliotoxin, 83}

Cancer: Cervical

Cancer Cell: SW1353, HeLa

Biological Target: Bcl-2, Bax, caspase-3, 8, and 9

$\mathrm{IC}_{50}=90 \mu \mathrm{M}$

Figure 16. Chemical structure of Gliotoxin and summary of its biological activity towards selected cancer targets.

During investigations aimed at repurposing Nonsteroidal Anti-Inflammatory Drugs (NSAIDs) COX-2 selective inhibitors against MCF-7 (human breast carcinoma), HT-29 (human colorectal adenocarcinoma), and A549 (human lung carcinoma) cancer cell lines, two diphenyl thiazole derivatives $\mathbf{8 4}$ and $\mathbf{8 5}$ were found to exhibit the highest potency with $\mathrm{IC}_{50}$ in the micromolar range [133]. Despite the weak activity of the two compounds against tubulin polymerization assays, they showed remarkable inhibition of EGFR and BRAF with $\mathrm{IC}_{50} \leq 40 \mu \mathrm{M}$ [133].

In the search for naturally occurring compounds with multitargeting potential against breast cancer cell lines, the alkaloid ellipticine $\mathbf{8 6}$ was found to exhibit topoisomerase I and tubulin polymerase inhibition [134]. However, it was found to have numerous deleterious side effects. The continued search for other heterocyclic compounds with activities like that of ellipticine but with reduced deleterious side effects led to the investigation of several heterocyclic compounds containing both nitrogen and sulfur. Six benzothienoquinazolinone derivatives were synthesized via isosteric iteration. Two of the six, compounds 87 and 88, were the most active compounds inhibiting topoisomerase 1 and tubulin polymerization [135]. The two compounds also exhibited aggressive activity against MDA-MB-231 cell lines with $\mathrm{IC}_{50}$ of $3.88 \mu \mathrm{M}$ and $4.69 \mu \mathrm{M}$, respectively and moderate inhibition activity against MCF-7 cells at 40.70 and $41.99 \mu \mathrm{M}$ (Figure 17) [135].

The ability of a bioactive compound to quench activities that lead to abnormal cell growth has been applied in the treatment of inflammatory-related diseases. Five highly reactive naphthoquinones (89-93) investigated by Aly et al. showed promising anti-tumor activity via cell cycle arrest in the pre-G1 and G2/M phases and downregulation of cyclindependent kinases (CDK) [136]. Three of them, 91-93 were found to be strong inhibitors of cyclic dependent kinases with 91 being the most potent. Compound 91 attenuated eight isoforms of CDK and phosphor-tyr15 and also induced apoptosis and cell cycle arrest by downregulating pre-G1 and G2/M phases, respectively [136].

In similar studies involving heterocyclic compounds containing nitrogen and sulphur, ten [1,2,4]-triazine derivatives 94-103 (Table 1) were investigated for their anti-cancer properties. The compounds were synthesized from phenylisothiocyanate and ethanol- 
containing triethylamine via a multi-component reaction. The synthesized compounds were found to be potent at nanomolar and sub-micro concentrations towards six tyrosine kinase receptors (c-Met, c-Kit, Flt-3, VEGFR-2, EGFR, and PDGFR). Compound 95 bound strongly to all the receptors except EGFR [137]. Estimation of the series efficacy against PIM-1 activity showed compounds 95-99 and 101-103 as the most potent [137].

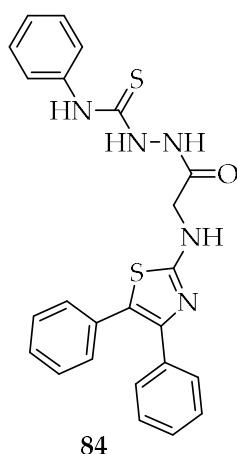

Cancer: Breast

Cancer Cell: MCF-7

Cancer: Colorectal

Cancer Cell: HCT-116 Biological Target: BRAF

Biological Target: EGFR $\mathrm{IC} 50=37.28 \mu \mathrm{M}$ $\mathrm{IC}_{50}=21.96 \mu \mathrm{M}$

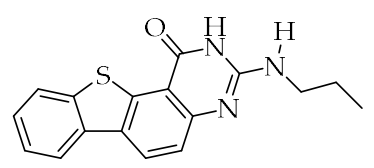

87

Cancer: Breast

Cancer: Breast

Cancer Cell: MDA-MB-231

Biological Target: Tubulin

$\mathrm{IC}_{50}=3.88 \mu \mathrm{M}$
Cancer Cell: MCF-7

Biological Target: Topo 1

$\mathrm{IC}_{50}=40.70 \mu \mathrm{M}$

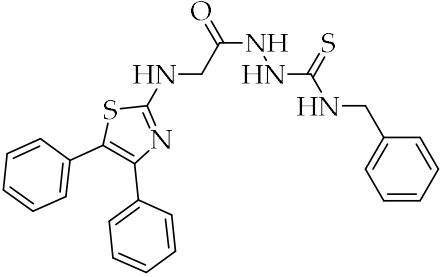

85

Cancer: Hepatocellular Cancer: Colorectal Cancer Cell: HEPG-2 Cancer Cell: HCT-116 Biological Target: EGFR Biological Target: BRAF $\mathrm{IC}_{50}=22.31 \mu \mathrm{M} \quad \mathrm{IC}_{50}=25.94 \mu \mathrm{M}$

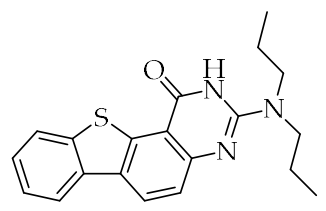

88

Cancer: Breast Cancer: Breast

Cancer Cell: MDA-MB-231 Cancer Cell: MDA-MB-231

Biological Target: Tubulin Biological Target: Tubulin

$\mathrm{IC}_{50}=4.69 \mu \mathrm{M}$

$\mathrm{IC}_{50}=41.99 \mu \mathrm{M}$

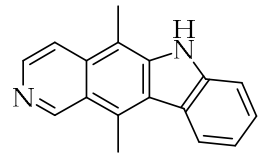

Ellipticine, 86

Cancer: Endometrial Cancer Cell: RL95-2

Biological Target: Topoisomerase $\mathrm{IC}_{50}=10 \mu \mathrm{M}$

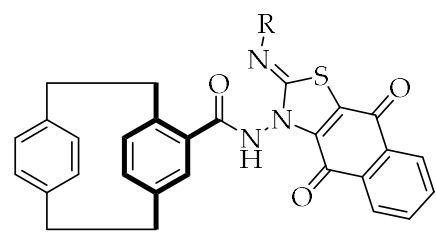

$$
\begin{aligned}
& \mathrm{R}=\text { Ph, } 89 \\
& \mathrm{R}=\text { Benzyl }, 90 \\
& \mathrm{R}=\text { Allyl }, 91 \\
& \mathrm{R}=\text { Ethyl, } 92 \\
& \mathrm{R}=\text { Cyclopropyl, } 93
\end{aligned}
$$

\begin{tabular}{|c|c|c|c|c|c|c|c|c|}
\hline Compound No. & Cpd & c-Met & c-Kit & Flt-3 & VEGFR-2 & EGFR & PDGFR & Pim-1 \\
\hline & 94 & 3.42 & 0.32 & 0.24 & 0.63 & 0.42 & 0.57 & $>10,000$ \\
\hline 94 & & & & & & & & \\
\hline
\end{tabular}

Figure 17. Structures of the diphenyl thiazoles 84 and 85 , ellipticine 86 , benzothienoquinazolinones 87 and 88 with a summary of their biological activity towards selected cancer targets.

Table 1. Inhibitory activity of protein kinase enzymes ( $\left.\mathrm{IC}_{50} / \mathrm{nM}\right)$ by synthesized 1,2,4-triazine derivatives [137]. 
Table 1. Cont.

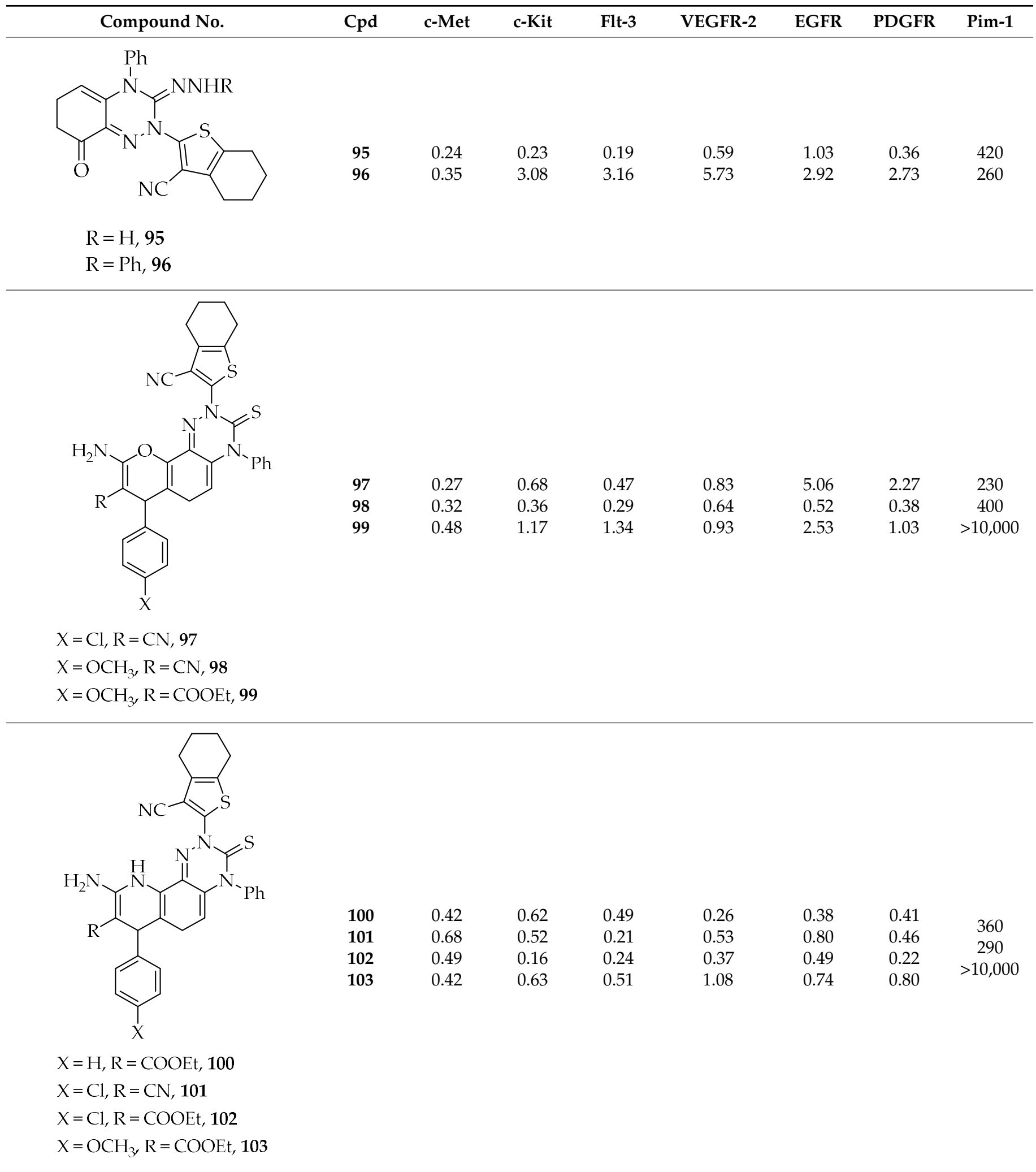

\subsection{O-Heterocyclic}

Several synthetic and naturally occurring oxygen heterocycles belonging to various compound classes such as terpenoids, coumarins, flavonoids and acetogenins have been 
investigated for their anti-cancer activities. Three new naturally occurring acetogenins from the family Annonaceae, isolated from the seeds of Annona squamosa (compounds 104-106, (Figure 18) have been reported by Pardhasaradhi et al. to possess radical-generating properties against MCF-7 and K-562 [138]. Studies by other researchers revealed that the compounds also induce apoptosis accompanied by organelle deformations like DNA fragmentation and phosphatidyl serine externalization [139].

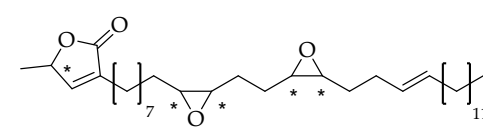

104

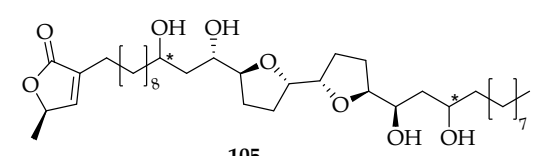

105

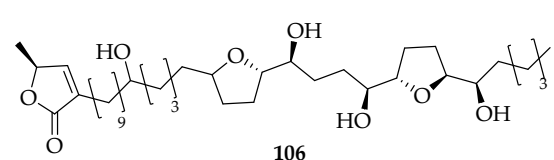

106<smiles>C/C=C(/C)C(=O)OCC1C[C@@H](C)OC2(O)CCC[C@]1(C)C=C1OC(=O)C(COC(C)=O)=C12</smiles>

107

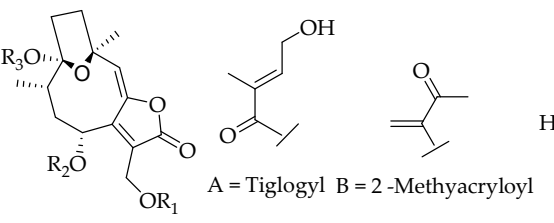

$\mathrm{R}_{1}=\mathrm{A}, \mathrm{R}_{2}=\mathrm{H}, \mathrm{R}_{3}=\mathrm{H}, 108$

$R_{1}=$ Acetyl, $R_{2}=A, R_{3}=H, 109$

$\mathrm{R}_{1}=$ Acetyl, $\mathrm{R}_{2}=\mathrm{B}, \mathrm{R}_{3}=\mathrm{H}, \mathbf{1 1 0}$

$\mathrm{R}_{1}=\mathrm{Acetyl}, \mathrm{R}_{2}=\mathrm{A}, \mathrm{R}_{3}=\mathrm{CH}_{3}, 111$

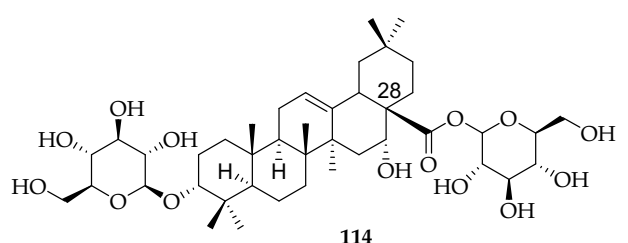

114<smiles>O=c1cc(-c2ccc(O)c(O)c2)oc2cc(OC3OC(CO)[C@@H](O)C(O)[C@H]3O)cc(O)c12</smiles>

114

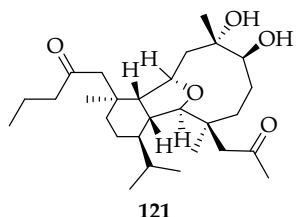

118<smiles>COc1cc(O)c2c(c1)oc(=O)c1c3cc(O)c(O)cc3oc21</smiles>

112

113<smiles>O=c1cc(-c2ccc(O)c(O)c2)oc2cc(O)cc(O)c12</smiles>

116

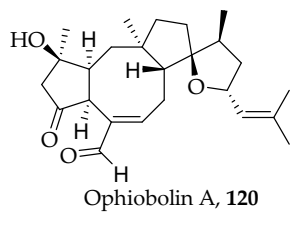

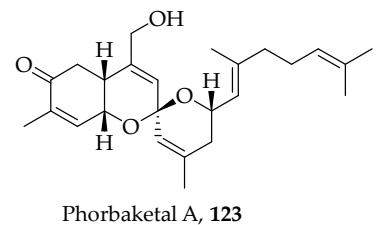

Figure 18. Structures of acetogenins 104-106, sesquiterpene lactones, 107-111 and compounds isolated from Eclipta prostrata 113-117.

In the area of cancer chemotherapy, transcriptional factors in modulation target have received little attention. In this regard, Youn et al. investigated the regulation of atypical oncogenes, particularly NF-KB and STAT3 transcriptional factors. They found that the sesquiterpene lactones, 107-111 (Figure 18) isolated from Vernonia cinerea exhibited promising TNF- $\alpha$-induced NF- $\mathrm{B}$ and NO activity $[140,141]$. While compound 109 was the most potent with $\mathrm{IC}_{50}$ value of $0.6 \mu \mathrm{M}$ against TNF- $\alpha$-induced $\mathrm{NF}-\kappa \mathrm{B}$ and $2.0 \mu \mathrm{M}$ against $\mathrm{NO}$ targets, the other compounds showed moderate inhibition with $\mathrm{IC}_{50}$ values between 10.2 and 13.6 $\mu \mathrm{M}$ [141]. Furthermore, all the sesquiterpene lactone isolates exhibited significant STAT3 aberrations [140]. Similarly, compound 112 was screened against human umbilical vein endothelial cells (HUVECs). It significantly suppressed the vascular endothelial growth factor and downstream hypoxia-inducible factor- $1 \alpha(\mathrm{HIF}-1 \alpha)$, which are used by tumor cells to survive and grow in microenvironments, at a very low concentration of $0.026 \mu \mathrm{M}$ [142]. 
Ethnobotanical and phytochemical studies of Eclipta prostrata led to the isolation of four compounds 113-117 (Figure 18) [143]. Mechanistic studies revealed that 101 activated caspase dependent apoptosis via tight inhibition of 5-LOX at $2.5 \mu \mathrm{M}[143,144]$. Compound 114, which differs from 115 by an additional glycone at the C-28 position, induces apoptosis in a caspase-independent manner via blocking of significant pathways like mammalian target of rapamycin (mTOR) and mitogen-activated protein kinase (MAPK) in human ovarian cancer cells at $94.87 \mu \mathrm{M}$ [145]. The anticancer property of luteolin, 116, a tetrahydroflavone, was associated with induction of apoptosis via redox regulation, DNA damage, and protein kinases in inhibiting proliferation of cancer cells [146]. Compound 116 also suppresses metastasis and angiogenesis through downregulation of survival pathways, such as PI3K/Akt, NF-kB, and MAPK [146]. A 7-O-glucoside derivative of 116 was found to decrease the proliferation of HepG2 cells along with changes in nuclear structure and DNA fragmentation in a dose dependent manner [147]. The effect of 116 on growth inhibition factors was attributed to the G2/M phase arrest and ROS generation with high phosphorylation of c-Jun N-terminal kinases (JNK) [147]. Another multitarget anticancer compound with high selectivity for cell cycle regulatory proteins is the isoflavone 118 [148]. Collectively, compound $\mathbf{1 1 8}$ disrupts activities of cyclin dependent kinases and other cell cycle regulatory proteins resulting in cell cycle arrest with $\mathrm{IC}_{50}$ values within the micromolar range [148]. Similarly, compound 119, a fungal metabolite with potent antitumor and anti-inflammatory effects with efficacy at $10 \mu \mathrm{M}$ against prostate cancer cell lines was observed to inhibit both STAT3 and NF- $\mathrm{KB}$ transcription and destabilize microtubules and G2/M cell cycle arrest $[149,150]$. Though the exact mechanism of action of compound 120 is not known, it is reported to have effects on proliferation and migration of human cancer cells. Bury et al. found that $1 \mu \mathrm{M}$ of compound 120 induced changes in the organization of the actin filaments in the cytoskeleton and disruption of $\mathrm{Ca}^{2+}$-activated $\mathrm{K}^{+}$channel activity [151].

The marine environment has been a productive source of potential anticancer agents. One of the most recognized genera as a rich source of eunicellin-based diterpenoids, such as the pachycladins, is Cladiella sp. [152]. One such isolate, compound 121 inhibited breast cancer cell growth via down-regulation of the NF- $\mathrm{BB}$ and up-regulation of the Heme oxygenase-1 (HO-1) pathways in a dose-responsive manner, with an $\mathrm{IC}_{50}$ value of $1.6 \mu \mathrm{M}$ [152]. Pharmacophoric group analysis indicated that the acetate and butyrate moieties at C-3 and C-11 were responsible for optimal antiproliferative activity [152].

Phorbaketal A, a tricyclic sesterterpenoid phorbaketal, 122 isolated from the marine sponge Phorbas sp by Yun-Ji Seo was also evaluated for its anticancer potential [153]. It showed significant inhibition of Lipopolysaccharide (LPS)-induced production of nitric oxide (NO) via dampening of inducible nitric oxide synthase (iNOS). It further showed expression at the transcriptional level along with NF-KB deactivation in RAW 264.7 cell [153]. Compound 122 also induced ROS generation through HO-1 expression at $10 \mu \mathrm{M}[153,154]$.

Glycyrrhiza uralensis Fisch (Glycyrrhiza glabra Linn), also known as licorice or Chinese liquorice is one of the most important and oldest phytomedicines in China [155-157]. It has been used for ages for the treatment of several diseases, especially those of inflammatory origins. It is also approved as a food additive and various medicinal preparations as a sweetener. Recent attention on the crude drug as well as its chemical components has been on its anticancer properties. It acts by modulating pro-inflammatory mediators and activating the immune system [158,159]. In vitro studies on Glycyrrhizic acid (Glycyrrhizin), 123, a triterpenoid glycoside from the roots of the plant, showed that the compound downregulates pro-inflammatory modulators NF- $\kappa \mathrm{B}$ and thromboxane synthase causing apoptosis on lung adenocarcinoma, hepatoma, leukemia, stomach, and prostate cancer cell lines (Figure 19) [160-162]. Its effects on tumor growth and endometrial cancer progression are through suppression of COX-2, TNF- $\alpha$, IL-1, ornithine decarboxylase (ODC) activity, DNA synthesis, and TxA2 [162-164]. The compound also downregulates reactive oxygen species (ROS)-induced damage. 


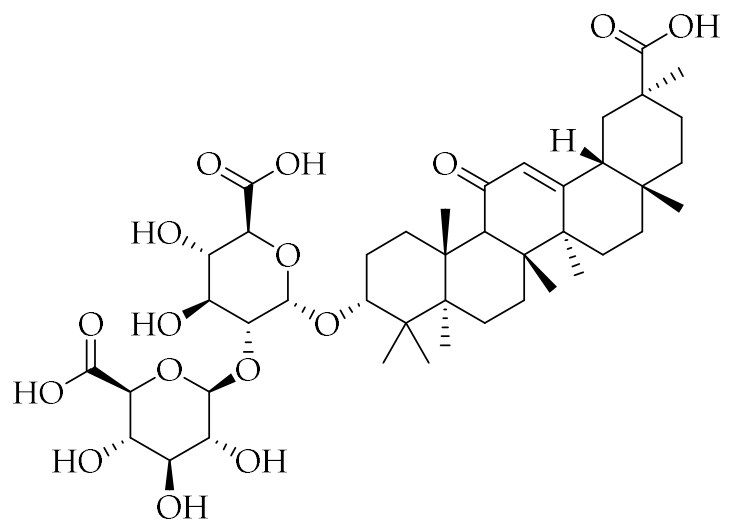

Glycyrrhizic acid, 123

$\begin{array}{lll}\text { Cancer: Prostate } & \text { Cancer: Leukemia } & \text { Cancer: Lungs } \\ \text { Cancer Cell: LNCap } & \text { Cancer Cell: WEHI-3 } & \text { Cancer Cell: A549 } \\ \text { Biological Target: CCK-8 } & \text { Biological Target: DNA } & \text { Biological Target:TxAS,VGEF } \\ \mathrm{IC}_{50}: 0.0085 \mu \mathrm{M} & \mathrm{IC}_{50}: 0.0125 \mu \mathrm{M} & \mathrm{IC}_{50}: 0.001 \mu \mathrm{M}\end{array}$

Figure 19. Structure of the triterpenoid glycoside Glycyrrhizic acid with a summary of its biological activity towards selected cancer targets.

A dihydroxyflovanone compound, Liquiritigenin, 124, isolated from the roots of the same plant [165] is an estrogenic that acts as a selective agonist of the ER $\beta$ subtype of the estrogen receptor (ER) (Figure 20) [166]. It is also reported to act as an estrogen receptor alpha $(E R \alpha)$ partial agonist [167]. Liquiritigenin, has been screened against hepatic cancer cell SMMC-7721 and HeLa cells and found to activate apoptosis via MMP-2 activity and dephosphorylation of Akt [156,168].<smiles>O=C1C[C@H](c2ccc(O)cc2)Oc2cc(O)ccc21</smiles>

Liquiritigenin, 124
Cancer: Cervical
Cancer: Cervical
Cancer Cell: HeLa
Cancer Cell: HeLa
Biological Target: Bax, Bcl-2
Biological Target: Succinate dehydrogenase
$\mathrm{IC}_{50}=0.000247 \mu \mathrm{M}$
$\mathrm{IC}_{50}=0.0001 \mu \mathrm{M}$

Figure 20. Structure of the dihydroxyflovanone Liquiritigenin with a summary of its biological activity towards selected cancer targets.

Isoangustone A, $\mathbf{1 2 5}$ is a 6-prenylated isoflavanone lipid molecule isolated from the root of Glycyrrhiza (Figure 21). Compound 125 induces apoptosis in SW480 human colorectal adenocarcinoma cells by disrupting mitochondrial function [169]. 
<smiles>CC(C)=CCc1cc(-c2coc3cc(O)c(CC=C(C)C)c(O)c3c2=O)cc(O)c1O</smiles>

Isoangustone A, 125

$\begin{array}{lll}\text { Cancer: Colorectal } & \text { Cancer: Prostate } & \text { Cancer: Melanoma } \\ \text { Cancer Cell: SW480 } & \text { Cancer Cell: DU 145 } & \text { Cancer Cell: SK MEL 2 } \\ \text { Biological Target: mTOR } & \text { Biological Target: mTOR, PI3 K } & \text { Biological Target: Akt, JNK } \\ \mathrm{IC}_{50}=0.0002 \mu \mathrm{M} & & \end{array}$

Figure 21. Structure of the 6-prenylated isoflavanone lipid Isoangustone A with a summary of its biological activity towards selected cancer targets.

The antiproliferation mechanism of $\mathbf{1 2 5}$ has been studied in SW480 human colorectal adenocarcinoma cells [170], prostate cancer cells (PC3, LNCaP, DU 145, and 4 T1) [171,172] and melanoma cells (SK-MEL-2, SK-MEL-5, SK-MEL-28, WM-266-4 cell lines) [171]. Cell cycle arrest and apoptosis via the cessation of cyclin A, cyclin D, cyclin E, CDK2, and CDK4 protein expression and the downregulation of mTOR, PI3 K, Akt, and JNK were the major disrupted pathways identified [171].

Another component of the root of licorice is the isoflavonoid glabridin, $\mathbf{1 2 6}$ from the root of Glycyrrhiza glabra. Compound $\mathbf{1 2 6}$ inhibits cyclooxygenase activity and has an anti-inflammatory and an antiplatelet effect (Figure 22) [173].<smiles>CC1(C)C=Cc2c(ccc3c2OCC(c2ccc(O)cc2O)C3)O1</smiles>

Glabridin, 126

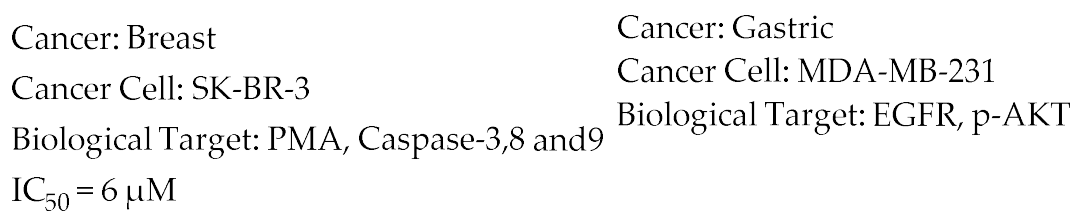

Figure 22. Structure of an isoflavonoid Glabridin with a summary of its biological activity towards selected cancer targets.

Studies in modulating metastatic cascade have demonstrated the efficacy of compound $\mathbf{1 2 6}$ via interference of focal adhesion kinase (FAK), proto-oncogene-protein kinase (Src), protein kinase $\mathrm{B}$ (Akt), myosin, myosin light chain phosphorylation, and ras homolog family member A (RhoA) with decreased expression and activities of MMP-9, phosphorylation of ERK1/2 and JNK1/2 [174].

Isoliquiritin, $\mathbf{1 2 7}$ is a flavonoid glycoside from licorice possessing a broad spectrum of pharmacological activities including antioxidant, anti-inflammatory, and anti-depression activities. Compound $\mathbf{1 2 7}$ and its biosynthesized derivative isoliquiritin apioside, 128, prevent angiogenesis and tube formation through the inhibition and suppression of proangiogenic factors including MMP-9, placental growth factor, and vascular endothelial 
growth factor under normoxia as well as hypoxia conditions by impairing the hypoxiainducible factor-1 $\alpha$ pathway in HT1080 cells (Figure 23) [175,176].<smiles>O=C(/C=C/c1ccc(O[C@@H]2O[C@H](CO)[C@@H](O)[C@H](O)[C@H]2O)cc1)c1ccc(O)cc1O</smiles>

Isoliquiritin, $\mathbf{1 2 7}$<smiles>O=C(/C=C/c1ccc(O[C@@H]2O[C@H](CO)[C@@H](O)[C@H](O)[C@H]2O[C@@H]2OC[C@](O)(CO)[C@H]2O)cc1)c1ccc(O)cc1O</smiles>

Isoliquiritin apioside, $\mathbf{1 2 8}$

Cancer: Fibrosarcoma

Cancer Cell: HT1080

Biological Target: VEGF, PMA, PGF, MMP-9

$\mathrm{IC}_{50}=100 \mu \mathrm{M}$

Figure 23. Structures of the flavonoid glycoside Isoliquiritin and its biosynthesized derivative isoliquiritin apioside with a summary of their biological activity towards selected cancer targets.

An isolate from Glycyrrhiza uralensis, Licoricidin, $\mathbf{1 2 9}$ is another prenylated isoflavonoid that has been found to inhibit SW480 cells $\left(\mathrm{IC}_{50} 7.2 \mu \mathrm{M}\right)$ by inducing cycle arrest, apoptosis, and autophagy. It exhibits a range of biological activities including antibacterial, anti-aging, and anticancer activities. It is a potential chemopreventive or chemotherapeutic agent against colorectal cancer (Figure 24) [177]. Compound 129 exhibits its anticarcinogenic effects by inhibiting lung metastasis via suppression of tumor angiogenesis and lymphangiogenesis as well as changing in the local microenvironment of the tumor tissues [178]. It also enhances enhanced gemcitabine-induced cytotoxicity in Osteosarcoma (OS) cells through inactivation of the Akt and NF-KB pathways [179]. The compound also blocks UVA-induced photoaging via ROS scavenging and limits the activity of MMP-1 [180].<smiles>COc1c(O)cc2c(c1CC=C(C)C)C[C@@H](c1ccc(O)c(CC=C(C)C)c1O)CO2</smiles>

Licoricidin, 129

Cancer: Colorectal

Cancer Cell: SW480

Biological Target: CDK1, Akt/mTOR

$\mathrm{IC}_{50}=7.2 \mu \mathrm{M}$
Cancer: Prostate

Cancer Cell: Du-145

Biological Target: MMP-9

$\mathrm{IC}_{50}=100 \mu \mathrm{M}$

Figure 24. Structure of the prenylated isoflavonoid Licoricidin with a summary of its biological activity towards selected cancer targets.

Compound 129 has been found to inhibit the migration and adhesion of DU 145 cells in a concentration-dependent manner through the reduction of MMP-9, Urokinase-type Plasminogen Activator (uPA), VEGF, integrin- $\alpha 2$, Intercellular Adhesion Molecule (ICAM), 
and Vascular Cell Adhesion Molecule (VCAM) secretion [178]. Incubation of glycyrol, 130 against human Jurkat cells, arrests the $S$ phase of the cell cycle by activation of the Fas cell surface death receptor (Fas), caspase-8, and caspase-9 proteins but through the JNK pathway in HCT 116 cells [181].

Coumarins are another class of oxygen heterocyclic compounds with diverse bioactivities including anti-cancer activities. Licocoumarone, $\mathbf{1 3 1}$ is one of such compounds isolated from Glycyrrhiza uralensis. It acts as an apoptosis-inducing agent [182]. The potency of 131 against cancer cell lines, chromatin condensation and nucleus fragmentation has been investigated and found to induce apoptosis (Figure 25) [183,184].<smiles>COc1c(CC=C(C)C)c(O)cc2oc(=O)c3c4ccc(O)cc4oc3c12</smiles>

Glycyrol, 130<smiles>COc1c(CC=C(C)C)c(O)cc2oc(-c3ccc(O)cc3O)cc12</smiles>

Licocoumarone, 131

Cancer: Pancreas

Cancer Cell: BxPC-3

Biological Target: DYRK1A

$\mathrm{IC}_{50}=5.89 \mu \mathrm{M}$

Figure 25. Structures of Glycyrol and Licocoumarone with a summary of their biological activity towards selected cancer targets.

Recently, the extensive ethnomedicinal use of plants containing lignans has attracted the interest of many natural product and medicinal chemists. Podophyllotoxin (PTOX), 132, is a lignan produced by various species of Podophyllum genus such as Podophyllum emodi Wall. (syn. P. hexandrum) and Podophyllum peltatum L. (Berberidaceae) [185]. Other genera such as Jeffersonia, Diphylleia, and Dysosma (Family Berberidaceae), Catharanthus (Apocynaceae), Polygala (Polygalaceae), Anthriscus (Apiaceae), Linun (Linaceae), Hyptis (Verbenaceae), Teucrium, Nepeta and Thymus (Labiaceae), Thuja, Juniperus, Callitris and Thujopsis (Cupressaceae), Cassia (Fabaceae), Haplophyllum (Rutaceae), Commiphora (Burseraceae), and Hernandia (Hernandiaceae) have also been reported to produce podophyllotoxin (PTOX) and its derivatives as well as other lignans [185]. Podophyllotoxin, 132 and deoxypodophyllotoxin, 133, both cyclolignans from the Anthriscus and Juniperus genera have shown excellent therapeutic effect on cancer cells with tubulin, and DNA topoisomerase II as potential targets (Figure 26) [186,187].

Iridoid glycosides are another class of naturally occurring oxygen heterocyclics reported to have a variety of biological activities including antidiabetic, antibiotic, antiinflammatory, and antioxidant activities. They have been found in several plant species including Canthium subcordatum, Alchornea cordifolia, Eucommia ulmoides, and Gardenia species [188-191].

Ginipin 134, Geniposide 135, and Geniposidic acid 136 are iridoid glycosides found in several plants including Eucommia ulmoides, Gardenia jasminoides, and Gardenia fructus (Figure 27). They possess a range of biological activities including anticancer properties. Their mechanisms of action towards cancer include generation of reactive oxygen species, mitochondria dysfunction and cell-cycle regulation as the leading cause of cell death [192,193]. Particularly, compound 134 causes increased levels of Bax in response to p38 MAPK signaling, leading to the initiation of the mitochondrial death cascade [194] whereas compound 135 inhibits hydroperoxide and myeloperoxidase formation caused by 12-O-tetradecanaoylphorbol-13-acetate (TPA) displacement $[195,196]$. 
<smiles></smiles>

Podophyllotoxin, 132

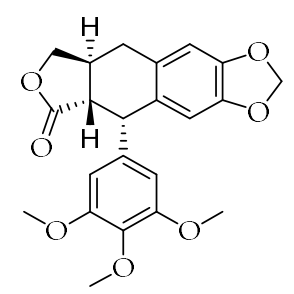

Deoxypodophyllotoxin, $\mathbf{1 3 3}$

$\begin{array}{ll}\text { Cancer: Cervical } & \text { Cancer: Lungs } \\ \text { Cancer Cell: HeLA } & \text { Cancer Cell: H460 } \\ \text { Biological Target: MTT } & \text { Biological Target: DNA Top II } \\ \mathrm{IC}_{50}=2.27 \mu \mathrm{M} & \mathrm{IC}_{50}=5.94 \mu \mathrm{M}\end{array}$

Figure 26. Structure of the cyclolignans Podophyllotoxin and Deoxpodophyllotoxin with a summary of their biological activity towards selected cancer targets.<smiles>COC(=O)C1=CO[C@H](O)[C@H]2C(CO)=CC[C@H]12</smiles>

Genipin, 134

Cancer: Gastric Cancer Cell: AGS

Biological Target: Egr1/p21 $\mathrm{IC}_{50}=100 \mu \mathrm{M}$<smiles>COC(=O)C1=CO[C@@H](O[C@@H]2O[C@H](CO)[C@@H](O)[C@H](O)[C@H]2O)[C@H]2C(CO)=CC[C@H]12</smiles>

Geniposide, 135

Cancer: Liver Cancer Cëll: Hep3B

Biological Target: FAO

$\mathrm{IC}_{50}=200 \mu \mathrm{M}$<smiles>O=C(O)C1=CO[C@@H](O[C@@H]2O[C@H](CO)[C@@H](O)[C@H](O)[C@H]2O)C2C(CO)=CCC12</smiles>

Geniposidic acid, 136

Cancer: Lungs

Cancer Cell: H1299

Biological Target: myeloperoxidase $\mathrm{IC}_{50}=351.5 \mu \mathrm{M}$

Figure 27. Structure of the iridoid glycosides Genipin, Geniposide and Geniposidic acid with a summary of their biological activity towards selected cancer targets.

Thapsigargin, $\mathbf{1 3 7}$ is a sesquiterpene lactone isolated from the umbelliferous plant, Thapsia gargantea [197]. It has antitumor activity in the low micromolar range when tested in human cancer cell lines. Cytotoxicity effects are generally attributed to imbalance of calcium homeostasis through interference with sarcoplasmic/endoplasmic reticulum $\mathrm{Ca}^{2+}$ ATPase [197]. The compound stimulates MAP kinase signaling via Src and Raf- 1 . The tumorigenic properties demonstrated by $\mathbf{1 3 7}$ are partially attributed to activation of the Src-MAP kinase pathway [197]. Thapsigargin also induces perturbations in calcium homeostasis and an increase in nitric oxide production eliciting apoptosis and cell death (Figure 28) [198-200].

Farnesiferol C (FC), $\mathbf{1 3 8}$ is a sesquiterpene coumarin isolated from Ferula species (Apiaceae) [201]. It possesses cytotoxic, apoptotic, MDR reversal, antitumor, and antimutagenic properties among other bioactivities (Figure 29). Compound 138 induces cell cycle arrest and apoptosis mediated by oxidative stress in the MCF-7 cell line [202]. It is also reported to deactivate vascular endothelial growth factor (VEGF)-induced cell proliferation, migration, invasion, and tube formation that is the cause of cancer metastasis [202]. 


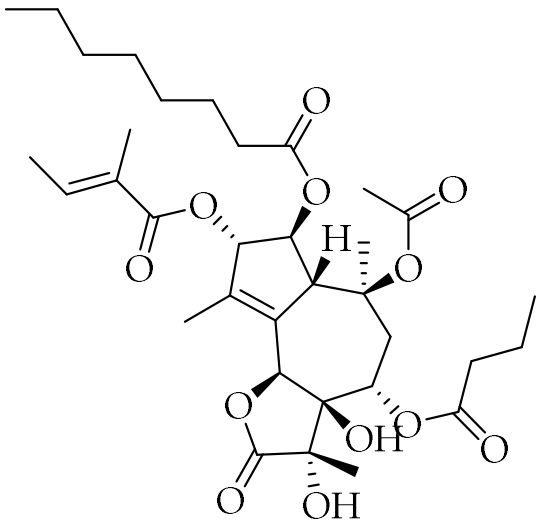

Thapsigargin, 137

Cancer: Lung

Cancer Cell: A549

Biological Target: SERCA

$\mathrm{IC}_{50}=0.1 \mu \mathrm{M}$

Figure 28. Structure of the sesquiterpene lactone Thapsigargin with a summary of its biological activity towards selected cancer targets.<smiles>C/C(=C\COc1ccc2ccc(=O)oc2c1)CCC1C(C)(C)C2CC[C@]1(C)O2</smiles>

Farnesiferol C, 138

Cancer: Breast

Cancer Cell: MCF-7
Cancer: Ovary

Cancer Cell: A549
Cancer: Prostate

Cancer Cell: H460

Biological Targets: SOD, MDA Biological Targets: CAT, Caspase-9 Biological Targets: Bcl-2, ROS $\mathrm{IC}_{50}=14 \mu \mathrm{M}$

Figure 29. Structure a sesquiterpene coumarin Farnesiferol $C$ with the summary of its biological activity towards selected cancer targets.

Rhamnose is a naturally occurring deoxy sugar that is derived from plants such as Buckthorn, poison sumac, birch trees, and bacteria [203-205]. Among the many applications, rhamnose is used in the treatment of skin cancer. L-Rhamnose, 139 and L-fucose, 140 activate apoptosis via the mitochondria pathways particular on the Bcl-2 family proteins [204,205]. In addition, rhamnose $\alpha$-hederin, $\mathbf{1 4 1}$ is reported to inhibit the 3.5 million PI3K/AKT pathway and activate ERK pathway on breast cancer cells (Figure 30) [206].

Ophiopogonin B, 142 occurs in the herbs Radix O. japonicus, Ophiopogonis radix (ophiopogonis root), and O japonicus [207]. It is widely used in Chinese traditional medicine. It has a range of anticancer properties against various types of cancer including lung cancer, cervical cancer and gastric cancer [208]. Investigation of changes in intracellular activity of incubated cells with compound $\mathbf{1 4 2}$ using the Western blot method resulted in increased protein expression levels of caspase 3 and B-cell lymphoma 2 (Bcl-2)-associated $X$ protein [208]. Compound 142 also inhibited the proliferation of NPC cells by inducing apoptosis and disturbing the mitochondrial integrity [209]. In addition, compound 142 promotes the expression of mammalian STE20-like kinase 1, large tumor suppressor 1, and 
phosphorylated-associated protein (YAP), suppresses the expression of YAP and transcriptionally enhances associate domains in NPC cells (Figure 31) [209].<smiles>C[C@@H]1OC(O)[C@H](O)[C@H](O)[C@H]1O</smiles>

L-Rhamnose, 139

Cancer: Breast

Cancer Cell: BT474

Biological Targets: Caspase- 3 and 9<smiles>C[C@@H]1OC(O)[C@H](O)[C@H](O)[C@H]1O</smiles>

L-Fucose, 140

Cancer: Breast

Cancer Cell: MDA-MB-231

Biological Targets: ERK

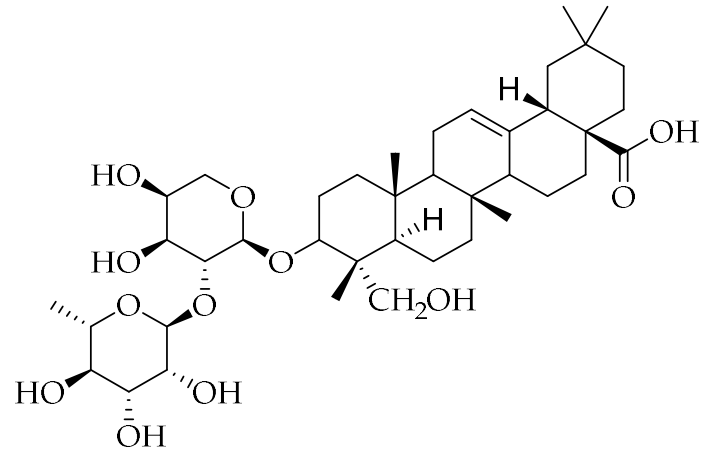

Rhamnose alpha-hederin, 141

Cancer: Breast

Cancer Cell: MCF-7

Biological Target: P13K/AKT

Figure 30. Structures of deoxy sugars L-Rhamnose, L-Fucose, and rhamnose $\beta$-hederin with a summary of their biological activity towards selected cancer targets.

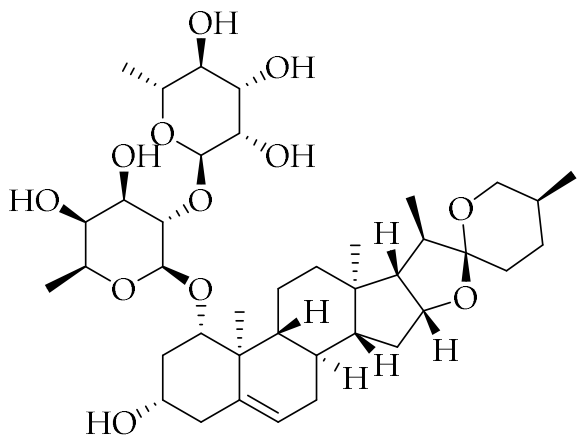

Ophiopogonin B, 142

Cancer: Gastric

Cancer Cell: SGC-7901

Biological Targets: Caspase-3, Bcl-2, JNK, ERK

$\mathrm{IC}_{50}=20 \mu \mathrm{M}$

Figure 31. Structure of the saponin Ophiopogonin B with a summary of its biological activity towards selected cancer targets.

The anti-cancer properties of some oxygen heterocyclics of marine origin and their mechanism of action have also received attention in recent times. The molecular mechanisms by which some of these marine natural products activate apoptosis mainly include dysregulation of the mitochondrial pathway, the activation of caspases, and/or increase of death signals through transmembrane death receptors [210]. Mitogenic roles of VEGF and modulation of the NF- $\mathrm{kB}$ pathway have been demonstrated to be the major underlying mechanism of action [211-213].

Fucoxanthin, 143 is a naturally occurring brown- or orange-colored pigment that belongs to the class of non-provitamin A carotenoids present in the chloroplasts of brown seaweeds [214]. Anti-proliferative and cancer preventing properties of compound 143 and its derivative fucoxanthinol, $\mathbf{1 4 4}$ are mediated through different signaling pathways, including the caspases, Bcl-2 proteins, MAPK, PI3K/Akt, JAK/STAT, AP-1, GADD45, and several other molecules that are involved in cell cycle arrest, apoptosis, anti-angiogenesis, or inhibition of metastasis (Figure 32) [214]. 


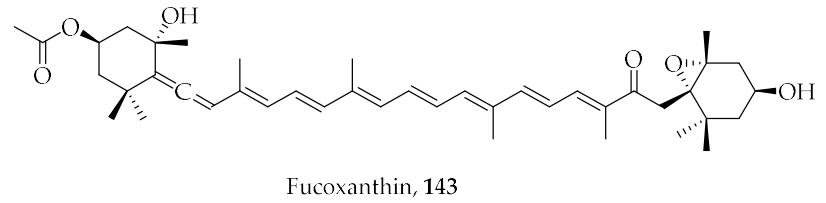

$\begin{array}{ll}\text { Cancer: Bone } & \text { Cancer: Bone } \\ \text { Cancer Cell: Saos-2 } & \text { Cancer Cell: LMB } \\ \text { Biological Targets: PDK1 } & \text { Biological Targets: Akt }\end{array}$

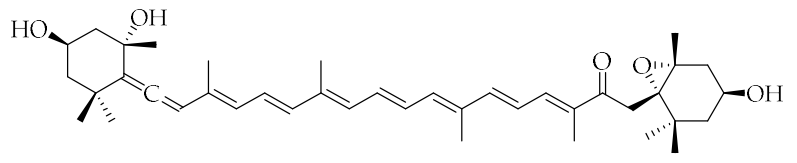

Fucoxanthinol, 144

Cancer: Bone Cancer: Bone

Cancer Cell: Saos-2 Cancer Cell: LMB

Biological Targets: MAPK Biological Targets: GADD45

Figure 32. Structures of the non-provitamin A carotenoid Fucoxanthin and its derivative Fucoxanthinol with a summary of their biological activity towards selected cancer targets.

Carrageenans are linear sulfated polysaccharides extracted from marine red algae, Kappaphycus striatum [215]. The coastal region of Senegal and the Gambia, which is the breeding ground for herrings in West Africa, is said to be very rich in red algae, which also serves as food for the young herrings $[216,217]$. The Senegambian coast is therefore a major source of raw material for the production of carrageenans, which are used as excipients in the food and pharmaceutical industries [217-220]. However, its use has in recent times elicited considerable controversy in view of its perceived harmful effects. Recent investigations have shown that this class of polysaccharides possesses anticancer properties. The carrageenans consist of alternating 3-linked $\beta$-D-galactose and 4-linked $a$-Dgalactose or 4-linked 3,6-anhydro-D-galactose. The carrageenan oligosaccharides exert their anticancer properties by promoting the immune system [221]. The effects of carrageenan oligosaccharides on transplantable tumors and macrophage phagocytosis, quantitative hemolysis of sheep red blood cells (QHS), lymphocyte proliferation, the activity of natural killer cells (NK), production of interleukin-2 (IL-2) and tumor necrosis factor-a (TNF-a), have been studied [215]. They inhibit the growth of transplantable sarcoma S180 and increase macrophage phagocytosis, spleen lymphocyte proliferation, NK cells activity, serumal-IL-2 and TNF-a level in S180-bearing mice [215,221]. Sulphated galactopyranosyl $\lambda, \mathbf{1 4 5}$ and $\kappa, \mathbf{1 4 6}$ carrageenan have been found to inhibit the proliferation of breast, colon, liver, and osteosarcoma cell lines by upregulating proapoptotic factors Caspase- 3,9 and 8 with depression of bax/bal-2 ratio (Figure 33) [215,221].<smiles>CO[C@H]1O[C@H](COS(=O)(=O)O)[C@@H](O[C@H]2O[C@H](CO)[C@@H](O)[C@H](O)[C@H]2OS(=O)(=O)O)[C@H](OS(=O)(=O)O)[C@@H]1O</smiles>

Lambda-Carrageenan, 145

Cancer: Skin

Cancer Cell: B16-F10

Biological Target: IL17A, TNF-a

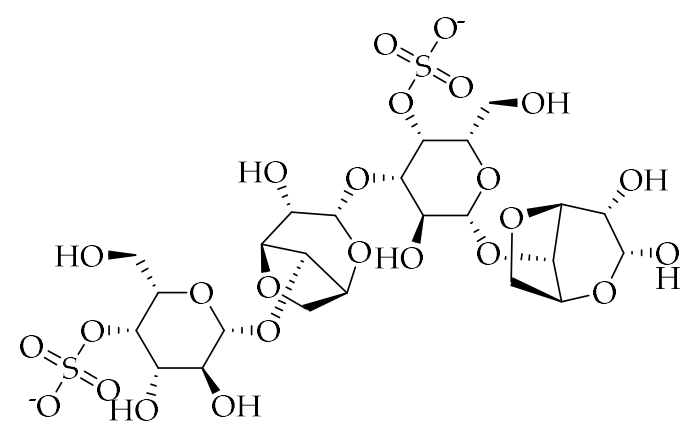

kappa-Carrageenan, 146

Cancer: Leukemia

Cancer Cell: S180

Biological Target: IL-2, TNF-a

Figure 33. Structures of Sulphated galactopyranosyl Lambda-Carrageenan and Kappa-Carrageenan with a summary of their biological activity towards selected cancer targets.

Fucoidan, $\mathbf{1 4 7}$ is a polysaccharide largely made up of L-fucose and sulfate groups isolated from brown algae or sea cucumbers, such as Laminaria digitata, Ascophyllum nodosum, Macrocystis pyrifera, Fucus vesiculosus, and many others (Figure 34) [222]. Compound 147 exhibits a range of bioactivities including antioxidant, anti-tumor, anti-coagulant, antithrombotic, immunoregulatory, anti-viral, and anti-inflammatory effects [222]. The com- 
pound inhibits cancer cells through activating apoptosis. It is reported to increase the levels of reactive oxygen species (ROS), and induce an increase in ATF4, CHOP, and ER stress via modulation of Toll-like receptor 4 in lung cancer cells, leading to apoptosis and inhibition of cell proliferation [223]. It is further reported to induce apoptosis in MDA-MB-231 of breast cancer cells as well as activate caspase-8 and -9 in MCF-7 and HeLa cells [224].

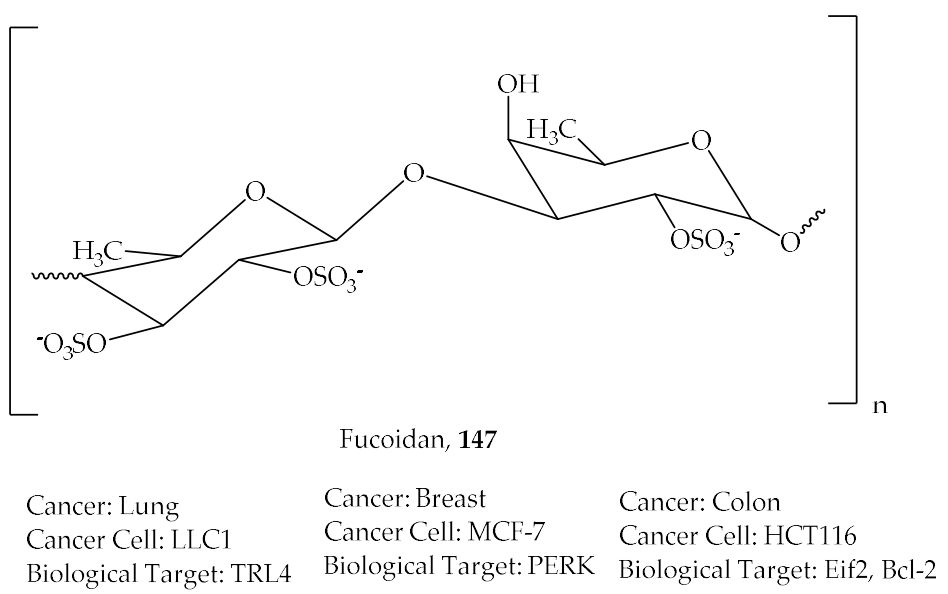

Figure 34. Structure of the polysaccharide Fucoidan with a summary of its biological activity towards selected cancer targets.

Frondaside A, $\mathbf{1 4 8}$ is a triterpenoid glycoside from the Atlantic Sea Cucumber, $\mathrm{Cu}$ cumaria frondose [225]. Cucumarioside A2-2, 149 is also a triterpene glycoside isolated from the Far-Eastern edible sea cucumber, Cucumaria japonica [226]. Both compounds have a broad spectrum of anti-cancer effects, including induction of cellular apoptosis. They inhibit cancer cell growth, migration, invasion, formation of metastases, and angiogenesis [225]. Their cytotoxicity is reported to be through induction of apoptosis by modulation of diverse apoptosis related proteins such as caspase 3, 8, and 9, PARP, and DNA fragmentation [226-228]. Both compounds 148 and 149 suppress cell proliferation, increase stress related proteins like the Janus kinase and p38 mitogen-activated protein kinase as well as induce cell cycle arrest via decrease in cell cycle-related proteins, such as cyclin A and cyclin B (Figure 35) $[229,230]$.

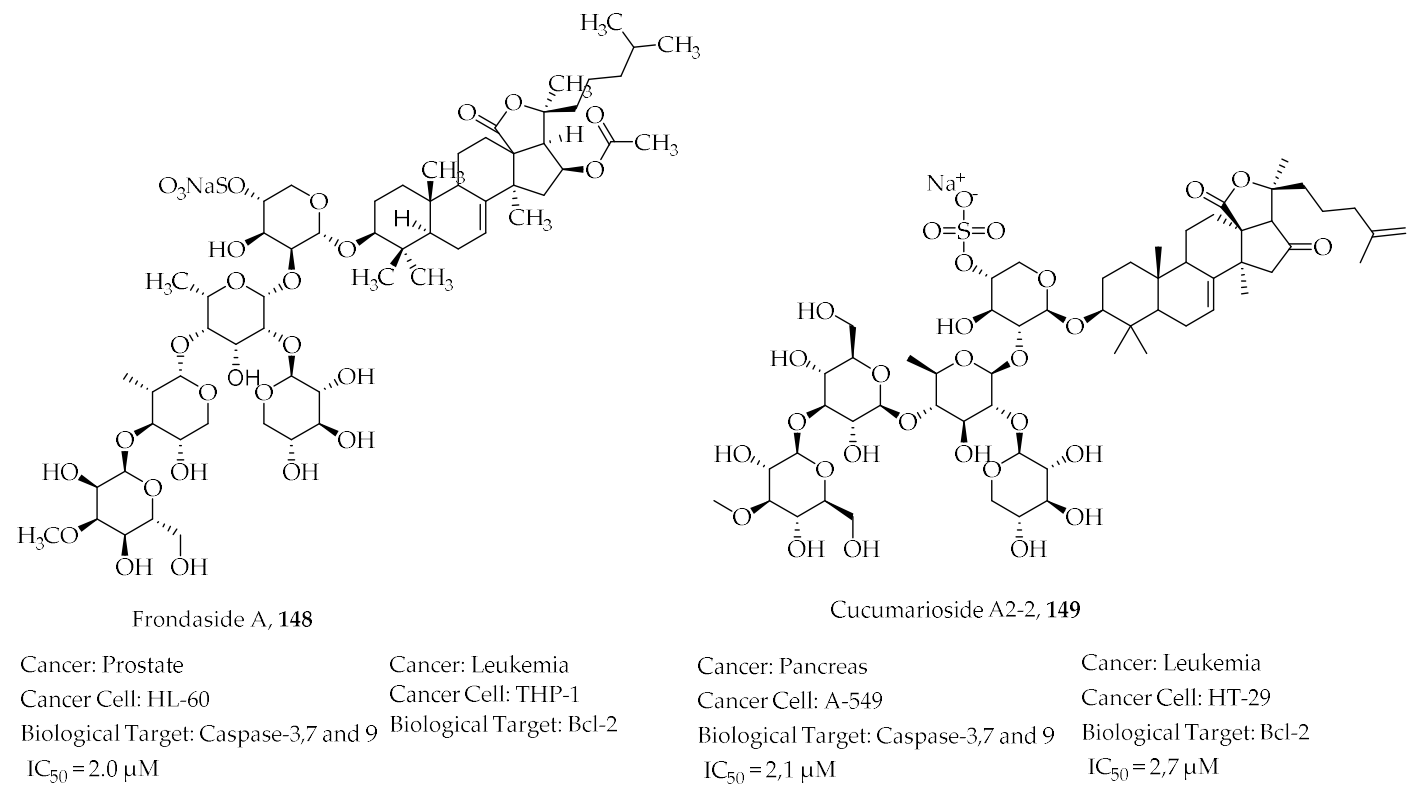

Figure 35. Structures of triterpenoid glycosides Frondaside A and Cucumarioside A2-2 with a summary of their biological activity towards selected cancer targets. 


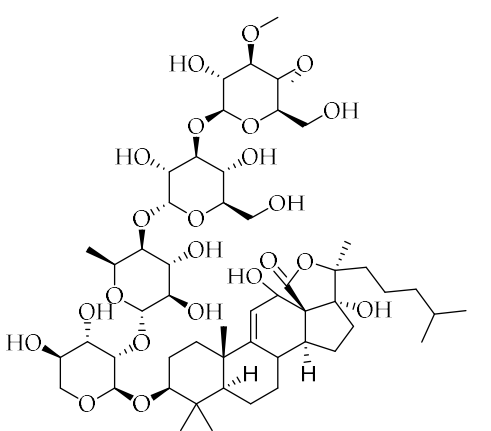

Ds-Echinoside A, 150

Cancer: Liver

Cancer Cell: Hep G2

Biological Targets: VEGF, MMP-9

$\mathrm{IC}_{50}=2.65 \mathrm{uM}$

Ds-echinoside A, $\mathbf{1 5 0}$ isolated from Pearsonothuria graeffei is a non-sulfated triterpene glycoside derived from the desulfurization reaction of echinoside A [231]. Philinopside A, $\mathbf{1 5 1}$ and Philinopside E, $\mathbf{1 5 2}$ on the other hand are sulfated saponins isolated from the sea cucumber, Pentacta quadrangulari (Figure 36) [232,233]. The three compounds all possess a variety of biological activities including antifungal, hemolytic and membranotropic action as well as antiproliferative effects against various human cancer cell lines [234]. They reduce cancer cell adhesion, cell migration, and tube formation [231,235]. Specifically, compounds 151 and 152 reduced the tumor volume by triggering apoptosis of both tumor and tumor-associated endothelial cells via inhibition of angiogenesis-related receptor tyrosine kinases including VEGFR2, FGFR1, and EGFR [232,233]. While compounds 151 and 152 significantly inhibit the proliferation, migration, and tube formation of human microvascular endothelial cells (HMECs) [232,233], 150 on the other hand inhibits the proliferation of human hepatocellular carcinoma cells via MMP9, TIMP-1, and VEGF expression [231].

Figure 36. Structures of a non-sulfated triterpene glycoside Ds-Echinoside A and two sulfated saponins Philinopside A and Philinoside E with a summary of their biological activity towards selected cancer targets.

The Luzonicosides (Luzonicoside A), $\mathbf{1 5 3}$ and Luzonicoside D, $\mathbf{1 5 4}$ are cyclic steroidal glycosides from the starfish Echinaster luzonicus. They affect cell cycle regulation and apoptosis by inhibiting proliferation, the formation of colonies, and the migration of SKMel-28 cells [236]. Aragusterol A, 155 on the other hand is a steroidal epoxide isolated from Okinawan sponge of the genus, Xestospongia [237]. It has been established that cell-cycle hindrance by 155 is dependent on the reduced expression of cyclin-dependent kinase (CDK)s and cyclins involved in the G1-S transition such as CDK2, CDK4, cyclin D1, A, and E (Figure 37) [237].

Heteronemin, 156 is a sesterterpene isolated from the sponge Hyrtios sp [238]. It possesses a pentacyclic scalarane skeleton including a dihydrofuran moiety. Compound 156 induces apoptosis in prostate lymph node carcinoma of the prostate (Lncap) cells via oxidative and ER stress, coupled with the inhibition of topoisomerase II and Hsp90 when evaluated against $\mathrm{K} 652$ cells, targeted NF- $\mathrm{KB}$ upstream protein mitogen-activated protein kinase (MAPK), and engineered tumor necrosis factor (TNF)- $\alpha$-mediated apoptosis [239]. It also promotes apoptotic cell death by inhibiting the phosphorylation of p38 MAPK (Figure 38) [239].

Nagilactone E, 157, a dinorditerpenoid isolated from Podocarpus nagi [240] upregulates the expression of programmed death-ligand 1 (PD-L1) in lung cancer cells through the activation of jun $\mathrm{N}$-terminal kinases (JNK)-c-Jun axis, which has the potential to combine with the PD-1/PD-L1 antibody therapies in lung cancer [240]. It also suppresses transforming growth factor beta 1 (TGF- $\beta 1$ ) stimulated cell migration and invasion. It is also a pur- 
ported protein synthesis inhibitor with strong binding towards serine/threonine-protein kinase (RIOK)2 [241,242]. Furthermore, compound 157 inhibits both cap-dependent and cap-independent translations (Figure 38) [241].

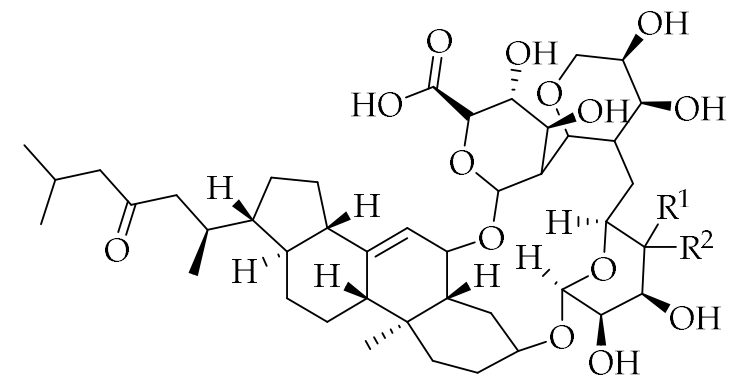

$\mathrm{R}^{1}=\mathrm{OH}, \mathrm{R}^{2}=\mathrm{H}$ Luzonicoside $\mathrm{A}, 153$

$\mathrm{R}^{1}=\mathrm{H}, \mathrm{R}^{2}=\mathrm{H}$ Luzonicoside $\mathrm{D}, 154$

Cancer: Skin

Cancer: Skin

Cancer Cell: RPMI-7951

Cancer Cell: SK-Mel-28

Biological Targets: Bcl-2, p21 Biological Targets:PARP, cyclin D1

$\mathrm{IC}_{50}=119 \mu \mathrm{M}$

$\mathrm{IC}_{50}=160 \mu \mathrm{M}$

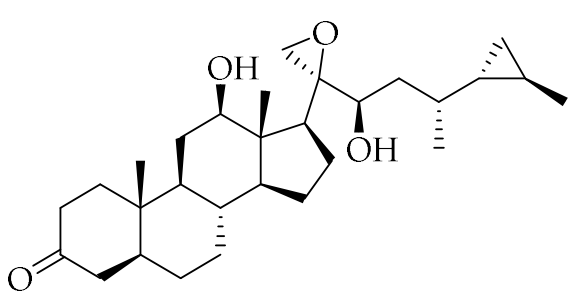

Aragusterol A, 155

Cancer: Lung

Cancer Cell: NSCLC

Biological Targets: CDK

$\mathrm{IC}_{50}=1.65 \mu \mathrm{M}$

Figure 37. Structures of cyclic steroidal glycosides Luzonicoside A, Luzonicoside D, and a steroidal epoxide Aragusterol A with a summary of their biological activity towards selected cancer targets.

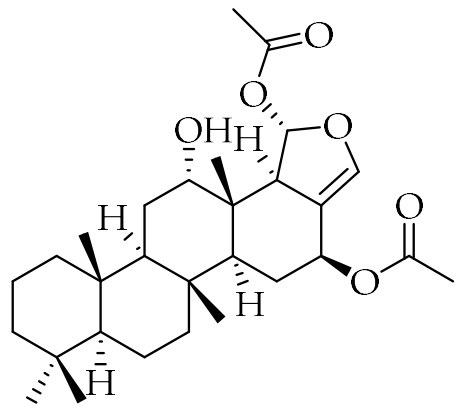

Heteronemin, 156

Cancer: Leukemia

Cancer Cell: K562

Biological Targets: PARP, NF-kB, MAPK

$\mathrm{IC}_{50}=0.4 \mu \mathrm{M}$

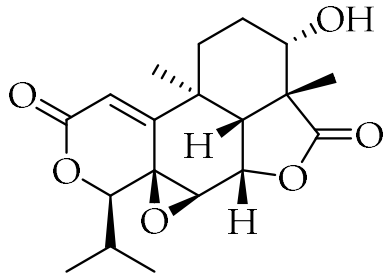

Nagilactone E, 157

Cancer: Lung

Cancer Cell: A549

Biological Target: RIOK2, TGF-B1

Figure 38. Structures of the sesterterpene Heteronemin and the dinorditerpenoid Nagilactone E with a summary of their biological activity towards selected cancer targets.

Marine sponges are known to be a rich source of bioactive natural products. Stelletta, a genus of white marine sponges (Class Demospongiae) is a very rich source of diverse and complex biologically relevant natural products, including alkaloids, terpenoids, peptides, lipids, and steroids. Compounds isolated from this genus include the isomalabaricane-type terpenoids Stelletin A 158, from the marine sponge Stelletta tenuis and Stelletin B, 159 isolated from Jaspis stellifera. The compounds trigger cytoprotective activity through the upregulation of proapoptotic Bax-type (Bak and Bax) protein levels, downregulation of Bcl-2 Akt inhibition in A549, K562 and KU812 cells (Figure 39) [243]. 


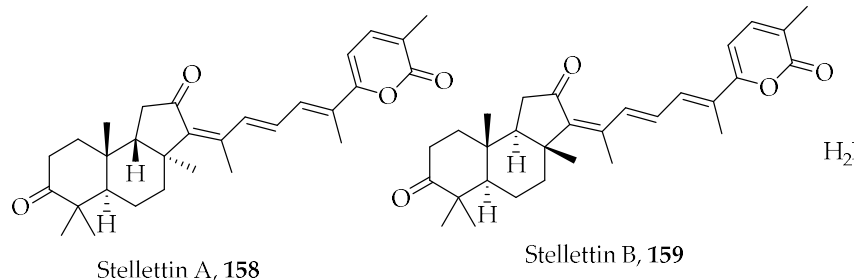

Stellettin A, 158

Cancer: Brain

Cancer Cell: SF295

Biological Targets: Akt, Caspase-3,7, PARP

$\mathrm{IC}_{50}=0.01 \mu \mathrm{M}$

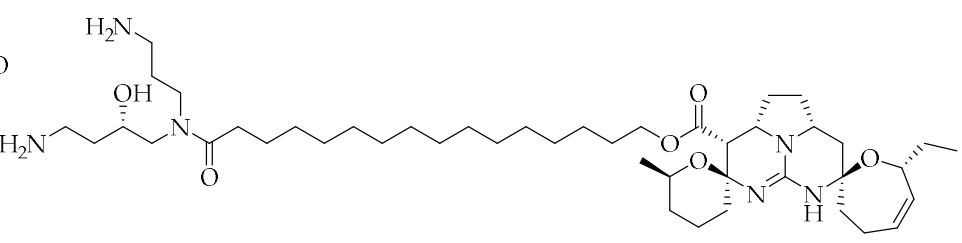

Crambescidin 800,160

$$
\begin{array}{ll}
\text { Cancer: Breast } & \text { Cancer: Breast } \\
\text { Cancer Cell: T11 } & \text { Cancer Cell: MB-231 } \\
\text { Biological Targets: Cyclin D1 } & \text { Biological Targets: MAPK, NF-kB } \\
\mathrm{IC}_{50}=0.07 \mu \mathrm{M} & \mathrm{IC}_{50}=1.57 \mu \mathrm{M}
\end{array}
$$

Figure 39. Structures of the isomalabaricane-type terpenoids Stellettin A and B and a pentacyclic guanidine alkaloid Crambescidin 800 with a summary of their biological activity towards selected cancer targets.

Crambescidin $800, \mathbf{1 6 0}$, is a pentacyclic guanidine alkaloid isolated from the marine sponge Monanchora viridis [244]. It induces cell cycle arrest and apoptosis in triplenegative breast cancer cells. It also activates p53, which in turn inactivates CDK1, resulting in cell-cycle arrest [244-246]. Crambescidin 800 protects HT22 cells against glutamateinduced oxidative toxicity and protects HT22 and neuroblastoma cells from the oxidative stress induced by a hypoxic condition or nitric oxide (NO) (Figure 39) [247]. (19Z)Halichondramide, $\mathbf{1 6 1}$ is a trisoxazole macrolide from the marine sponge chondrosia corticate [245]. It exhibits antiproliferative activity against a variety of cancer cells. For example, it exhibits antimetastatic effect on human prostate cancer cells via modulation of epithelialto-mesenchymal transition [245]. Cytotoxic activity of compound $\mathbf{1 6 1}$ occurs through $\mathrm{Akt} / \mathrm{mTOR}$ pathway suppression and G2/M phase is blocked via an increased expression of p53 and GADD45 proteins (Figure 40) [245].

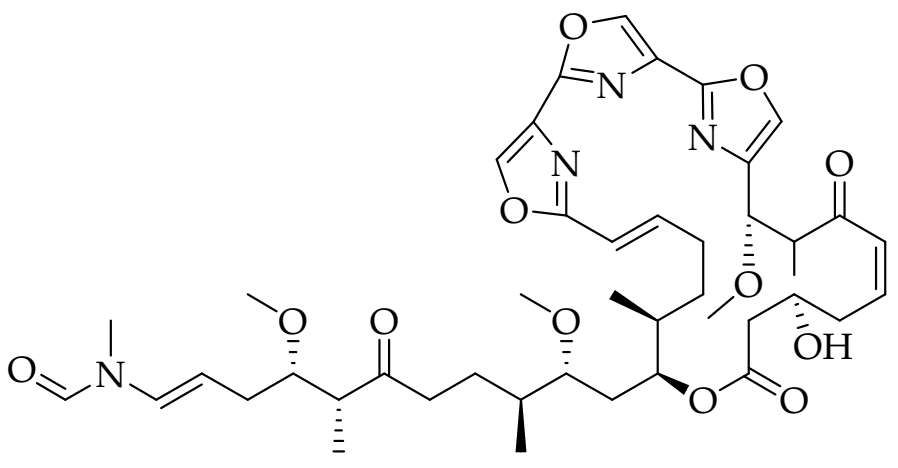

(19Z)-Halichondramide, 161
Cancer: Lung
Cancer: Prostate
Cancer Cell: A549
Cancer Cell: PC3
Biological Targets: CDC2,CDC25C, P5, GADD45alpha
Biological Targets: PRL3, MMP
$\mathrm{IC}_{50}=0.024 \mu \mathrm{M}$
$\mathrm{IC}_{50}=0.81 \mu \mathrm{M}$

Figure 40. Structure of the trisoxazole macrolide (19Z)-Halichondramide with a summary of its biological activity towards selected cancer targets.

The Dichapetalins were first reported as a novel class of triterpenoids from Dichapetalum madagascariensis by Addae-Mensah, Achenbach and their co-workers [248,249]. They are mostly found in the family Dichapetalaceae (Chailletiaceae), but recent reports have confirmed their presence in the Euphorbiaceae, particularly, the genus Phyllanthus [250,251]. To-date, about twenty-six compounds belonging to this novel class of triterpenes have 
been reported mainly from various species of Dichapetalum and a few from Phyllanthus. They are structural derivatives of dammarane characterized by a unique C-6-C-2-unit connection with a variable C-17 side chain mostly containing spirolactone, lactone, lactol, acetal, methyl ester, or furan moieties. The cytotoxic activity of the dichapetalins was first reported by Achenbach et al. who found that dichapetalin A, 165 exhibited very strong in vitro cytotoxicity about seven times greater than that of podophyllotoxin [248]. They also found the compound to inhibit L1210 murine leukemia cells at extremely low doses $\left(\mathrm{EC}_{90}<0.0001 \mu \mathrm{g} / \mathrm{mL}\right.$ but its sensitivity on human $\mathrm{KB}$ carcinoma and murine bone marrow stimulated with GM-CSF was at concentrations four-fold higher [248]. Although the cytotoxicity and cancer cell growth inhibition of the dichapetalins are well known, their biological targets of inhibition are yet to be fully elucidated. An investigation by Long et al. assayed the cytotoxic and anti-proliferative properties of ten dichapetalins against human colorectal carcinoma (HCT116) and human melanoma (WM 266-4) cells and found dichapetalins $\mathrm{M}, \mathbf{1 6 2}$ and $\mathrm{P}, \mathbf{1 6 3}$ as the most potent, displaying activities in the $10^{-7}$ to $10^{-8} \mathrm{M}$ range [252]. Osei-Safo et al. isolated a novel derivative of dichapetalin $\mathrm{P}$, 164 and two others known dichapetalins X, 165 and A, 166 (Figure 41) from Dichapetalum pallidum and investigated their antiproliferative effects against the human T-lymphocytic leukemia (Jurkat), acute promyelocytic leukemia (HL-60) and T-lymphoblast-like leukemia (CEM) cell lines [253]. All the three isolates were significantly bioactive, but dichapetalin $\mathrm{X}$ was found to be the most potent against all three cell lines with $\mathrm{IC}_{50}$ of $3.14 \mu \mathrm{M}$ [253]. Similarly, four new dichapetalins (Pacidusin A, B, C, and D) (Figure 41), 167-170 were recently isolated from young leaves of Phyllanthus acidus and their cytotoxic activities evaluated [254]. While all the isolated dichapetalins showed moderate activity against BEAS-2B and LO2 normal cell lines with $\mathrm{IC}_{50}$ less than $22.55 \mu \mathrm{M}$, they exhibited strong cytotoxic activities against five human cancer cell lines with $\mathrm{IC}_{50}$ ranging between 3.38 and $22.38 \mu \mathrm{M}$ [254].
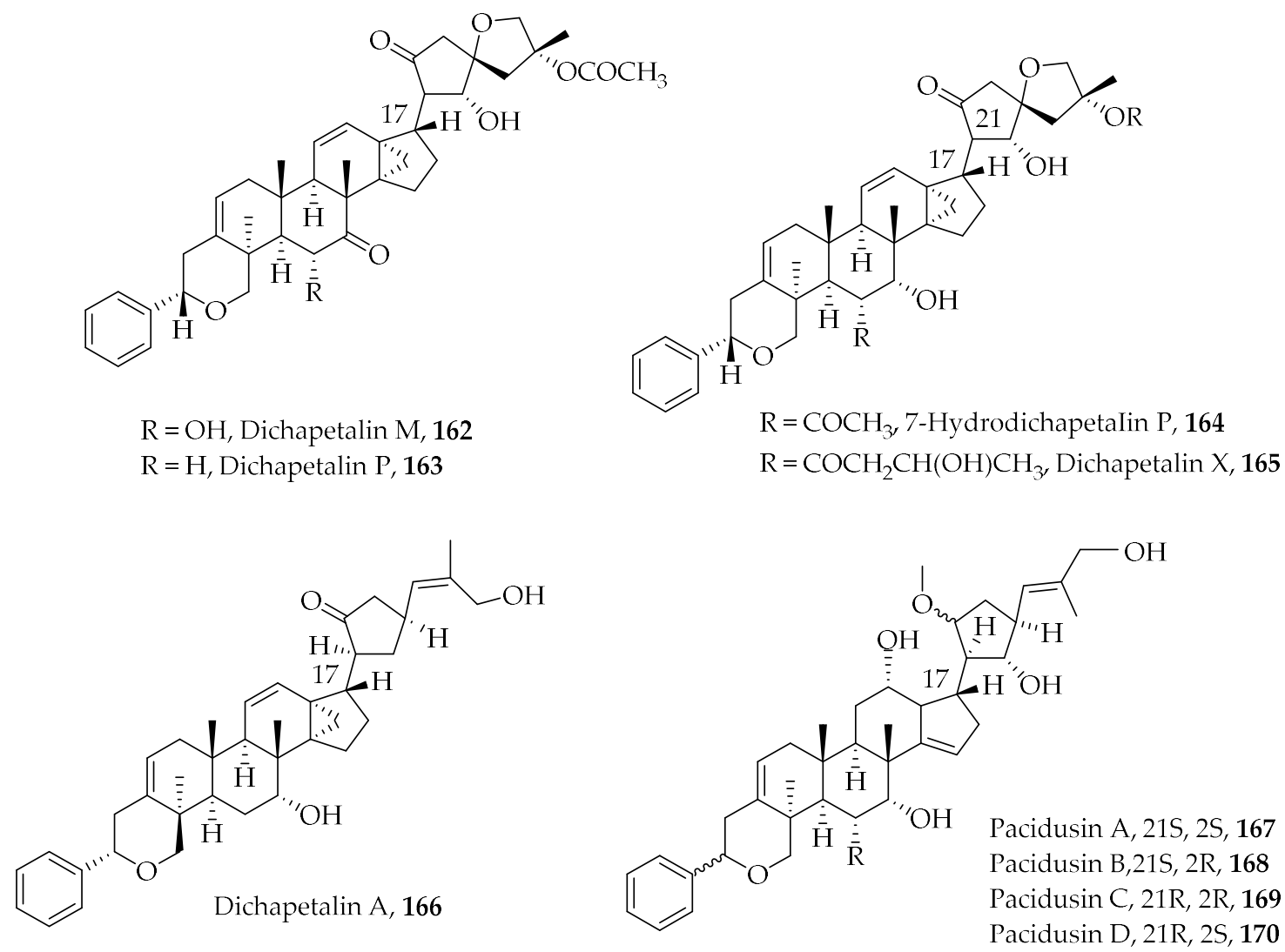

Figure 41. Structures of the triterpenoids Dichapetalins M, P, X and A, 7-Hydroxydichapetalin P, as well as Pacidusins A-D. 
The nutritional benefits of some species belonging to the Kingdom Fungi such as mushroom, Rhizopus, morels, etc. are enormous and are well documented [255]. Recent studies have also found fungi to possess numerous natural products with diverse medicinal properties for the treatment of infectious and non-infectious diseases [256]. Two potent inhibitors of NF- $\mathrm{kB}$ function isolated from the fungus family, panepoxydone, 171 and oxasporidion, $\mathbf{1 7 2}$ induced apoptotic proteins and inhibited TNF- $\alpha[257,258]$. Compound $\mathbf{1 7 1}$ was isolated from Lentinus crinitus (an edible mushroom) while compound $\mathbf{1 7 2}$ was isolated as a mixture of four isomers from fermentations of the ascomycete Chaetomium subspirale (Figure 42) [257,258].<smiles>CC(C)=CC(O)C1=C[C@H](O)C2OC2C1=O</smiles>

Panepoxydone, $\mathbf{1 7 1}$

\section{Cancer: Breast \\ Cancer Cell: MCF-7 \\ Biological Targets: NF-kB \\ $\mathrm{IC}_{50}=2.5 \mu \mathrm{M}$ \\ Cancer: Breast \\ Cancer Cell: TNBC (MDAM-453) \\ Biological Targets: FOXM1, Bax, PARP \\ $\mathrm{IC}_{50}=2.0 \mu \mathrm{M}$}<smiles>C/C=C/C1C=CC(=O)C(O)C12C(=O)OC(C)C2=O</smiles>

Oxaspirodion, $\mathbf{1 7 2}$

Cancer: Bone

Cancer Cell: HeLa

Biological Targets: ERK

$\mathrm{IC}_{50}=10 \mu \mathrm{M}$

Figure 42. Structures of Panepoxydone and Oxasporidion with a summary of their biological activity towards selected cancer targets.

Candidaspongiolide, $\mathbf{1 7 3}$ is a polyketide extracted from Candidaspongia sp [259]. It inhibits protein synthesis and induces apoptosis in both U251 and HCT116 cells, the latter in part by a caspase 12-dependent pathway [259]. In addition, compound 173 inhibits proliferation of human melanoma cells in a selective manner compared to breast and lung cancer cell lines (Figure 43) [260].

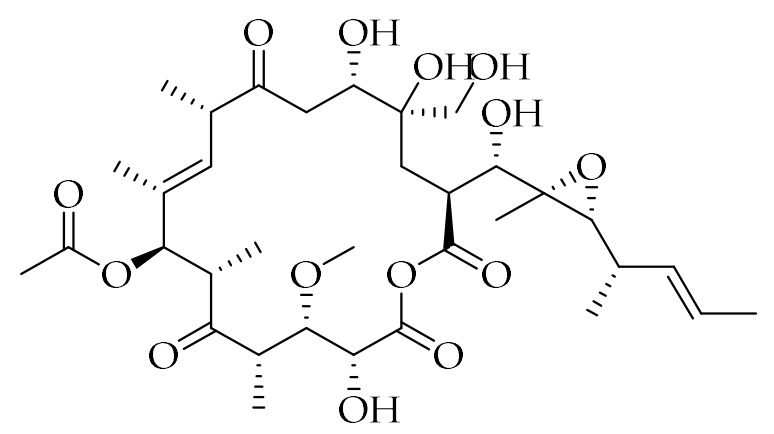

Candidaspongiolide, $\mathbf{1 7 3}$

Cancer: Brain

Cancer Cell: U251

Biological Targets: Elf2, PKRalpha Biological Targets: JNK, Caspase-3,8,9 and 12
Cancer: Colorectal

Cancer Cell: HCT116

$$
\mathrm{IC}_{50}=0.1 \mu \mathrm{M}
$$

Figure 43. Structure of the polyketide Candidaspongiolide with a summary of its biological activity towards selected cancer targets.

Ophiobolin $\mathrm{O}, \mathbf{1 7 4}$ is a fungal metabolite. It is a sestertepenoid belonging to the ophiobolane group of terpenoids isolated from Aspergillus ustus [261]. It is a potent anti- 
tumor drug for human breast cancer [262]. It induces G1 phase arrest in human breast cancer when tested on the Michigan cancer foundation (MCF)-7 cells and reduces the phosphorylation level of protein kinase B (AKT) and Glycogen synthase kinase-3 $\beta$ (GSK3 $\beta$ ). It also induces down-regulation of cyclin D1 [262]. Incubation of $\mathbf{1 7 4}$ with glioblastoma cancer cells resulted in the induction of the death of the glioblastoma cells as a result of G0/G1 cell cycle arrest and $\mathrm{Ca}^{2+}$-activated $\mathrm{K}^{+}$channel (BKCa) ion channel activity inhibition (Figure 44) [261,262].

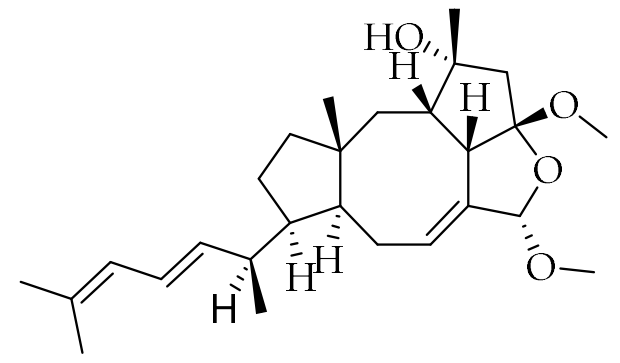

Ophiobolin O, 174

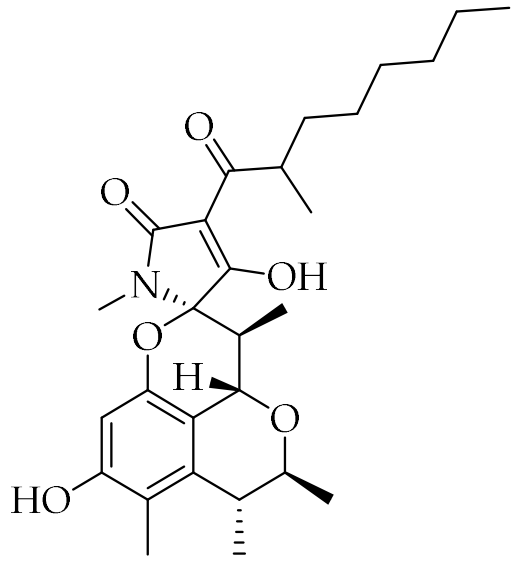

Penicitrinine A, $\mathbf{1 7 5}$

Cancer: Breast

Cancer: Melanoma

Cancer Cell: MCF-7

Cancer Cell: A-375 cells

Biological Targets: Bcl-2, ERK, P38, MAPK, JNK

Biological Targets: Bl-2, Bax, MMP-9

$\mathrm{IC}_{50}=17.86 \mu \mathrm{M}$

Figure 44. Structures of the sestertepenoid Ophiobolin and the spiro alkaloid Penicitrinine A with a summary of their biological activity towards selected cancer targets.

Penicitrinine A, $\mathbf{1 7 5}$ is an alkaloid with a unique spiro skeleton, isolated from a marinederived fungus Penicillium citrinum. It showed toxicity against cellosaurus cell line A-375, human cell lines SPC-A1 and HGC-27, and human cancer cell lines with $\mathrm{IC}_{50}$ values of $20.1,28.6$ and $29.4 \mu \mathrm{M}$, respectively [263]. The anti-metastatic activity is purported to be by decreasing the expression of Bcl-2 and increasing the expression of Bax [263]. Furthermore, compound 175 suppresses metastatic activity of A-375 cells by regulating the expression of matrix metallopeptidase 9 (MMP-9) and its specific tissue inhibitor of metalloproteinase 1 (TIMP-1) (Figure 44) [263].

Salinomycin, $\mathbf{1 7 6}$ is a monocarboxylic polyether antibiotic isolated from Streptomyces albus strain (Figure 45) [264,265]. Although the exact mechanism of its anticancer action is unknown, $\mathbf{1 7 6}$ is suspected to decrease the expression of adenosine triphosphate-binding cassette transporter and interfere with the protein kinase B (Akt) signaling pathway [264]. Salinomycin suppresses the phosphorylation of low-density lipoprotein receptor-related protein 6 (LRP6) and the expression of $\beta$-catenin and glycogen synthase kinase- $3 \beta$ (p-GSK-3 $\beta$ ). Additionally, it induces the production of ROS and mitochondrial membrane depolarization resulting in the activation of caspase 3. It also causes the induction of poly(ADP-ribose) polymerase-1 (PARP-1) cleavage, and the elicitation of DNA damage [264]. Consequently, induction of tumor cell death results leading to inhibition of cancer cell growth. The compound also induces autophagic cell death, inhibits the NF-kB pathway and activates p38 mitogen-activated protein kinase (MARK) pathway [266]. 


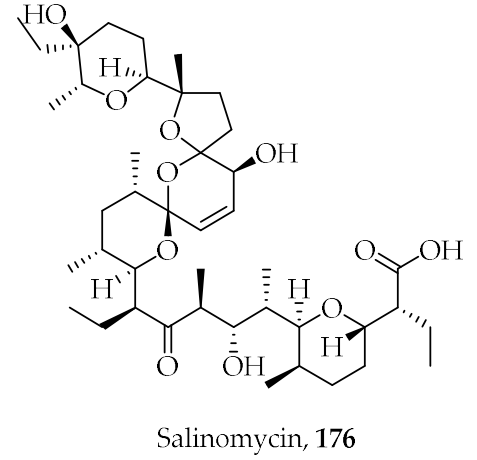

Cancer: Breast

Cancer Cell: MCF-7

Cancer: Leukemia

Cancer Cell: MDR

Biological Targets: Akt, Wnt/beta-catenin, P-gp Biological Targets: Bcl-2, NF-kB

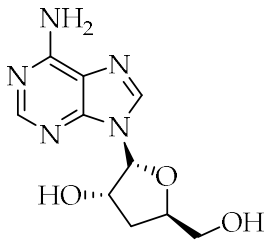

Cordycepin, 177

Figure 45. Structures of the monocarboxylic polyether Salinomycin and the nucleoside antimetabolite Cordycepin with a summary of their biological activity towards selected cancer targets.

Cordycepin, 177, a nucleoside antimetabolite from Cordyceps militaris [267] is an adenosine analogue which is readily phosphorylated to its mono-, di- and tri-phosphate derivatives intracellularly [268]. Compound 177 kills cancer cells resistant to pro-apoptotic stimuli, induces non-apoptotic-related death pathways in cancer cells, and impairs the biology of cancer stem cells (CSCs) [269]. It also causes cell cycle arrest but in the G2/M phase by regulating c-Jun N-terminal kinase activation and TNF $\alpha$-induced NF- $\mathrm{\kappa B}$ activation $[267,268]$.

Other oxygen heterocyclic compounds which have been screened for multi-target anticancer properties are the oxindole-benzofuran hybrids. Compounds 178-180 were found to possess activity against breast cancer when tested against CDK2/GSK-3 $\beta$. They were found to be more potent in comparison with staurosporine, 181, a cell permeable alkaloid isolated from Streptomyces staurosporeus [270]. The $\mathrm{IC}_{50}$ values against MCF-7 cell lines were $3.41 \mu \mathrm{M}$ (178), $3.45 \mu \mathrm{M}$ (179), $2.27 \mu \mathrm{M}$ (180), and $4.81 \mu \mathrm{M}$ (179). When tested against breast cancer cell line T-47D, activities of $3.82,4.53$ and $7.80 \mu \mathrm{M}$, for compounds 178,179 and 180 , respectively were obtained while that of 181 was $4.34 \mu \mathrm{M}$. Compounds 179 and 180 were found to inhibit CDK2/GSK-3 $\beta$ resulting in cell cycle arrest in the G2/M phase (Figure 46) [270].<smiles>[R]c1cc([Y])c2c(c1)/C(=N/NC(=O)c1cc3cc(Br)ccc3o1)C(=O)N2</smiles>

$$
\begin{aligned}
& \mathrm{R}=\mathrm{Br}, \mathrm{R}_{1}=\mathrm{H}, \mathbf{1 7 8} \\
& \mathrm{R}=\mathrm{CH}_{3}, \mathrm{R}_{1}=\mathrm{H}, \mathbf{1 7 9} \\
& \mathrm{R}=\mathrm{OCH}_{3}, \mathrm{R}_{1}=\mathrm{H}, \mathbf{1 8 0}
\end{aligned}
$$<smiles>CN[C@H]1C[C@H]2O[C@](C)(C1OC)n1c3ccccc3c3c4c(c5c6ccccc6n2c5c31)C(=O)NC4</smiles>

Staurosporine, $\mathbf{1 8 1}$

Figure 46. Structures of oxindole-benzofuran hybrids 162-164 and the bis-indole Staurosporine with a summary of their biological activity towards selected cancer targets. 


\section{Conclusions}

Chemotherapy is among the various strategies available for cancer treatment. However, many of the available chemotherapeutic agents suffer serious drawbacks including drug inefficiencies, resistance, and diverse and intertwining pathways of the pathogenesis of cancer diseases. Multi-target drugs have been proposed as the effective means of treating cancers. In this review, different classes of synthetic, semisynthetic, and naturally occurring heterocyclic compounds with multi-targeting properties have been evaluated as potential chemotherapeutic agents for various forms of cancer. The classes of heterocyclics considered in this review are the nitrogen, sulfur, oxygen, combined nitrogen/sulfur, and nitrogen/oxygen heterocyclics. The mode of action of these compounds includes inhibition of cell growth, induction of apoptosis and reduction of cell metastasis via downregulation of topoisomerase I and II, G2/M and G0/G1 cell cycle arrest, HDAC, tubulin polymerization, VEGFR, and EGFR. Some of the heterocyclic compounds also suppress NF-kB, STAT3, P13K/AKT, BRAF, and MDR.

Author Contributions: Conceptualization of the project: I.A.-M., R.K.A., D.O.-S. and P.O.S.; Research and collection of material for the project: P.O.S., R.K.A., I.A.-M. and D.O.-S.; Drafting of the manuscript: P.O.S., R.K.A., I.A.-M. and D.O.-S.; Comprehensive editing and finalization of the manuscript: I.A.-M., R.K.A., P.O.S. and D.O.-S. All authors have read and agreed to the published version of the manuscript.

Funding: This research received no external funding.

Institutional Review Board Statement: Not applicable.

Informed Consent Statement: Not applicable.

Data Availability Statement: Not applicable.

Acknowledgments: We acknowledge with thanks and appreciation the award of a postgraduate scholarship to Patrick Opare Sakyi by the Ghana National Petroleum Corporation (GNPC).

Conflicts of Interest: The authors have no issues of conflict of interest regarding to the manuscript and its contents.

\section{References}

1. Dhiman, N.; Kaur, K.; Jaitak, V. Tetrazoles as anticancer agents: A review on synthetic strategies, mechanism of action and SAR studies. Bioorg. Med. Chem. 2020, 28, 115599. [CrossRef]

2. Abbot, V.; Sharma, P.; Dhiman, S.; Noolvi, M.N.; Patel, H.M.; Bhardwaj, V. Small hybrid heteroaromatics: Resourceful biological tools in cancer research. RSC Adv. 2017, 7, 28313-28349. [CrossRef]

3. Ali, I.; Lone, M.N.; Aboul-Enein, H.Y. Imidazoles as potential anticancer agents. MedChemComm 2017, 8, 1742-1773. [CrossRef]

4. Sung, H.; Ferlay, J.; Siegel, R.L.; Laversanne, M.; Soerjomataram, I.; Jemal, A.; Bray, F. Global cancer statistics 2020: GLOBOCAN estimates of incidence and mortality worldwide for 36 cancers in 185 countries. CA Cancer J. Clin. 2021, 71, 209-249. [CrossRef]

5. Yee, E.M.H.; Pasquier, E.; Iskander, G.; Wood, K.; Black, D.S.; Kumar, N. Synthesis of novel isoflavene-propranolol hybrids as anti-tumor agents. Bioorg. Med. Chem. 2013, 21, 1652-1660. [CrossRef]

6. Dorak, M.T.; Karpuzoglu, E. Gender differences in cancer susceptibility: An inadequately addressed issue. Front. Genet. 2012, 3, 1-11. [CrossRef]

7. Edgren, G.; Liang, L.; Adami, H.O.; Chang, E.T. Enigmatic sex disparities in cancer incidence. Eur. J. Epidemiol. 2012, 27, 187-196. [CrossRef] [PubMed]

8. Hanahan, D.; Folkman, J. Patterns and emerging mechanisms of the angiogenic switch during tumorigenesis. Cell 1996, 86, 353-364. [CrossRef]

9. Zuazo-Gaztelu, I.; Casanovas, O. Unraveling the role of angiogenesis in cancer ecosystems. Front. Oncol. 2018, 8, 248. [CrossRef] [PubMed]

10. Teleanu, R.I.; Chircov, C.; Grumezescu, A.M.; Teleanu, D.M. Tumor Angiogenesis and Anti-Angiogenic Strategies for Cancer Treatment. J. Clin. Med. 2019, 9, 84. [CrossRef]

11. De la Cruz-López, K.G.; Castro-Muñoz, L.J.; Reyes-Hernández, D.O.; García-Carrancá, A.; Manzo-Merino, J. Lactate in the Regulation of Tumor Microenvironment and Therapeutic Approaches. Front. Oncol. 2019, 9, 1143. [CrossRef] [PubMed]

12. Kuczynski, E.A.; Vermeulen, P.B.; Pezzella, F.; Kerbel, R.S.; Reynolds, A.R. Vessel co-option in cancer. Nat. Rev. Clin. Oncol. 2019, 16, 469-493. [CrossRef] 
13. Lee, S.Y.; Ju, M.K.; Jeon, H.M.; Jeong, E.K.; Lee, Y.J.; Kim, C.H.; Park, H.G.; Han, S.I.; Kang, H.S. Regulation of Tumor Progression by Programmed Necrosis. Oxidative Med. Cell. Longev. 2018, 2018, 3537471. [CrossRef] [PubMed]

14. Tomes, L.; Emberley, E.; Niu, Y.; Troup, S.; Pastorek, J.; Strange, K.; Harris, A.; Watson, P.H. Necrosis and hypoxia in invasive breast carcinoma. Breast Cancer Res. Treat. 2003, 81, 61-69. [CrossRef]

15. Angiogenesis Inhibitors-National Cancer Institute. Available online: https://www.cancer.gov/about-cancer/treatment/types/ immunotherapy/angiogenesis-inhibitors-fact-sheet (accessed on 14 February 2021).

16. Saman, H.; Raza, S.S.; Uddin, S.; Rasul, K. Inducing angiogenesis, a key step in cancer vascularization, and treatment approaches. Cancers 2020, 12, 1172. [CrossRef]

17. Sun, L.; Fan, G.; Shan, P.; Qiu, X.; Dong, S.; Liao, L.; Yu, C.; Wang, T.; Gu, X.; Li, Q.; et al. Regulation of energy homeostasis by the ubiquitin-independent REG $\gamma 3$ proteasome. Nat. Commun. 2016, 7, 1-15. [CrossRef]

18. Kania, E.; Pająk, B.; Orzechowski, A. Calcium homeostasis and ER stress in control of autophagy in cancer cells. Biomed. Res. Int. 2015, 2015, 352794. [CrossRef] [PubMed]

19. Isoldi, M.; Visconti, M.; Castrucci, A. Anti-Cancer Drugs: Molecular Mechanisms of Action. Mini-Rev. Med. Chem. 2005, 5, 685-695. [CrossRef] [PubMed]

20. Kumar, B.; Singh, S.; Skvortsova, I.; Kumar, V. Promising Targets in Anti-cancer Drug Development: Recent Updates. Curr. Med. Chem. 2017, 24, 4729-4752. [CrossRef] [PubMed]

21. Magalhaes, L.G.; Ferreira, L.L.G.; Andricopulo, A.D. Recent advances and perspectives in cancer drug design. Anais da Academia Brasileira de Ciências 2018, 1233-1250. [CrossRef]

22. Lugano, R.; Ramachandran, M.; Dimberg, A. Tumor angiogenesis: Causes, consequences, challenges and opportunities. Cell. Mol. Life Sci. 2020, 77, 1745-1770. [CrossRef] [PubMed]

23. Liu, J.; Ming, B.; Gong, G.H.; Wang, D.; Bao, G.L.; Yu, L.J. Current research on anti-breast cancer synthetic compounds. RSC Adv. 2018, 8, 4386-4416. [CrossRef]

24. Dembitsky, V.M.; Gloriozova, T.A.; Poroikov, V.V. Pharmacological profile of natural and synthetic compounds with rigid adamantane-based scaffolds as potential agents for the treatment of neurodegenerative diseases. Biochem. Biophys. Res. Commun. 2020, 529, 1225-1241. [CrossRef]

25. Ahuja, A.; Kim, J.H.; Kim, J.H.; Yi, Y.S.; Cho, J.Y. Functional role of ginseng-derived compounds in cancer. J. Ginseng Res. 2018, 42, 248-254. [CrossRef] [PubMed]

26. Lee, M.M.L.; Chan, B.D.; Wong, W.Y.; Leung, T.W.; Qu, Z.; Huang, J.; Zhu, L.; Lee, C.S.; Chen, S.; Tai, W.C.S. Synthesis and Evaluation of Novel Anticancer Compounds Derived from the Natural Product Brevilin A. ACS Omega 2020, 5, 14586-14596. [CrossRef] [PubMed]

27. Perks, C.M.; Keith, A.J.; Goodhew, K.L.; Savage, P.B.; Winters, Z.E.; Holly, J.M.P. Prolactin acts as a potent survival factor for human breast cancer cell lines. Br. J. Cancer 2004, 91, 305-311. [CrossRef] [PubMed]

28. Kozako, T.; Suzuki, T.; Yoshimitsu, M.; Arima, N.; Honda, S.I.; Soeda, S. Anticancer agents targeted to sirtuins. Molecules 2014, 19, 20295-20313. [CrossRef] [PubMed]

29. Paik, E.S.; Kim, T.H.; Cho, Y.J.; Ryu, J.; Choi, J.J.; Lee, Y.Y.; Kim, T.J.; Choi, C.H.; Kim, W.Y.; Sa, J.K.; et al. Preclinical assessment of the VEGFR inhibitor axitinib as a therapeutic agent for epithelial ovarian cancer. Sci. Rep. 2020, 10, 1-9. [CrossRef]

30. Wang, J.; Li, M.; Cui, X.; Lv, D.; Jin, L.; Khan, M.; Ma, T. Brevilin A promotes oxidative stress and induces mitochondrial apoptosis in U87 glioblastoma cells. OncoTargets Ther. 2018, 11, 7031-7040. [CrossRef]

31. Chen, X.; Du, Y.; Nan, J.; Zhang, X.; Qin, X.; Wang, Y.; Hou, J.; Wang, Q.; Yang, J. Brevilin A, a Novel Natural Product, Inhibits Janus Kinase Activity and Blocks STAT3 Signaling in Cancer Cells. PLoS ONE 2013, 8, e63697. [CrossRef]

32. Navya, P.N.; Kaphle, A.; Srinivas, S.P.; Bhargava, S.K.; Rotello, V.M.; Daima, H.K. Current trends and challenges in cancer management and therapy using designer nanomaterials. Nano Converg. 2019, 6, 1-30. [CrossRef] [PubMed]

33. Vasir, J.K.; Vinod, L. Targeted Drug Delivery in Cancer Therapy. Technol. Cancer Res. Treat. 2005, 4, 363-374. [CrossRef] [PubMed]

34. Feitelson, M.A.; Arzumanyan, A.; Kulathinal, R.J.; Blain, S.W.; Holcombe, R.F.; Mahajna, J.; Marino, M.; Martinez-Chantar, M.L.; Nawroth, R.; Sanchez-Garcia, I.; et al. Sustained proliferation in cancer: Mechanisms and novel therapeutic targets. Semin. Cancer Biol. 2015, 35, S25-S54. [CrossRef] [PubMed]

35. Modi, S.J.; Kulkarni, V.M. Vascular Endothelial Growth Factor Receptor (VEGFR-2)/KDR Inhibitors: Medicinal Chemistry Perspective. Med. Drug Discov. 2019, 2, 100009. [CrossRef]

36. Dratkiewicz, E.; Pietraszek-Gremplewicz, K.; Simiczyjew, A.; Mazur, A.J.; Nowak, D. Gefitinib or lapatinib with foretinib synergistically induce a cytotoxic effect in melanoma cell lines. Oncotarget 2018, 9, 18254-18268. [CrossRef]

37. Segovia-Mendoza, M.; González-González, M.E.; Barrera, D.; Díaz, L.; García-Becerra, R. Efficacy and mechanism of action of the tyrosine kinase inhibitors gefitinib, lapatinib and neratinib in the treatment of her2-positive breast cancer: Preclinical and clinical evidence. Am. J. Cancer Res. 2015, 5, 2531-2561.

38. Harris, J.D.; Quatman, C.E.; Manring, M.M.; Siston, R.A.; Flanigan, D.C. How to write a systematic review. Am. J. Sports Med. 2014, 42, 2761-2768. [CrossRef]

39. Moher, D.; Liberati, A.; Tetzlaff, J.; Altman, D.G. Reprint-Preferred Reporting items for systematic reviews and meta-analyses: The PRISMA statement. Phys. Ther. 2009, 89, 873-880. [CrossRef]

40. Marson, C.M. Saturated Heterocycles with Applications in Medicinal Chemistry. Adv. Heterocycl. Chem. 2016, 121, 13-33. [CrossRef] 
41. Paudel, A.; Hamamoto, H.; Panthee, S.; Kaneko, K.; Matsunaga, S.; Kanai, M.; Suzuki, Y.; Sekimizu, K. A novel spiro-heterocyclic compound identified by the silkworm infection model inhibits transcription in Staphylococcus aureus. Front. Microbiol. 2017, 8, 712. [CrossRef]

42. Ali, S.M.; Siddiqui, R.; Ong, S.K.; Shah, M.R.; Anwar, A.; Heard, P.J.; Khan, N.A. Identification and characterization of antibacterial compound(s) of cockroaches (Periplaneta americana). Appl. Microbiol. Biotechnol. 2017, 101, 253-286. [CrossRef] [PubMed]

43. Khatoon, H.; Abdulmalek, E. Novel Synthetic Routes to Prepare Biologically Active Quinoxalines and Their Derivatives: A Synthetic Review for the Last Two Decades. Molecules 2021, 26, 1055. [CrossRef]

44. Rashid, M.; Shrivastava, N.; Husain, A. Synthesis and SAR Strategy of Thiazolidinedione: A Novel Approach for Cancer Treatment. J. Chil. Chem. Soc. 2020, 65, 4817-4832. [CrossRef]

45. Abdelsalam, M.A.; Aboulwafa, O.M.; Badawey, E.S.A.M.; El-Shoukrofy, M.S.; El-Miligy, M.M.; Gouda, N. Design and synthesis of some $\beta$-carboline derivatives as multi-target anticancer agents. Future Med. Chem. 2018, 10, 2791-2814. [CrossRef]

46. Jiang, Y.; Li, X.; Li, X.; Hou, J.; Ding, Y.; Zhang, J.; Xu, W.; Zhang, Y. Discovery of Multi-target Anticancer Agents Based on HDAC Inhibitor MS-275 and 5-FU. Med. Chem. 2016, 12, 30-36. [CrossRef]

47. Ribatti, D. Judah Folkman, a pioneer in the study of angiogenesis. Angiogenesis 2008, 11, 3-10. [CrossRef] [PubMed]

48. Guan, X.W.; Xu, X.H.; Feng, S.L.; Tang, Z.B.; Chen, S.W.; Hui, L. Synthesis of hybrid 4-deoxypodophyllotoxin-5-fluorouracil compounds that inhibit cellular migration and induce cell cycle arrest. Bioorg. Med. Chem. Lett. 2016, 26, 1561-1566. [CrossRef]

49. Peng, F.W.; Xuan, J.; Wu, T.T.; Xue, J.Y.; Ren, Z.W.; Liu, D.K.; Wang, X.Q.; Chen, X.H.; Zhang, J.W.; Xu, Y.G.; et al. Design, synthesis and biological evaluation of $\mathrm{N}$-phenylquinazolin-4-amine hybrids as dual inhibitors of VEGFR-2 and HDAC. Eur. J. Med. Chem. 2016, 109, 1-12. [CrossRef] [PubMed]

50. Punganuru, S.R.; Madala, H.R.; Venugopal, S.N.; Samala, R.; Mikelis, C.; Srivenugopal, K.S. Design and synthesis of a C7-aryl piperlongumine derivative with potent antimicrotubule and mutant p53-reactivating properties. Eur. J. Med. Chem. 2016, 107, 233-244. [CrossRef]

51. Elzahhar, P.A.; Abd El Wahab, S.M.; Elagawany, M.; Daabees, H.; Belal, A.S.F.; EL-Yazbi, A.F.; Eid, A.H.; Alaaeddine, R.; Hegazy, R.R.; Allam, R.M.; et al. Expanding the anticancer potential of 1,2,3-triazoles via simultaneously targeting Cyclooxygenase-2, 15-lipoxygenase and tumor-associated carbonic anhydrases. Eur. J. Med. Chem. 2020, 200, 112439. [CrossRef]

52. Dragovich, T.; Laheru, D.; Dayyani, F.; Bolejack, V.; Smith, L.; Seng, J.; Burris, H.; Rosen, P.; Hidalgo, M.; Ritch, P.; et al. Phase II trial of vatalanib in patients with advanced or metastatic pancreatic adenocarcinoma after first-line gemcitabine therapy (PCRT O4-001). Cancer Chemother. Pharmacol. 2014, 74, 379-387. [CrossRef]

53. Romero, A.H.; Sojo, F.; Arvelo, F.; Calderón, C.; Morales, A.; López, S.E. Anticancer potential of new 3-nitroaryl-6-(Nmethyl)piperazin-1,2,4-triazolo[3,4-a]phthalazines targeting voltage-gated K+ channel: Copper-catalyzed one-pot synthesis from 4-chloro-1-phthalazinyl-arylhydrazones. Bioorg. Chem. 2020, 101, 104031. [CrossRef]

54. Özden, S.; Atabey, D.; Yildiz, S.; Göker, H. Synthesis and potent antimicrobial activity of some novel methyl or ethyl 1Hbenzimidazole-5-carboxylates derivatives carrying amide or amidine groups. Bioorg. Med. Chem. 2005, 13, 1587-1597. [CrossRef]

55. Romero-Castro, A.; León-Rivera, I.; Ávila-Rojas, L.C.; Navarrete-Vázquez, G.; Nieto-Rodríguez, A. Synthesis and preliminary evaluation of selected 2-aryl-5(6)-nitro- 1H-benzimidazole derivatives as potential anticancer agents. Arch. Pharm. Res. 2011, 34, 181-189. [CrossRef]

56. Suk, F.M.; Liu, C.L.; Hsu, M.H.; Chuang, Y.T.; Wang, J.P.; Liao, Y.J. Treatment with a new benzimidazole derivative bearing a pyrrolidine side chain overcomes sorafenib resistance in hepatocellular carcinoma. Sci. Rep. 2019, 9, 17259. [CrossRef]

57. Bistrović, A.; Krstulović, L.; Harej, A.; Grbčić, P.; Sedić, M.; Koštrun, S.; Pavelić, S.K.; Bajić, M.; Raić-Malić, S. Design, synthesis and biological evaluation of novel benzimidazole amidines as potent multi-target inhibitors for the treatment of non-small cell lung cancer. Eur. J. Med. Chem. 2018, 143, 1616-1634. [CrossRef] [PubMed]

58. Sharma, P.; Larosa, C.; Antwi, J.; Govindarajan, R.; Werbovetz, K.A. Imidazoles as potential anticancer agents: An update on recent studies. Molecules 2021, 26, 4213. [CrossRef] [PubMed]

59. Kuang, W.B.; Huang, R.Z.; Fang, Y.L.; Liang, G.B.; Yang, C.H.; Ma, X.L.; Zhang, Y. Design, synthesis and pharmacological evaluation of novel 2-chloro-3-(1H-benzo[d]imidazol-2-yl)quinoline derivatives as antitumor agents: In vitro and in vivo antitumor activity, cell cycle arrest and apoptotic response. RSC Adv. 2018, 8, 24376-24385. [CrossRef]

60. Guzman, J.D. Natural cinnamic acids, synthetic derivatives and hybrids with antimicrobial activity. Molecules 2014, 19, 19292-19349. [CrossRef]

61. Donthiboina, K.; Anchi, P.; Gurram, S.; Sai Mani, G.; Lakshmi Uppu, J.; Godugu, C.; Shankaraiah, N.; Kamal, A. Synthesis and biological evaluation of substituted $\mathrm{N}-(2-(1 \mathrm{H}-$ benzo[d]imidazol-2-yl)phenyl)cinnamides as tubulin polymerization inhibitors. Bioorg. Chem. 2020, 103, 104191. [CrossRef] [PubMed]

62. Li, A.L.; Yang, Y.Q.; Wang, W.Y.; Liu, Q.S.; Sun, Y.; Gu, W. Synthesis, cytotoxicity and apoptosis-inducing activity of novel 1H-benzo[d]imidazole derivatives of dehydroabietic acid. J. Chin. Chem. Soc. 2020, 67, 1668-1678. [CrossRef]

63. Li, Y.; Tan, C.; Gao, C.; Zhang, C.; Luan, X.; Chen, X.; Liu, H.; Chen, Y.; Jiang, Y. Discovery of benzimidazole derivatives as novel multi-target EGFR, VEGFR-2 and PDGFR kinase inhibitors. Bioorg. Med. Chem. 2011, 19, 4529-4535. [CrossRef] [PubMed]

64. Li, L.; Quan, D.; Chen, J.; Ding, J.; Zhao, J.; Lv, L.; Chen, J. Design, synthesis, and biological evaluation of 1-substituted -2-aryl imidazoles targeting tubulin polymerization as potential anticancer agents. Eur. J. Med. Chem. 2019, 184, 111732. [CrossRef] [PubMed] 
65. Bai, Z.; Liu, X.; Guan, Q.; Ding, N.; Wei, Q.; Tong, B.; Zhao, M.; Zhang, W.; Ma, L. 5-(3,4,5-trimethoxybenzoyl)-4-methyl-2-(p-tolyl) imidazol (BZML) targets tubulin and DNA to induce anticancer activity and overcome multidrug resistance in colorectal cancer cells. Chem. Biol. Interact. 2020, 315, 108886. [CrossRef]

66. Zha, G.F.; Qin, H.L.; Youssif, B.G.M.; Amjad, M.W.; Raja, M.A.G.; Abdelazeem, A.H.; Bukhari, S.N.A. Discovery of potential anticancer multi-targeted ligustrazine based cyclohexanone and oxime analogs overcoming the cancer multidrug resistance. Eur. J. Med. Chem. 2017, 135, 34-48. [CrossRef] [PubMed]

67. Farag, A.K.; Hassan, A.H.E.; Sun Ahn, B.; Duk Park, K.; Joo Roh, E. Reprofiling of pyrimidine-based DAPK1/CSF1R dual inhibitors: Identification of 2,5-diamino-4-pyrimidinol derivatives as novel potential anticancer lead compounds. J. Enzym. Inhib. Med. Chem. 2020, 35, 311-324. [CrossRef]

68. Ning, C.Q.; Lu, C.; Hu, L.; Bi, Y.J.; Yao, L.; He, Y.J.; Liu, L.F.; Liu, X.Y.; Yu, N.F. Macrocyclic compounds as anti-cancer agents: Design and synthesis of multi-acting inhibitors against HDAC, FLT3 and JAK2. Eur. J. Med. Chem. 2015, 95, 104-115. [CrossRef]

69. Anonymous. Linifanib. Drugs $R$ D 2010, 10, 111-122. [CrossRef]

70. Shi, Z.H.; Liu, F.T.; Tian, H.Z.; Zhang, Y.M.; Li, N.G.; Lu, T. Design, synthesis and structure-activity relationship of diaryl-ureas with novel isoxazol[3,4-b]pyridine-3-amino-structure as multi-target inhibitors against receptor tyrosine kinase. Bioorg. Med. Chem. 2018, 26, 4735-4744. [CrossRef]

71. Wang, J.; Zhang, L.; Pan, X.; Dai, B.; Sun, Y.; Li, C.; Zhang, J. Discovery of multi-target receptor tyrosine kinase inhibitors as novel anti-angiogenesis agents. Sci. Rep. 2017, 7, 1-11. [CrossRef]

72. Dias, D.A.; Urban, S.; Roessner, U. A Historical Overview of Natural Products in Drug Discovery. Metabolites 2012, 2, 303-336. [CrossRef] [PubMed]

73. Yuan, H.; Ma, Q.; Ye, L.; Piao, G. The Traditional Medicine and Modern Medicine from Natural Products. Molecules 2016, $21,559$. [CrossRef] [PubMed]

74. Sakyi, P.O.; Amewu, R.K.; Devine, R.N.O.A.; Ismaila, E.; Miller, W.A.; Kwofie, S.K. The Search for Putative Hits in Combating Leishmaniasis: The Contributions of Natural Products Over the Last Decade. Nat. Prod. Bioprospect. 2021, 11, 489-544. [CrossRef]

75. Patridge, E.; Gareiss, P.; Kinch, M.S.; Hoyer, D. An analysis of FDA-approved drugs: Natural products and their derivatives. Drug Discov. Today 2016, 21, 204-207. [CrossRef]

76. Perdue, R.E.; Hartwel, J.L. Proceedings of the 16th Annual Meeting of the Society for Economic Botany-Plants and cancer. Cancer Treat. Rep. 1976, 60, 973-1214.

77. Newman, D.J.; Cragg, G.M.; Snader, K.M. Natural Products as Sources of New Drugs over the Period 1981-2002. J. Nat. Prod. 2003, 66, 1022-1037. [CrossRef]

78. Li-Weber, M. New therapeutic aspects of flavones: The anticancer properties of Scutellaria and its main active constituents Wogonin, Baicalein and Baicalin. Cancer Treat. Rev. 2009, 35, 57-68. [CrossRef]

79. Wen, C.; Wu, L.; Fu, L.; Zhang, X.; Zhou, H. Berberine enhances the anti-tumor activity of tamoxifen in drug-sensitive MCF-7 and drug-resistant MCF-7/TAM cells. Mol. Med. Rep. 2016, 14, 2250-2256. [CrossRef] [PubMed]

80. Puthdee, N.; Seubwai, W.; Vaeteewoottacharn, K.; Boonmars, T.; Cha'on, U.; Phoomak, C.; Wongkham, S. Berberine induces cell cycle arrest in cholangiocarcinoma cell lines via inhibition of NF-kB and STAT3 pathways. Biol. Pharm. Bull. 2017, 40, 751-757. [CrossRef]

81. Lin, C.C.; Kao, S.T.; Chen, G.W.; Chung, J.G. Berberine decreased N-acetylation of 2-aminofluorene through inhibition of $\mathrm{N}$-acetyltransferase gene expression in human leukemia HL-60 cells. Anticancer Res. 2005, 25, 4149-4155.

82. Jia, J.; Kang, X.; Liu, Y.; Zhang, J. Inhibition of human liver cancer cell growth by evodiamine involves apoptosis and deactivation of PI3K/AKT pathway. Appl. Biol. Chem. 2020, 63, 67. [CrossRef]

83. Li, X.; Wu, S.; Dong, G.; Chen, S.; Ma, Z.; Liu, D.; Sheng, C. Natural Product Evodiamine with Borate Trigger Unit: Discovery of Potent Antitumor Agents against Colon Cancer. ACS Med. Chem. Lett. 2020, 11, 439-444. [CrossRef] [PubMed]

84. Song, X.; Qi, X.; Wang, Q.; Zhu, W.; Li, J. A novel multi-target inhibitor harboring selectivity of inhibiting EGFR T790M sparing wild-type EGFR. Am. J. Cancer Res. 2017, 7, 1884-1898.

85. Bishayee, K.; Chakraborty, D.; Ghosh, S.; Boujedaini, N.; Khuda-Bukhsh, A.R. Lycopodine triggers apoptosis by modulating 5-lipoxygenase, and depolarizing mitochondrial membrane potential in androgen sensitive and refractory prostate cancer cells without modulating p53 activity: Signaling cascade and drug-DNA interaction. Eur. J. Pharmacol. 2013, 698, 110-121. [CrossRef]

86. Robles, A.J.; Du, L.; Cichewicz, R.H.; Mooberry, S.L. Maximiscin Induces DNA Damage, Activates DNA Damage Response Pathways, and Has Selective Cytotoxic Activity against a Subtype of Triple-Negative Breast Cancer. J. Nat. Prod. 2016, 79, $1822-1827$. [CrossRef] [PubMed]

87. Crampton, S.L.; Adams, E.G.; Kuentzel, S.L.; Li, L.H.; Badiner, G.; Bhuyan1, B.K. Biochemical and Cellular Effects of Didemnins A and B. Cancer Res. 1984, 44, 1796-1801.

88. Chun, H.G.; Davies, B.; Hoth, D.; Suffness, M.; Plowman, J.; Flora, K.; Grieshaber, C.; Leyland-Jones, B. Didemnin B-The first marine compound entering clinical trials as an antineoplastic agent. Investig. New Drugs 1986, 4, 279-284.

89. Ahuja, D.; Vera, M.D.; SirDeshpande, B.V.; Morimoto, H.; Williams, P.G.; Joullié, M.M.; Toogood, P.L. Inhibition of protein synthesis by didemnin B: How EF-1 $\alpha$ mediates inhibition of translocation. Biochemistry 2000, 39, 4339-4346. [CrossRef]

90. Li, L.H.; Timmins, L.G.; Wallace, T.L.; Krueger, W.C.; Prairie, M.D.; Im, W.B. Mechanism of Action of Didemnin B, a Depsipeptide from the Sea. Cancer Lett. 1984, 23, 279-288. [CrossRef] 
91. Palumbo, A.; Castellano, I.; Napolitano, A. Ovothiol: A Potent Natural Antioxidant from Marine Organisms. Blue Biotechnol. 2018, 2, 583-610.

92. Russo, G.L.; Russo, M.; Castellano, I.; Napolitano, A.; Palumbo, A. Ovothiol isolated from sea urchin oocytes induces autophagy in the Hep-G2 cell line. Mar. Drugs 2014, 12, 4069-4085. [CrossRef] [PubMed]

93. Bewley, C.A.; Detritus, C.; Faulkner, D.J. Microsclerodermins A and B. Antifungal Cyclic Peptides from the Lithistid Sponge Microscleroderma sp. J. Am. Chem. Soc. 1994, 116, 7631-7636. [CrossRef]

94. Guzmán, E.A.; Maers, K.; Roberts, J.; Kemami-Wangun, H.V.; Harmody, D.; Wright, A.E. The marine natural product microsclerodermin A is a novel inhibitor of the nuclear factor kappa B and induces apoptosis in pancreatic cancer cells. Investig. New Drugs 2015, 33, 86-94. [CrossRef] [PubMed]

95. Chabowska, G.; Barg, E.; Wójcicka, A. Biological activity of naturally derived naphthyridines. Molecules 2021, 26, 4324. [CrossRef] [PubMed]

96. Dyshlovoy, S.A.; Fedorov, S.N.; Shubina, L.K.; Kuzmich, A.S.; Bokemeyer, C.; Keller-Von Amsberg, G.; Honecker, F. Aaptamines from the marine sponge Aaptos sp. display anticancer activities in human cancer cell lines and modulate AP-1-, NF- B-, and p53-dependent transcriptional activity in mouse JB6 Cl41 cells. Biomed. Res. Int. 2014, 2014, 469309. [CrossRef]

97. Kim, K.S.; Cui, X.; Lee, D.S.; Sohn, J.H.; Yim, J.H.; Kim, Y.C.; Oh, H. Anti-Inflammatory Effect of Neoechinulin A from the Marine Fungus Eurotium sp. SF-5989 through the Suppression of NF-kB and p38 MAPK Pathways in Lipopolysaccharide-Stimulated RAW264.7 Macrophages. Molecules 2013, 18, 13245-13259. [CrossRef]

98. Wijesekara, I.; Li, Y.X.; Vo, T.S.; Van Ta, Q.; Ngo, D.H.; Kim, S.K. Induction of apoptosis in human cervical carcinoma HeLa cells by neoechinulin A from marine-derived fungus Microsporum sp. Process. Biochem. 2013, 48, 68-72. [CrossRef]

99. Zhang, Q.; Chen, W.; Lv, X.; Weng, Q.; Chen, M.; Cui, R.; Liang, G.; Ji, J. Piperlongumine, a novel TrxR1 inhibitor, induces apoptosis in hepatocellular carcinoma cells by ROS-mediated ER stress. Front. Pharmacol. 2019, 10, 1180. [CrossRef]

100. Rawat, L.; Hegde, H.; Hoti, S.L.; Nayak, V. Piperlongumine Induces ROS Mediated Cell Death and Synergizes Paclitaxel in Human Intestinal Cancer Cells. Biomed. Pharmacother. 2020, 128, 110243. [CrossRef]

101. Yamaguchi, Y.; Kasukabe, T.; Kumakura, S. Piperlongumine rapidly induces the death of human pancreatic cancer cells mainly through the induction of ferroptosis. Int. J. Oncol. 2018, 52, 1011-1022. [CrossRef]

102. Han, N.; Yang, Z.; Liu, Z.; Liu, H.; Yin, J. Research progress on natural benzophenanthridine alkaloids and their pharmacological functions: A review. Nat. Prod. Commun. 2016, 11, 1181-1188. [CrossRef] [PubMed]

103. Xu, J.Y.; Meng, Q.H.; Chong, Y.; Jiao, Y.; Zhao, L.; Rosen, E.M.; Fan, S. Sanguinarine inhibits growth of human cervical cancer cells through the induction of apoptosis. Oncol. Rep. 2012, 28, 2264-2270. [CrossRef] [PubMed]

104. Adhami, V.M.; Aziz, M.H.; Reagan-Shaw, S.R.; Nihal, M.; Mukhtar, H.; Ahmad, N. Sanguinarine causes cell cyle blockade and apoptosis of human prostate carcinoma cells via modulation of cylin kinase inhibitor-cyclin-cyclin-dependent kinase machinery. Mol. Cancer Ther. 2004, 3, 933-940.

105. Available online: https://www.ebi.ac.uk/chebi/searchId.do?chebiId=CHEBI:78373 (accessed on 1 September 2021).

106. Yang, B.; Zhang, D.; Qian, J.; Cheng, Y. Chelerythrine suppresses proliferation and metastasis of human prostate cancer cells via modulating MMP/TIMP/NF-kB system. Mol. Cell. Biochem. 2020, 474, 199-208. [CrossRef]

107. Chen, X.M.; Zhang, M.; Fan, P.L.; Qin, Y.H.; Zhao, H.W. Chelerythrine chloride induces apoptosis in renal cancer HEK-293 and SW-839 cell lines. Oncol. Lett. 2016, 11, 3917-3924. [CrossRef] [PubMed]

108. Arthur, H.R.; Hui, W.H.; Ng, Y.L. An examination of the rutaceae of Hong Kong. Part II. The alkaloids, nitidine and oxynitidine, from Zanthoxylum nitidum. J. Chem. Soc. 1959, 1840-1845. [CrossRef]

109. Torto, F.G.; Mensah, I.A. Alkaloids of Fagara macrophylla. Phytochemistry 1970, 9, 911-914. [CrossRef]

110. Wani, M.C.; Taylor, H.L.; Wall, M.E.; Coggon, P.; Mcphail, A.T. Plant Antitumor Agents. VI. The Isolation and Structure of Taxol, a Novel Antileukemic and Antitumor Agent from Taxus brevifolia. J. Am. Chem. Soc. 1971, 93, 2325-2327. [CrossRef]

111. Wall, M.E.; Wani, M.C.; Taylor, H. Plant antitumor agents, 27. Isolation, structure, and structure activity relationships of alkaloids from Fagara macrophylla. J. Nat. Prod. 1987, 50, 1095-1099. [CrossRef]

112. Fish, F.; Waterman, P.G. Methanol-soluble quaternary alkaloids from African Fagara species. Phytochemistry 1972, 11, 3007-3014. [CrossRef]

113. Bouquet, J.; Rivaud, M.; Chevalley, S.; Deharo, E.; Jullian, V.; Valentin, A. Biological activities of nitidine, a potential anti-malarial lead compound. Malar. J. 2012, 11, 67. [CrossRef] [PubMed]

114. Gakunju, D.M.N.; Mberu, E.K.; Dossaji, S.F.; Gray, A.I.; Waigh, R.D.; Waterman, P.G.; Watkins, W.M. Potent antimalarial activity of the alkaloid nitidine, isolated from a Kenyan herbal remedy. Antimicrob. Agents Chemother. 1995, 39, 2606-2609. [CrossRef] [PubMed]

115. Addae-Mensah, I.; Munenge, R.; Guantai, A.N. Comparative examination of two Zanthoxylum benzophenanthridine alkaloids for effects in rabbits. Phytother. Res. 1989, 3, 165-169. [CrossRef]

116. Wang, L.K.; Hecht, S.M.; Johnson, R.K. Inhibition of Topoisomerase I Function by Nitidine and Fagaronine. Chem. Res. Toxicol. 1993, 6, 813-818. [CrossRef]

117. Nyangulu, J.M.; Hargreaves, S.L.; Sharples, S.L.; Mackay, S.P.; Waigh, R.D.; Duval, O.; Mberu, E.K.; Watkins, W.M. Antimalarial benzo[c]phenanthridines. Bioorg. Med. Chem. Lett. 2005, 15, 2007-2010. [CrossRef]

118. Pan, X.; Han, H.; Wang, L.; Yang, L.; Li, R.; Li, Z.; Liu, J.; Zhao, Q.; Qian, M.; Liu, M.; et al. Nitidine Chloride inhibits breast cancer cells migration and invasion by suppressing c-Src/FAK associated signaling pathway. Cancer Lett. 2011, 313, 181-191. [CrossRef] 
119. Liao, J.; Xu, T.; Zheng, J.X.; Lin, J.M.; Cai, Q.Y.; Yu, D.B.; Peng, J. Nitidine chloride inhibits hepatocellular carcinoma cell growth in vivo through the suppression of the JAK1/STAT3 signaling pathway. Int. J. Mol. Med. 2013, 32, 79-84. [CrossRef]

120. Bi, J.R.; Zheng, Y.; Fang, L.Q.; Guan, Y.C.; Ma, A.Q.; Wu, J. Nano-Sized MIL-100(Fe) as a Carrier Material for Nitidine Chloride Reduces Toxicity and Enhances Anticancer Effects In Vitro. J. Inorg. Organomet. Polym. Mater. 2020, 30, 3388-3395. [CrossRef]

121. Available online: https://www.wahooas.org/web-ooas/sites/default/files/publications/2185/west-african-herbal-pharmacopoeiaok.pdf (accessed on 1 October 2021).

122. Dewick, P.M. Tumor inhibitors from plants. Trease Evans' Pharmacogn. 1996, 14, 210-214. [CrossRef]

123. Messmer, W.M.; Tin-wa, M.; Fong, H.H.S.; Bevelle, C.; Farnsworth, N.R.; Abraham, D.J.; Trojánek, J. Fagaronine, a new tumor inhibitor isolated from Fagara zanthoxyloides lam. (rutaceae). J. Pharm. Sci. 1972, 61, 1858-1859. [CrossRef]

124. Barret, Y.; Sauvaire, Y. Fagaronine, a novel antileukaemic alkaloid. Phytother. Res. 1992, 6, 59-63. [CrossRef]

125. Larsen, A.K.; Grondard, L.; Couprie, J.; Desoize, B.; Comoe, L.; Jardillier, J.C.; Riou, J.F. The antileukemic alkaloid fagaronine is an inhibitor of DNA topoisomerases I and II. Biochem. Pharmacol. 1993, 46, 1403-1412. [CrossRef]

126. Torto, F.G.; Mensah, I.A.; Baxter, I. Fagaridine: A phenolic benzophenanthridine alkaloid from Fagara xanthoxyloides. Phytochemistry 1973, 12, 2315-2317. [CrossRef]

127. Topcu, Z. DNA topoisomerases as targets for anticancer drugs. J. Clin. Pharm. Ther. 2001, 26, 405-416. [CrossRef]

128. Pathania, S.; Narang, R.K.; Rawal, R.K. Role of sulphur-heterocycles in medicinal chemistry: An update. Eur. J. Med. Chem. 2019, 180, 486-508. [CrossRef]

129. Kupfahl, C.; Michalka, A.; Lass-Flo, C.; Fischer, G.; Haase, G.; Ruppert, T.; Geginat, G.; Hof, H. Gliotoxin production by clinical and environmental Aspergillus fumigatus strains. Int. J. Med. Microbiol. 2008, 298, 319-327. [CrossRef]

130. Katz, R. United States. Eur. J. Polit. Res. Polit. Data Yearb. 2015, 54, 309-315. [CrossRef]

131. Nguyen, V.T.; Lee, J.S.; Qian, Z.J.; Li, Y.X.; Kim, K.N.; Heo, S.J.; Jeon, Y.J.; Park, W.S.; Choi, I.W.; Je, J.Y.; et al. Gliotoxin isolated from marine fungus Aspergillus sp. induces apoptosis of human cervical cancer and chondrosarcoma cells. Mar. Drugs 2014, 12, 69-87. [CrossRef]

132. Chen, J.; Wang, C.; Lan, W.; Huang, C.; Lin, M.; Wang, Z.; Liang, W.; Iwamoto, A.; Yang, X.; Liu, H.; et al. Gliotoxin inhibits proliferation and induces apoptosis in colorectal cancer cells. Mar. Drugs 2015, 13, 6259-6273. [CrossRef]

133. Abdelazeem, A.H.; El-Saadi, M.T.; Said, E.G.; Youssif, B.G.M.; Omar, H.A.; El-Moghazy, S.M. Novel diphenylthiazole derivatives with multi-target mechanism: Synthesis, docking study, anticancer and anti-inflammatory activities. Bioorg. Chem. 2017, 75, 127-138. [CrossRef]

134. Stiborová, M.; Poljaková, J.; Martínková, E.; Bořek-Dohalská, L.; Eckschlager, T.; Kizek, R.; Frei, E. Ellipticine cytotoxicity to cancer cell lines-A comparative study. Interdiscip. Toxicol. 2011, 4, 98-105. [CrossRef]

135. Ceramella, J.; Caruso, A.; Occhiuzzi, M.A.; Iacopetta, D.; Barbarossa, A.; Rizzuti, B.; Dallemagne, P.; Rault, S.; El-Kashef, H.; Saturnino, C.; et al. Benzothienoquinazolinones as new multi-target scaffolds: Dual inhibition of human Topoisomerase I and tubulin polymerization. Eur. J. Med. Chem. 2019, 181, 111583. [CrossRef]

136. Aly, A.A.; Bräse, S.; Hassan, A.A.; Mohamed, N.K.; El-Haleem, L.E.A.; Nieger, M.; Morsy, N.M.; Alshammari, M.B.; Ibrahim, M.A.A.; Abdelhafez, E.M.N. Design, Synthesis, and Molecular Docking of Paracyclophanyl-Thiazole Hybrids as Novel CDK1 Inhibitors and Apoptosis Inducing Anti-Melanoma Agents. Molecules 2020, 25, 5569. [CrossRef] [PubMed]

137. Megally Abdo, N.Y.; Milad Mohareb, R.; Halim, P.A. Uses of cyclohexane-1,3-dione for the synthesis of 1,2,4-triazine derivatives as anti-proliferative agents and tyrosine kinases inhibitors. Bioorg. Chem. 2020, 97, 103667. [CrossRef] [PubMed]

138. Pardhasaradhi, B.V.V.; Reddy, M.; Ali, A.M.; Kumari, A.L.; Khar, A. Differential cytotoxic effects of Annona squamosa seed extracts on human tumour cell lines: Role of reactive oxygen species and glutathione. J. Biosci. 2005, 30, 237-244. [CrossRef] [PubMed]

139. Ma, C.; Wang, Q.; Shi, Y.; Li, Y.; Wang, X.; Li, X.; Chen, Y.; Chen, J. Three new antitumor annonaceous acetogenins from the seeds of Annona squamosa. Nat. Prod. Res. 2017, 31, 2085-2090. [CrossRef]

140. Youn, U.J.; Miklossy, G.; Chai, X.; Wongwiwatthananukit, S.; Toyama, O.; Songsak, T.; Turkson, J.; Chang, L.C. Bioactive sesquiterpene lactones and other compounds isolated from Vernonia cinerea. Fitoterapia 2014, 93, 194-200. [CrossRef]

141. Youn, U.J.; Park, E.J.; Kondratyuk, T.P.; Simmons, C.J.; Borris, R.P.; Tanamatayarat, P.; Wongwiwatthananukit, S.; Toyama, O.; Songsak, T.; Pezzuto, J.M.; et al. Anti-inflammatory sesquiterpene lactones from the flower of Vernonia cinerea. Bioorg. Med. Chem. Lett. 2012, 22, 5559-5562. [CrossRef]

142. Jung, H.J.; Kim, Y.; Shin, J.Y.; Sohng, J.K.; Kwon, H.J. Antiangiogenic activity of herboxidiene via downregulation of vascular endothelial growth factor receptor-2 and hypoxia-inducible factor-1 $\alpha$. Arch. Pharm. Res. 2015, 38, 1728-1735. [CrossRef]

143. Liu, Q.M.; Zhao, H.Y.; Zhong, X.K.; Jiang, J.G. Eclipta prostrata L. phytochemicals: Isolation, structure elucidation, and their antitumor activity. Food Chem. Toxicol. 2012, 50, 4016-4022. [CrossRef]

144. Sarveswaran, S.; Gautam, S.C.; Ghosh, J. Wedelolactone, a medicinal plant-derived coumestan, induces caspase-dependent apoptosis in prostate cancer cells via downregulation of PKC $\varepsilon$ without inhibiting Akt. Int. J. Oncol. 2012, 41, 2191-2199. [CrossRef] [PubMed]

145. Cho, Y.J.; Woo, J.H.; Lee, J.S.; Jang, D.S.; Lee, K.T.; Choi, J.H. Eclalbasaponin II induces autophagic and apoptotic cell death in human ovarian cancer cells. J. Pharmacol. Sci. 2016, 132, 6-14. [CrossRef] [PubMed]

146. Lin, Y.; Shi, R.; Wang, X.; Shen, H.-M. Luteolin, a Flavonoid with Potential for Cancer Prevention and Therapy. Curr. Cancer Drug Targets 2008, 8, 634-646. [CrossRef] [PubMed] 
147. Hwang, Y.J.; Lee, E.J.; Kim, H.R.; Hwang, K.A. Molecular mechanisms of luteolin-7-o-glucoside-induced growth inhibition on human liver cancer cells: G2/m cell cycle arrest and caspase-independent apoptotic signaling pathways. BMB Rep. 2013, 46, 611-616. [CrossRef]

148. Jiang, D.; Rasul, A.; Batool, R.; Sarfraz, I.; Hussain, G.; Mateen Tahir, M.; Qin, T.; Selamoglu, Z.; Ali, M.; Li, J.; et al. Potential Anticancer Properties and Mechanisms of Action of Formononetin. Biomed. Res. Int. 2019, 2019, 5854315. [CrossRef]

149. García, V.; Lara-Chica, M.; Cantarero, I.; Sterner, O.; Calzado, M.A.; Muñoz, E. Galiellalactone induces cell cycle arrest and apoptosis through the ATM/ATR pathway in prostate cancer cells. Oncotarget 2016, 7, 4490-4506. [CrossRef]

150. Don-Doncow, N.; Escobar, Z.; Johansson, M.; Kjellström, S.; Garcia, V.; Munoz, E.; Sterner, O.; Bjartell, A.; Hellsten, R. Galiellalactone is a direct inhibitor of the transcription factor STAT3 in prostate cancer cells. J. Biol. Chem. 2014, 289, 15969-15978. [CrossRef]

151. Bury, M.; Girault, A.; Megalizzi, V.; Spiegl-Kreinecker, S.; Mathieu, V.; Berger, W.; Evidente, A.; Kornienko, A.; Gailly, P.; Vandier, C.; et al. Ophiobolin A induces paraptosis-like cell death in human glioblastoma cells by decreasing BKCa channel activity. Cell Death Dis. 2013, 4, e561. [CrossRef]

152. Mohyeldin, M.M.; Akl, M.R.; Siddique, A.B.; Hassan, H.M.; El Sayed, K.A. The marine-derived pachycladin diterpenoids as novel inhibitors of wild-type and mutant EGFR. Biochem. Pharmacol. 2017, 126, 51-68. [CrossRef]

153. Seo, Y.J.; Lee, K.T.; Rho, J.R.; Choi, J.H. Phorbaketal A, isolated from the marine sponge Phorbas sp., exerts its anti-inflammatory effects via NF-кB inhibition and heme oxygenase-1 activation in lipopolysaccharide-stimulated macrophages. Mar. Drugs 2015, 13, 7005-7019. [CrossRef]

154. Rho, J.R.; Hwang, B.S.; Sim, C.J.; Joung, S.; Lee, H.Y.; Kim, H.J. Phorbaketals A, B, and C, sesterterpenoids with a spiroketal of hydrobenzopyran moiety isolated from the marine sponge Phorbas sp. Org. Lett. 2009, 11, 5590-5593. [CrossRef]

155. Chen, H.; Zhang, X.; Feng, Y.; Rui, W.; Shi, Z.; Wu, L. Bioactive components of Glycyrrhiza uralensis mediate drug functions and properties through regulation of CYP450 enzymes. Mol. Med. Rep. 2014, 10, 1355-1362. [CrossRef] [PubMed]

156. Zhang, S.P.; Zhou, Y.J.; Liu, Y.; Cai, Y. qing Effect of liquiritigenin, a flavanone existed from Radix glycyrrhizae on pro-apoptotic in SMMC-7721 cells. Food Chem. Toxicol. 2009, 47, 693-701. [CrossRef] [PubMed]

157. Liu, Y.; Xie, S.; Wang, Y.; Luo, K.; Wang, Y.; Cai, Y. Liquiritigenin inhibits tumor growth and vascularization in a mouse model of HeLa cells. Molecules 2012, 17, 7206-7216. [CrossRef] [PubMed]

158. Ayeka, P.A.; Bian, Y.; Mwitari, P.G.; Chu, X.; Zhang, Y.; Uzayisenga, R.; Otachi, E.O. Immunomodulatory and anticancer potential of Gan cao (Glycyrrhiza uralensis Fisch.) polysaccharides by CT-26 colon carcinoma cell growth inhibition and cytokine IL-7 upregulation in vitro. BMC Complement. Altern. Med. 2016, 16, 206. [CrossRef] [PubMed]

159. Ayeka, P.A.; Bian, Y.H.; Githaiga, P.M.; Zhao, Y. The immunomodulatory activities of licorice polysaccharides (Glycyrrhiza uralensis Fisch.) in CT 26 tumor-bearing mice. BMC Complement. Altern. Med. 2017, 17, 536. [CrossRef] [PubMed]

160. Thiugnanam, S.; Xu, L.; Ramaswamy, K.; Gnanasekar, M. Glycyrrhizin induces apoptosis in prostate cancer cell lines DU-145 and LNCaP. Oncol. Rep. 2008, 20, 1387-1392. [CrossRef]

161. Chueh, F.S.; Hsiao, Y.T.; Chang, S.J.; Wu, P.P.; Yang, J.S.; Lin, J.J.; Chung, J.G.; Lai, T.Y. Glycyrrhizic acid induces apoptosis in WEHI-3 mouse leukemia cells through the caspase- and mitochondria-dependent pathways. Oncol. Rep. 2012, 28, 2069-2076. [CrossRef]

162. Huang, R.Y.; Chu, Y.L.; Jiang, Z.B.; Chen, X.M.; Zhang, X.; Zeng, X. Glycyrrhizin suppresses lung adenocarcinoma cell growth through inhibition of thromboxane synthase. Cell. Physiol. Biochem. 2014, 33, 375-388. [CrossRef]

163. Niwa, K.; Lian, Z.; Onogi, K.; Yun, W.U.; Tang, L.; Mori, H.; Tamaya, T. Preventive effects of glycyrrhizin on estrogen-related endometrial carcinogenesis in mice. Oncol. Rep. 2007, 17, 617-622. [CrossRef]

164. Cathcart, M.C.; Reynolds, J.V.; O’Byrne, K.J.; Pidgeon, G.P. The role of prostacyclin synthase and thromboxane synthase signaling in the development and progression of cancer. Biochim. Biophys. Acta Rev. Cancer 2010, 1805, 153-166. [CrossRef] [PubMed]

165. Kim, Y.W.; Kang, H.E.; Lee, M.G.; Hwang, S.J.; Kim, S.C.; Lee, C.H.; Kim, S.G. Liquiritigenin, a flavonoid aglycone from licorice, has a choleretic effect and the ability to induce hepatic transporters and phase-II enzymes. Am. J. Physiol. Gastrointest. Liver Physiol. 2009, 296, 372-381. [CrossRef] [PubMed]

166. Mersereau, J.E.; Levy, N.; Staub, R.E.; Baggett, S.; Zogric, T.; Chow, S.; Ricke, W.A.; Tagliaferri, M.; Cohen, I.; Bjeldanes, L.F.; et al. Liquiritigenin is a plant-derived highly selective estrogen receptor agonist. Mol. Cell. Endocrinol. 2008, 283, 49-57. [CrossRef]

167. Green, S.E. In vitro Comparison of Estrogenic Activities of Popular Women's Health Botanicals. Ph.D. Thesis, University of Illinois Chicago, Chicago, IL, USA, 2015.

168. Liu, C.; Wang, Y.; Xie, S.; Zhou, Y.; Ren, X.; Li, X.; Cai, Y. Liquiritigenin induces mitochondria-mediated apoptosis via cytochrome c release and caspases activation in heLa cells. Phytother. Res. 2011, 25, 277-283. [CrossRef] [PubMed]

169. Huang, W.; Tang, S.; Qiao, X.; Ma, W.; Ji, S.; Wang, K.; Ye, M.; Yu, S. Isoangustone A induces apoptosis in SW480 human colorectal adenocarcinoma cells by disrupting mitochondrial functions. Fitoterapia 2014, 94, 36-47. [CrossRef]

170. Tang, S.; Cai, S.; Ji, S.; Yan, X.; Zhang, W.; Qiao, X.; Zhang, H.; Ye, M.; Yu, S. Isoangustone A Induces Autophagic Cell Death in Colorectal Cancer Cells by Activating AMPK Signaling. Fitoterapia 2021, 152, 104935. [CrossRef]

171. Song, N.R.; Lee, E.; Byun, S.; Kim, J.E.; Mottamal, M.; Park, J.H.Y.; Lim, S.S.; Bode, A.M.; Lee, H.J.; Lee, K.W.; et al. Isoangustone A, a novel licorice compound, inhibits cell proliferation by targeting PI3K, MKK4, and MKK7 in human melanoma. Cancer Prev. Res. 2013, 6, 1293-1303. [CrossRef] 
172. Seon, M.R.; Lim, S.S.; Choi, H.J.; Park, S.Y.; Cho, H.J.; Kim, J.K.; Kim, J.; Kwon, D.Y.; Park, J.H.Y. Isoangustone a present in hexane/ethanol extract of Glycyrrhiza uralensis induces apoptosis in DU145 human prostate cancer cells via the activation of DR4 and intrinsic apoptosis pathway. Mol. Nutr. Food Res. 2010, 54, 1329-1339. [CrossRef]

173. Fraunfelder, F.T. Herbal medicine and dietary supplement induced ocular side effects. Clin. Ocul. Toxicol. 2008, 307-313. [CrossRef]

174. Hsu, Y.L.; Wu, L.Y.; Hou, M.F.; Tsai, E.M.; Lee, J.N.; Liang, H.L.; Jong, Y.J.; Hung, C.H.; Kuo, P.L. Glabridin, an isoflavan from licorice root, inhibits migration, invasion and angiogenesis of MDA-MB-231 human breast adenocarcinoma cells by inhibiting focal adhesion kinase/Rho signaling pathway. Mol. Nutr. Food Res. 2011, 55, 318-327. [CrossRef]

175. Kim, A.; Ma, J.Y. Isoliquiritin Apioside Suppresses in vitro Invasiveness and Angiogenesis of Cancer Cells and Endothelial Cells. Front. Pharmacol. 2018, 9, 1455. [CrossRef] [PubMed]

176. Kong, L.D.; Zhang, Y.; Pa, X.; Tan, R.X.; Cheng, C.H. Inhibition of xanthine oxidase by liquiritigenin and isoliquiritigenin isolated from Sinofranchetia chinensis. Cell. Mol. Life Sci. 2000, 57, 500-505. [CrossRef]

177. Ji, S.; Tang, S.; Li, K.; Li, Z.; Liang, W.; Qiao, X.; Wang, Q.; Yu, S.; Ye, M. Licoricidin inhibits the growth of SW480 human colorectal adenocarcinoma cells in vitro and in vivo by inducing cycle arrest, apoptosis and autophagy. Toxicol. Appl. Pharmacol. 2017, 326, 25-33. [CrossRef]

178. Park, S.Y.; Kwon, S.J.; Lim, S.S.; Kim, J.K.; Lee, K.W.; Park, J.H.Y. Licoricidin, an active compound in the hexane/ethanol extract of Glycyrrhiza uralensis, inhibits lung metastasis of 4 T1 murine mammary carcinoma cells. Int. J. Mol. Sci. 2016, 17, 934. [CrossRef] [PubMed]

179. Wang, Y.; Wang, S.; Liu, J.; Lu, Y.; Li, D. Licoricidin enhances gemcitabine-induced cytotoxicity in osteosarcoma cells by suppressing the Akt and NF-kB signal pathways. Chem. Biol. Interact. 2018, 290, 44-51. [CrossRef] [PubMed]

180. Kim, K.J.; Xuan, S.H.; Park, S.N. Licoricidin, an isoflavonoid isolated from Glycyrrhiza uralensis Fisher, prevents UVA-induced photoaging of human dermal fibroblasts. Int. J. Cosmet. Sci. 2017, 39, 133-140. [CrossRef]

181. Shin, E.M.; Kim, S.; Merfort, I.; Kim, Y.S. Glycyrol induces apoptosis in human Jurkat T cell lymphocytes via the Fas-FasL/caspase8 pathway. Planta Med. 2011, 77, 242-247. [CrossRef]

182. Sharma, V.; Katiyar, A.; Agrawal, R.C.; Sharma, V.; Katiyar, A. Glycyrrhiza Glabra: Chemistry and Pharmacological Activity 4. Springer Int. Publ. AG 2018, 4, 87-100. [CrossRef]

183. Zhao, C.; Wang, D.; Gao, Z.; Kan, H.; Qiu, F.; Chen, L.; Li, H. Licocoumarone induces BxPC-3 pancreatic adenocarcinoma cell death by inhibiting DYRK1A. Chem. Biol. Interact. 2020, 316, 108913. [CrossRef]

184. Watanabe, M.; Hayakawa, S.; Isemura, M.; Kumazawa, S.; Nakayama, T.; Mori, C.; Kawakami, T. Identification of licocoumarone as an apoptosis-inducing component in licorice. Biol. Pharm. Bull. 2002, 25, 1388-1390. [CrossRef]

185. Ardalani, H.; Avan, A.; Ghayour-Mobarhan, M. Podophyllotoxin: A novel potential natural anticancer agent. Avicenna J. Phytomed. 2017, 7, 285. [PubMed]

186. Wei, J.; Chen, J.; Ju, P.; Ma, L.; Chen, L.; Ma, W.; Zheng, T.; Yang, G.; Wang, Y.X. Synthesis and biological evaluation of 4 $\beta$-n-acetylamino substituted podophyllotoxin derivatives as novel anticancer agents. Front. Chem. 2019, 7, 253. [CrossRef] [PubMed]

187. Khaled, M.; Belaaloui, G.; Jiang, Z.Z.; Zhu, X.; Zhang, L.Y. Antitumor effect of Deoxypodophyllotoxin on human breast cancer xenograft transplanted in BALB/c nude mice model. J. Infect. Chemother. 2016, 22, 692-696. [CrossRef]

188. Joubouhi, C.; Mabou, F.D.; Foning Tebou, P.L.; Ngnokam, D.; Harakat, D.; Voutquenne-Nazabadioko, L. Five new iridoïd dimers from the fruits of Canthium subcordatum DC (syn. Psydrax subcordata DC). Phytochem. Lett. 2015, 13, 348-354. [CrossRef]

189. Hussain, H.; Nazir, M.; Green, I.R.; Saleem, M.; Raza, M.L. Therapeutic potential of iridoid derivatives: Patent review. Inventions 2019, 4, 29. [CrossRef]

190. Essien, E.E.; Newby, J.S.; Walker, T.M.; Setzer, W.N.; Ekundayo, O. Characterization and Antimicrobial Activity of Volatile Constituents from Fresh Fruits of Alchornea cordifolia and Canthium subcordatum. Medicines 2016, 3, 1. [CrossRef]

191. Hirata, T.; Ikeda, T.; Fujikawa, T.; Nishibe, S. The chemistry and bioactivity of eucommia ulmoides oliver leaves. Stud. Nat. Prod. Chem. 2014, 41, 225-260. [CrossRef]

192. Kim, B.C.; Kim, H.G.; Lee, S.A.; Lim, S.; Park, E.H.; Kim, S.J.; Lim, C.J. Genipin-induced apoptosis in hepatoma cells is mediated by reactive oxygen species/c-Jun NH2-terminal kinase-dependent activation of mitochondrial pathway. Biochem. Pharmacol. 2005, 70, 1398-1407. [CrossRef]

193. Ko, H.; Kim, J.M.; Kim, S.J.; Shim, S.H.; Ha, C.H.; Chang, H.I. Induction of apoptosis by genipin inhibits cell proliferation in AGS human gastric cancer cells via Egr1/p21 signaling pathway. Bioorg. Med. Chem. Lett. 2015, 25, 4191-4196. [CrossRef]

194. Yang, X.; Yao, J.; Luo, Y.; Han, Y.; Wang, Z.; Du, L. P38 MAP kinase mediates apoptosis after genipin treatment in non-small-cell lung cancer H1299 cells via a mitochondrial apoptotic cascade. J. Pharmacol. Sci. 2013, 121, 272-281. [CrossRef]

195. Lee, M.J.; Hsu, J.D.; Wang, C.J. Inhibition of 12-o-tetradecanoylphorbol-13-acetate-caused tumor promotion in benzo[a]pyreneinitiated CD-1 mouse skin by geniposide. Anticancer Res. 1995, 15, 411-416. [PubMed]

196. Liu, J.H.; Yin, F.; Guo, L.X.; Deng, X.H.; Hu, Y.H. Neuroprotection of geniposide against hydrogen peroxide induced PC12 cells injury: Involvement of PI3 kinase signal pathway. Acta Pharmacol. Sin. 2009, 30, 159-165. [CrossRef] [PubMed]

197. Chao, T.S.O.; Abe, M.; Hershenson, M.B.; Gomes, I.; Rosner, M.R. Thapsigargin Activates Src, Raf-l, and MAP Kinase. Cancer Res. 1997, 57, 3168-3173. [PubMed] 
198. Oryan, A.; Bemani, E.; Bahrami, S. Emerging role of amiodarone and dronedarone, as antiarrhythmic drugs, in treatment of leishmaniasis. Acta Trop. 2018, 185, 34-41. [CrossRef] [PubMed]

199. Sehgal, P.; Szalai, P.; Olesen, C.; Praetorius, H.A.; Nissen, P.; Christensen, S.B.; Engedal, N.; Møller, J.V. Inhibition of the sarco/endoplasmic reticulum (ER) Ca2-ATPase by thapsigargin analogs induces cell death via ER Ca2 depletion and the unfolded protein response. J. Biol. Chem. 2017, 292, 19656-19673. [CrossRef]

200. He, Q.; Lee, D.I.; Rong, R.; Yu, M.; Luo, X.; Klein, M.; El-Deiry, W.S.; Huang, Y.; Hussain, A.; Sheikh, M.S. Endoplasmic reticulum calcium pool depletion-induced apoptosis is coupled with activation of the death receptor 5 pathway. Oncogene 2002, 21, 2623-2633. [CrossRef] [PubMed]

201. Kasaian, J.; Mohammadi, A. Biological activities of farnesiferol C: A review. J. Asian Nat. Prod. Res. 2018, 20, 27-35. [CrossRef]

202. Hasanzadeh, D.; Mahdavi, M.; Dehghan, G.; Charoudeh, H.N. Farnesiferol C induces cell cycle arrest and apoptosis mediated by oxidative stress in MCF-7 cell line. Toxicol. Rep. 2017, 4, 420-426. [CrossRef]

203. Kahraman, H. The Importance of L-Rhamnose Sugar Mini Review. Biomed. J. Tech. Res. 2019, 21, 15906-15908. [CrossRef]

204. Tomsik, P.; Soukup, T.; Cermakova, E.; Micuda, S.; Niang, M.; Sucha, L.; Rezacova, M. L-rhamnose and L-fucose suppress cancer growth in mice. Cent. Eur. J. Biol. 2011, 6, 1-9. [CrossRef]

205. Yau, T.; Dan, X.; Ng, C.C.W.; Ng, T.B. Lectins with potential for anti-cancer therapy. Molecules 2015, 20, 3791-3810. [CrossRef]

206. Cheng, L.; Xia, T.S.; Wang, Y.F.; Zhou, W.; Liang, X.Q.; Xue, J.Q.; Shi, L.; Wang, Y.; Ding, Q. The apoptotic effect of D Rhamnose $\beta$-hederin, a novel oleanane-type triterpenoid saponin on breast cancer cells. PLoS ONE 2014, 9, 90848. [CrossRef] [PubMed]

207. Kitahiro, Y.; Koike, A.; Sonoki, A.; Muto, M.; Ozaki, K.; Shibano, M. Anti-inflammatory activities of Ophiopogonis Radix on hydrogen peroxide-induced cellular senescence of normal human dermal fibroblasts. J. Nat. Med. 2018, 72, 905-914. [CrossRef]

208. Zhang, W.; Zhang, Q.; Jiang, Y.; Li, F.; Xin, H. Effects of ophiopogonin B on the proliferation and apoptosis of SGC-7901 human gastric cancer cells. Mol. Med. Rep. 2016, 13, 4981-4986. [CrossRef]

209. Dong, W.; Dong, Q.; Ding, H. Ophiopogonin B induces reactive oxygen species-dependent apoptosis through the Hippo pathway in nasopharyngeal carcinoma. Mol. Med. Rep. 2021, 24, 534. [CrossRef] [PubMed]

210. Ercolano, G.; De Cicco, P.; Ianaro, A. New drugs from the sea: Pro-apoptotic activity of sponges and algae derived compounds. Mar. Drugs 2019, 17, 31. [CrossRef] [PubMed]

211. Wang, J.; Chen, S.; Xu, S.; Yu, X.; Ma, D.; Hu, X.; Cao, X. In Vivo induction of apoptosis by fucoxanthin, a marine carotenoid, associated with down-regulating STAT3/EGFR signaling in sarcoma 180 (S180) xenografts-bearing mice. Mar. Drugs 2012, 10, 2055-2068. [CrossRef]

212. Rokkaku, T.; Kimura, R.; Ishikawa, C.; Yasumoto, T.; Senba, M.; Kanaya, F.; Mori, N. Anticancer effects of marine carotenoids, fucoxanthin and its deacetylated product, fucoxanthinol, on osteosarcoma. Int. J. Oncol. 2013, 43, 1176-1186. [CrossRef]

213. Takahashi, K.; Hosokawa, M.; Kasajima, H.; Hatanaka, K.; Kudo, K.; Shimoyama, N.; Miyashita, K. Anticancer effects of fucoxanthin and fucoxanthinol on colorectal cancer cell lines and colorectal cancer tissues. Oncol. Lett. 2015, 10, 1463-1467. [CrossRef]

214. Martin, L.J. Fucoxanthin and Its Metabolite Fucoxanthinol in Cancer Prevention and Treatment. Mar. Drugs 2015, 13, 4784-4798. [CrossRef]

215. Yuan, H.; Song, J.; Li, X.; Li, N.; Dai, J. Immunomodulation and antitumor activity of K-carrageenan oligosaccharides. Cancer Lett. 2006, 243, 228-234. [CrossRef]

216. Available online: www.new-ag.info/00-2/focuson/focuson2.html (accessed on 1 October 2021).

217. Lee, V.; Tobey, J.; Castro, K.; Crawford, B. Marine Biodiversity Assets and Threats Assessment Gambia-Senegal Sustainable Fisheries Project; Coastal Resources Center, University of Rhode Island: Kingston, RI, USA, 2009.

218. Necas, J.; Bartosikova, L. Carrageenan: A review. Vet. Med. 2013, 58, 187-205. [CrossRef]

219. Al-Nahdi, Z.M.; Al-Alawi, A.; Al-Marhobi, I. The Effect of Extraction Conditions on Chemical and Thermal Characteristics of Kappa-Carrageenan Extracted from Hypnea bryoides. J. Mar. Biol. 2019, 2019, 1-10. [CrossRef]

220. Prajapati, V.D.; Maheriya, P.M.; Jani, G.K.; Solanki, H.K. Carrageenan: A natural seaweed polysaccharide and its applications. Carbohydr. Polym. 2014, 105, 97-112. [CrossRef] [PubMed]

221. Luo, M.; Shao, B.; Nie, W.; Wei, X.W.; Li, Y.L.; Wang, B.L.; He, Z.Y.; Liang, X.; Ye, T.H.; Wei, Y.Q. Antitumor and Adjuvant Activity of $\lambda$-carrageenan by Stimulating Immune Response in Cancer Immunotherapy. Sci. Rep. 2015, 5, 11062. [CrossRef] [PubMed]

222. Luthuli, S.; Wu, S.; Cheng, Y.; Zheng, X.; Wu, M.; Tong, H. Therapeutic effects of fucoidan: A review on recent studies. Mar. Drugs 2019, 17, 487. [CrossRef]

223. Hsu, H.Y.; Lin, T.Y.; Lu, M.K.; Leng, P.J.; Tsao, S.M.; Wu, Y.C. Fucoidan induces Toll-like receptor 4-regulated reactive oxygen species and promotes endoplasmic reticulum stress-mediated apoptosis in lung cancer. Sci. Rep. 2017, 7, 44990. [CrossRef] [PubMed]

224. Zhang, Z.; Teruya, K.; Eto, H.; Shirahata, S. Induction of apoptosis by low-molecular-weight fucoidan through calcium- and caspase-dependent mitochondrial pathways in MDA-MB-231 breast cancer cells. Biosci. Biotechnol. Biochem. 2013, 77, $235-242$. [CrossRef]

225. Adrian, T.E.; Collin, P. The anti-cancer effects of frondoside A. Mar. Drugs 2018, 16, 64. [CrossRef] [PubMed]

226. Menchinskaya, E.S.; Pislyagin, E.A.; Kovalchyk, S.N.; Davydova, V.N.; Silchenko, A.S.; Avilov, S.A.; Kalinin, V.I.; Aminin, D.L. Antitumor activity of cucumarioside A2-2. Chemotherapy 2014, 59, 181-191. [CrossRef] 
227. Dyshlovoy, S.A.; Menchinskaya, E.S.; Venz, S.; Rast, S.; Amann, K.; Hauschild, J.; Otte, K.; Kalinin, V.I.; Silchenko, A.S.; Avilov, S.A.; et al. The marine triterpene glycoside frondoside A exhibits activity in vitro and in vivo in prostate cancer. Int. J. Cancer 2016, 138, 2450-2465. [CrossRef] [PubMed]

228. Jin, J.O.; Shastina, V.V.; Shin, S.W.; Xu, Q.; Park, J.I.; Rasskazov, V.A.; Avilov, S.A.; Fedorov, S.N.; Stonik, V.A.; Kwak, J.Y. Differential effects of triterpene glycosides, frondoside A and cucumarioside A2-2 isolated from sea cucumbers on caspase activation and apoptosis of human leukemia cells. FEBS Lett. 2009, 583, 697-702. [CrossRef] [PubMed]

229. Janakiram, N.B.; Mohammed, A.; Zhang, Y.; Choi, C.I.; Woodward, C.; Collin, P.; Steele, V.E.; Rao, C.V. Chemopreventive effects of Frondanol A5, a Cucumaria frondosa extract, against rat colon carcinogenesis and inhibition of human colon cancer cell growth. Cancer Prev. Res. 2010, 3, 82-91. [CrossRef]

230. Roginsky, A.B.; Ding, X.Z.; Woodward, C.; Ujiki, M.B.; Singh, B.; Bell, R.H.; Collin, P.; Adrian, T.E. Anti-pancreatic cancer effects of a polar extract from the edible sea cucumber, cucumaria frondosa. Pancreas 2010, 39, 646-652. [CrossRef] [PubMed]

231. Zhao, Q.; Liu, Z.D.; Xue, Y.; Wang, J.F.; Li, H.; Tang, Q.J.; Wang, Y.M.; Dong, P.; Xue, C.H. Ds-echinoside A, a new triterpene glycoside derived from sea cucumber, exhibits antimetastatic activity via the inhibition of NF- $\mathrm{BB}$-dependent MMP-9 and VEGF expressions. J. Zhejiang Univ. Sci. B 2011, 12, 534-544. [CrossRef]

232. Tong, Y.; Zhang, X.; Tian, F.; Yi, Y.; Xu, Q.; Li, L.; Tong, L.; Lin, L.; Ding, J. Philinopside A, a novel marine-derived compound possessing dual anti-angiogenic and anti-tumor effects. Int. J. Cancer 2005, 114, 843-853. [CrossRef]

233. Tian, F.; Zhu, C.H.; Zhang, X.W.; Xie, X.; Xin, X.L.; Yi, Y.H.; Lin, L.P.; Geng, M.Y.; Ding, J. Philinopside E, a new sulfated saponin from sea cucumber, blocks the interaction between kinase insert domain-containing receptor (KDR) and $\alpha \mathrm{v} \beta 3$ integrin via binding to the extracellular domain of KDR. Mol. Pharmacol. 2007, 72, 545-552. [CrossRef]

234. Dinku, W.; Isaksson, J.; Rylandsholm, F.G.; Bouř, P.; Brichtová, E.; Choi, S.U.; Lee, S.H.; Jung, Y.S.; No, Z.S.; Svendsen, J.S.M.; et al. Anti-proliferative activity of a novel tricyclic triterpenoid acid from Commiphora africana resin against four human cancer cell lines. Appl. Biol. Chem. 2020, 63, 1-11. [CrossRef]

235. Zhang, S.L.; Li, L.; Yi, Y.H.; Sun, P. Philinopsides E and F, two new sulfated triterpene glycosides from the sea cucumber Pentacta quadrangularis. Nat. Prod. Res. 2006, 20, 399-407. [CrossRef]

236. Malyarenko, O.S.; Dyshlovoy, S.A.; Kicha, A.A.; Ivanchina, N.V.; Malyarenko, T.V.; Carsten, B.; Gunhild, V.A.; Stonik, V.A.; Ermakova, S.P. The Inhibitory Activity of Luzonicosides from the Starfish Echinaster luzonicus against Human Melanoma Cells. Mar. Drugs 2017, 15, 227. [CrossRef]

237. Fukuoka, K.; Yamagishi, T.; Ichihara, T.; Nakaike, S.; Iguchi, K.; Yamada, Y.; Fukumoto, H.; Yoneda, T.; Samata, K.; Ikeya, H.; et al. Mechanism of action of aragusterol A (YTA0040), a potent anti-tumor marine steroid targeting the G1 phase of the cell cycle. Int. J. Cancer 2000, 88, 810-819. [CrossRef]

238. Wu, S.Y.; Sung, P.J.; Chang, Y.L.; Pan, S.L.; Teng, C.M. Heteronemin, a spongean sesterterpene, induces cell apoptosis and autophagy in human renal carcinoma cells. Biomed. Res. Int. 2015, 2015, 1-14. [CrossRef] [PubMed]

239. Schumacher, M.; Cerella, C.; Eifes, S.; Chateauvieux, S.; Morceau, F.; Jaspars, M.; Dicato, M.; Diederich, M. Heteronemin, a spongean sesterterpene, inhibits TNF $\alpha$-induced NF- $\mathrm{KB}$ activation through proteasome inhibition and induces apoptotic cell death. Biochem. Pharmacol. 2010, 79, 610-622. [CrossRef]

240. Chen, Y.C.; Huang, M.Y.; Zhang, L.L.; Feng, Z.L.; Jiang, X.M.; Yuan, L.W.; Huang, R.Y.; Liu, B.; Yu, H.; Wang, Y.T.; et al. Nagilactone E increases PD-L1 expression through activation of c-Jun in lung cancer cells. Chin. J. Nat. Med. 2020, 18, 517-525. [CrossRef]

241. Zhang, L.L.; Guo, J.; Jiang, X.M.; Chen, X.P.; Wang, Y.T.; Li, A.; Lin, L.G.; Li, H.; Lu, J.J. Identification of nagilactone E as a protein synthesis inhibitor with anticancer activity. Acta Pharmacol. Sin. 2020, 41, 698-705. [CrossRef] [PubMed]

242. Zhang, L.L.; Jiang, X.M.; Huang, M.Y.; Feng, Z.L.; Chen, X.; Wang, Y.; Li, H.; Li, A.; Lin, L.G.; Lu, J.J. Nagilactone E suppresses TGF- $\beta 1$-induced epithelial-mesenchymal transition, migration and invasion in non-small cell lung cancer cells. Phytomedicine 2019, 52, 32-39. [CrossRef]

243. Tang, S.A.; Zhou, Q.; Guo, W.Z.; Qiu, Y.; Wang, R.; Jin, M.; Zhang, W.; Li, K.; Yamori, T.; Dan, S.; et al. In vitro antitumor activity of stellettin B, a triterpene from marine sponge Jaspis stellifera, on human glioblastoma cancer SF295 cells. Mar. Drugs 2014, 12, 4200-4213. [CrossRef]

244. Shrestha, S.; Sorolla, A.; Fromont, J.; Blancafort, P.; Flematti, G.R. Crambescidin 800, isolated from the marine sponge monanchora viridis, induces cell cycle arrest and apoptosis in triple-negative breast cancer cells. Mar. Drugs 2018, 16, 53. [CrossRef]

245. Shin, Y.; Kim, G.D.; Jeon, J.E.; Shin, J.; Lee, S.K. Antimetastatic effect of halichondramide, a trisoxazole macrolide from the marine sponge chondrosia corticata, on human prostate cancer cells via modulation of epithelial-to-mesenchymal transition. Mar. Drugs 2013, 11, 2472-2485. [CrossRef]

246. Bae, S.Y.; Kim, G.D.; Jeon, J.E.; Shin, J.; Lee, S.K. Anti-proliferative effect of (19Z)-halichondramide, a novel marine macrolide isolated from the sponge Chondrosia corticata, is associated with G2/M cell cycle arrest and suppression of mTOR signaling in human lung cancer cells. Toxicol. In Vitro 2013, 27, 694-699. [CrossRef]

247. Suna, H.; Aoki, S.; Setiawan, A.; Kobayashi, M. Crambescidin 800, a pentacyclic guanidine alkaloid, protects a mouse hippocampal cell line against glutamate-induced oxidative stress. J. Nat. Med. 2007, 61, 288-295. [CrossRef]

248. Achenbach, H.; Waibel, R.; Asonka, S.A.; Addae-Mensah, I.; Oppong, I.V. Dichapetalin A, a novel plant constituent from Dichapetalum madagascariense with potential antineoplastic activity. Nat. Prod. Lett. 1995, 7, 93-100. [CrossRef] 
249. Addae-Mensah, I.; Waibel, R.; Asunka, S.A.; Oppong, I.V.; Achenbach, H. The dichapetalins-A new class of triterpenoids. Phytochemistry 1996, 43, 649-656. [CrossRef]

250. Osei-Safo, D.; Chama, M.A.; Addae-Mensah, I.; Waibel, R.; Asomaning, W.A.; Oppong, I.V. Dichapetalin M from Dichapetalum madagascariensis. Phytochem. Lett. 2008, 1, 147-150. [CrossRef]

251. Tuchinda, P.; Kornsakulkarn, J.; Pohmakotr, M.; Kongsaeree, P.; Prabpai, S.; Yoosook, C.; Kasisit, J.; Napaswad, C.; Sophasan, S.; Reutrakul, V. Dichapetalin-type triterpenoids and lignans from the aerial parts of Phyllanthus acutissima. J. Nat. Prod. 2008, 71, 655-663. [CrossRef]

252. Long, C.; Aussagues, Y.; Molinier, N.; Marcourt, L.; Vendier, L.; Samson, A.; Poughon, V.; Mutiso, P.B.C.; Ausseil, F.; Sautel, F.; et al. Dichapetalins from Dichapetalum species and their cytotoxic properties. Phytochemistry 2013, 94, 184-191. [CrossRef] [PubMed]

253. Osei-Safo, D.; Dziwornu, G.A.; Appiah-Opong, R.; Chama, M.A.; Tuffour, I.; Waibel, R.; Amewu, R.; Addae-Mensah, I.; Newman, D.J. Constituents of the Roots of Dichapetalum pallidum and Their Anti-Proliferative Activity. Molecules 2017, $22,532$. [CrossRef]

254. Geng, H.-C.; Zhu, H.-T.; Yang, W.-N.; Wang, D.; Yang, C.-R.; Zhang, Y.-J. New cytotoxic dichapetalins in the leaves of Phyllanthus acidus: Identification, quantitative analysis, and preliminary toxicity assessment. Bioorg. Chem. 2021, 114, 105125. [CrossRef]

255. Blackwell, M. The fungi: 1, 2, 3 ... 5.1 million species? Am. J. Bot. 2011, 98, 426-438. [CrossRef]

256. Jakubczyk, D.; Dussart, F. Selected Fungal Natural Products with Antimicrobial Properties. Molecules 2020, 25, 911. [CrossRef]

257. Arora, R.; Yates, C.; Gary, B.D.; McClellan, S.; Tan, M.; Xi, Y.; Reed, E.; Piazza, G.A.; Owen, L.B.; Dean-Colomb, W. Panepoxydone targets NF- $\mathrm{B}$ and FOXM1 to inhibit proliferation, induce apoptosis and reverse epithelial to mesenchymal transition in breast cancer. PLoS ONE 2014, 9, e98370. [CrossRef] [PubMed]

258. Rether, J.; Erkel, G.; Anke, T.; Sterner, O. Inhibition of inducible TNF- $\alpha$ expression by oxaspirodion, a novel spiro-compound from the ascomycete Chaetomium subspirale. Biol. Chem. 2004, 385, 829-834. [CrossRef]

259. Trisciuoglio, D.; Uranchimeg, B.; Cardellina, J.H.; Meragelman, T.L.; Matsunaga, S.; Fusetani, N.; Del Bufalo, D.; Shoemaker, R.H.; Melillo, G. Induction of apoptosis in human cancer cells by candidaspongiolide, a novel sponge polyketide. J. Natl. Cancer Inst. 2008, 100, 1233-1246. [CrossRef] [PubMed]

260. Whitson, E.L.; Pluchino, K.M.; Hall, M.D.; McMahon, J.B.; McKee, T.C. New candidaspongiolides, tedanolide analogues that selectively inhibit melanoma cell growth. Org. Lett. 2011, 13, 3518-3521. [CrossRef] [PubMed]

261. Yang, T.; Lu, Z.; Meng, L.; Wei, S.; Hong, K.; Zhu, W.; Huang, C. The novel agent ophiobolin O induces apoptosis and cell cycle arrest of MCF-7 cells through activation of MAPK signaling pathways. Bioorg. Med. Chem. Lett. 2012, 22, 579-585. [CrossRef]

262. Lv, C.; Qin, W.; Zhu, T.; Wei, S.; Hong, K.; Zhu, W.; Chen, R.; Huang, C. Ophiobolin O isolated from Aspergillus ustus induces G1 arrest of MCF-7 cells through interaction with AKT/GSK3 $\beta$ /cyclin D1 signaling. Mar. Drugs 2015, 13, 431-443. [CrossRef]

263. Liu, Q.Y.; Zhou, T.; Zhao, Y.Y.; Chen, L.; Gong, M.W.; Xia, Q.W.; Ying, M.G.; Zheng, Q.H.; Zhang, Q.Q. Antitumor effects and related mechanisms of Penicitrinine A, a novel alkaloid with a unique spiro skeleton from the marine fungus Penicillium citrinum. Mar. Drugs 2015, 13, 4733-4753. [CrossRef] [PubMed]

264. Dewangan, J.; Srivastava, S.; Rath, S.K. Salinomycin: A new paradigm in cancer therapy. Tumor Biol. 2017, 39, 1-12. [CrossRef]

265. Kim, K.Y.; Kim, S.H.; Yu, S.N.; Park, S.K.; Choi, H.D.; Yu, H.S.; Ji, J.H.; Seo, Y.K.; Ahn, S.C. Salinomycin enhances doxorubicininduced cytotoxicity in multidrug resistant MCF-7/MDR human breast cancer cells via decreased efflux of doxorubicin. Mol. Med. Rep. 2015, 12, 1898-1904. [CrossRef]

266. Liu, Y.; Hao, Y.; Li, Y.; Zheng, Y.; Dai, J.; Zhong, F.; Wei, W.; Fang, Z. Salinomycin induces autophagic cell death in salinomycinsensitive melanoma cells through inhibition of autophagic flux. Sci. Rep. 2020, 10, 1-14. [CrossRef]

267. Lee, S.J.; Moon, G.S.; Jung, K.H.; Kim, W.J.; Moon, S.K. c-Jun N-terminal kinase 1 is required for cordycepin-mediated induction of G2/M cell-cycle arrest via p21WAF1 expression in human colon cancer cells. Food Chem. Toxicol. 2010, 48, 277-283. [CrossRef] [PubMed]

268. Joo, J.C.; Hwang, J.H.; Jo, E.; Kim, Y.R.; Kim, D.J.; Lee, K.B.; Park, S.J.; Jang, I.S. Cordycepin induces apoptosis by caveolin-1mediated JNK regulation of Foxo3a in human lung adenocarcinoma. Oncotarget 2017, 8, 12211-12224. [CrossRef] [PubMed]

269. Lefranc, F.; Tabanca, N.; Kiss, R. Assessing the anticancer effects associated with food products and/or nutraceuticals using in vitro and in vivo preclinical development-related pharmacological tests. Semin. Cancer Biol. 2017, 46, 14-32. [CrossRef] [PubMed]

270. Eldehna, W.M.; Al-Rashood, S.T.; Al-Warhi, T.; Eskandrani, R.O.; Alharbi, A.; Kerdawy, A.M. El Novel oxindole/benzofuran hybrids as potential dual CDK2/GSK-3 $\beta$ inhibitors targeting breast cancer: Design, synthesis, biological evaluation, and in silico studies. J. Enzyme Inhib. Med. Chem. 2021, 36, 270-285. [CrossRef] [PubMed] 